Development Center

\title{
Feasibility Study of a Qualified Recycling Program at Fort Huachuca, Arizona
}

Dominique S. Gilbert, Stephen D. Cosper, Abigail M. Brake,

September 2018 and Giselle Rodriguez 
The U.S. Army Engineer Research and Development Center (ERDC) solves the nation's toughest engineering and environmental challenges. ERDC develops innovative solutions in civil and military engineering, geospatial sciences, water resources, and environmental sciences for the Army, the Department of Defense, civilian agencies, and our nation's public good. Find out more at www.erdc.usace.army.mil.

To search for other technical reports published by ERDC, visit the ERDC online library at http://acwc.sdp.sirsi.net/client/default. 


\section{Feasibility Study of a Qualified Recycling Program at Fort Huachuca, Arizona}

Dominique S. Gilbert, Stephen D. Cosper, Abigail M. Brake, and Giselle Rodriguez

Construction Engineering Research Laboratory

U.S. Army Engineer Research and Development Center

2902 Newmark Drive

Champaign, IL 61822

Final report

Approved for public release; distribution is unlimited.

Prepared for U.S. Army Garrison

14 Rhea Avenue

Fort Huachuca, AZ 85613-7004

Under P2 Project 454201, "Evaluation of Waste Diversion Opportunities for Fort Huachuca, AZ" 


\section{Abstract}

This document details the processes and procedures that Fort Huachuca, Arizona, must follow to establish a qualified recycling program (QRP). QRP programs help installations meet Army goals to minimize waste disposal costs and increase waste diversion rates. This document will outline three optimizing recycling collection strategies: (1) collection from all buildings, (2) collection by building type, and (3) collection only from specific buildings. In an effort to help Fort Huachuca determine the feasibility of establishing a recycling and QRP program, these scenarios are formulated according to three main recycling and QRP program goals: income, diversion, and a combination of both income and diversion. Each scenario is presented with an economic analysis. Wherever feasible, the QRP is an effective mechanism, and it offers a cost-effective way to use funds from the sale of recyclables to support a recycling program and various morale, welfare, and recreation efforts. 


\section{Abbreviations}

\begin{tabular}{|c|c|}
\hline Term & Meaning \\
\hline AAFES & Army and Air Force Exchange Service \\
\hline APF & appropriated funds \\
\hline AR & Army Regulation \\
\hline ASP & ammunition supply point \\
\hline C\&D & construction and demolition \\
\hline CDC & Child Development Center \\
\hline CFC & chlorofluorocarbon \\
\hline CFR & Code of Federal Regulations \\
\hline COF & Company Operational Facility \\
\hline $\mathrm{DD}$ & Directives Division \\
\hline DeCA & Defense Commissary Agency \\
\hline DEMIL & demilitarization \\
\hline DFAC & dining facilities \\
\hline DFAS & Defense Finance and Accounting Services \\
\hline DFMWR & Directorate of Family Morale, Welfare, and Recreation \\
\hline DLA & Defense Logistics Agency \\
\hline DOC & Distribution Operations Center \\
\hline DoD & Department of Defense \\
\hline DoDACC & DoD Activity Address Code \\
\hline DoDI & Department of Defense Instruction \\
\hline $\mathrm{DOL}$ & Directorate of Logistics \\
\hline DPW & Directorate of Public Works \\
\hline DTID & Disposal Turn-In Document \\
\hline EO & Executive Order \\
\hline EOCD & expanded shell ordinance casings deformer \\
\hline EPG & Electronic Proving Ground \\
\hline ERDC-CERL & $\begin{array}{l}\text { Engineer Research and Development Center-Construction } \\
\text { Engineering Research Laboratory }\end{array}$ \\
\hline FMWR & Family and Morale, Welfare, and Recreation (Directorate) \\
\hline FOG & fats, oils, grease \\
\hline FY & fiscal year \\
\hline GC & Garrison Commander \\
\hline GIB & general information building \\
\hline GOCO & government owned/contractor operated \\
\hline
\end{tabular}




\begin{tabular}{|c|c|}
\hline Term & Meaning \\
\hline GPW & general purpose warehouse \\
\hline HQDA & Headquarters Department of the Army \\
\hline IMARC & Installation Management Application Resource Center \\
\hline IMCOM & Installation Management Command \\
\hline ISWM & Installation Solid Waste Management \\
\hline ISWMP & Installation Solid Waste Management Program \\
\hline JITC & Joint Interoperability Test Command \\
\hline LCC & life-cycle cost \\
\hline LOA & Letter of Agreement \\
\hline MARS & Military Affiliate Radio System \\
\hline MDAS & material documented as safe \\
\hline MFH & Military Family Housing \\
\hline MOU & memorandum of understanding \\
\hline MPPEH & Material Potentially Presenting an Explosive Hazard \\
\hline NAF & nonappropriated funds \\
\hline NETCOM & Network Enterprise Technology Command \\
\hline $\mathrm{NH}$ & nonhazardous \\
\hline $\mathrm{OHC}$ & Outpatient Health Center \\
\hline OC & Oversight Committee \\
\hline OCC & old corrugated cardboard \\
\hline PAO & Public Affairs Office \\
\hline PFF & physical fitness facility \\
\hline POC & point of contact \\
\hline PWS & performance work statement \\
\hline PX & Post Exchange \\
\hline QASAS & Quality Ammunition and Surveillance Assurance Specialist \\
\hline QRP & qualified recycling program \\
\hline QRP-OC & QRP Oversight Committee \\
\hline $\mathrm{RCl}$ & Residential Communities Initiative \\
\hline RCRA & Resource Conservation and Recovery Act \\
\hline RMO & Resource Management Office \\
\hline ROI & return on investment \\
\hline SF & Standard Form \\
\hline SJA & Staff Judge Advocate \\
\hline SOP & standard operating procedures \\
\hline SWAR & Solid Waste Annual Reporting \\
\hline
\end{tabular}




\begin{tabular}{|l|l|}
\hline Term & Meaning \\
\hline SWARWeb & web-based SWAR data management system \\
\hline TDY & temporary duty \\
\hline TEMF & tactical equipment maintenance facility \\
\hline UEPH & Unaccompanied Enlisted Personnel Housing \\
\hline USAICoE & U.S. Army Intelligence Center of Excellence \\
\hline U.S.C. & United States Code \\
\hline WC & waste characterization \\
\hline WCF & working capital fund \\
\hline
\end{tabular}




\section{Contents}

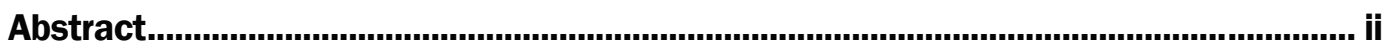

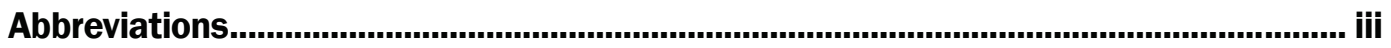

Figures and Tables.....................................................................................................................viii

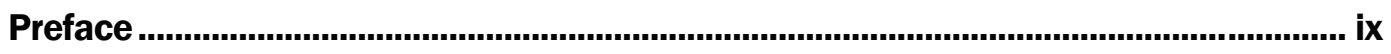

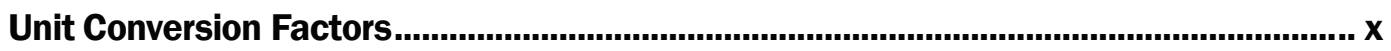

1 Introduction to a Qualified Recycling Program ......................................................

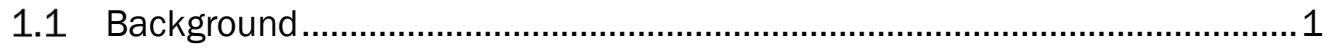

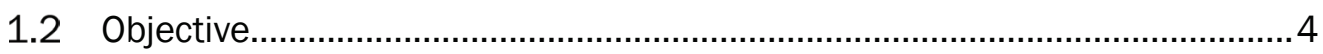

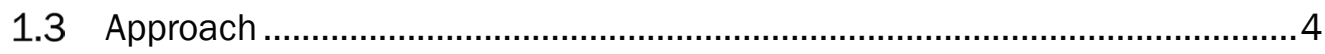

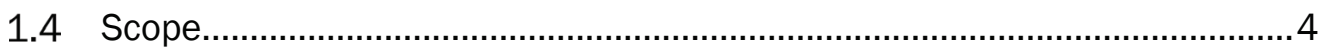

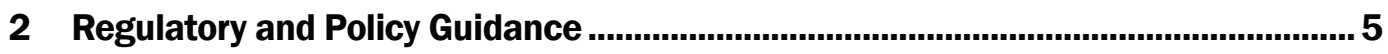

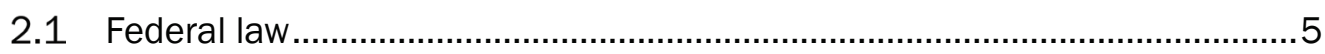

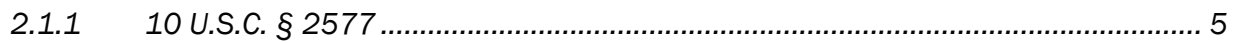

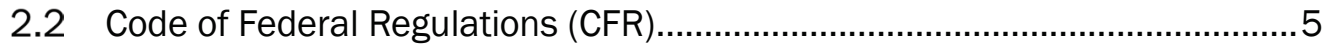

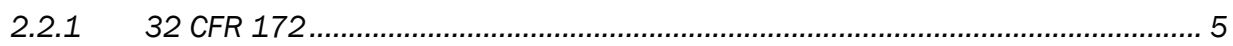

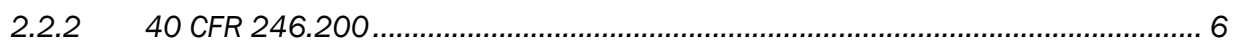

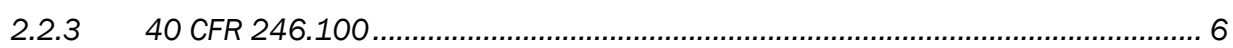

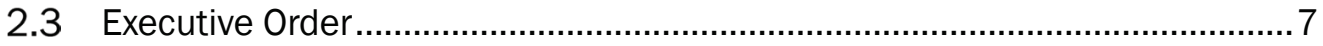

2.4 Department of Defense Instruction.............................................................. 7

2.5 Army Regulation..................................................................................... 7

2.5.1 AR 420-1 (2012) - Army Facilities Management .............................................. 7

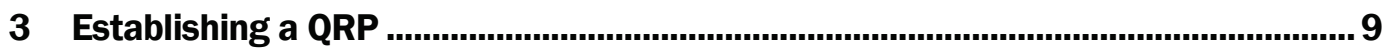

3.1 Step 1: Establish feasibility of a QRP ....................................................... 9

3.2 Step 2: Prepare a memo that states the GC wants to have a QRP..............10

3.3 Step 3: Establish a suspense account for depositing QRP funds ................10

3.4 Step 4: Determine whether to conduct direct sales or partner with

DLA to sell materials..........................................................................................10

3.5 Step 5: Prepare documents explaining program operations and

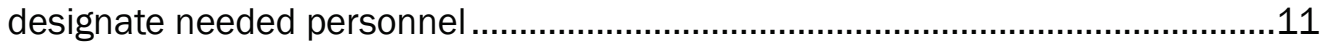

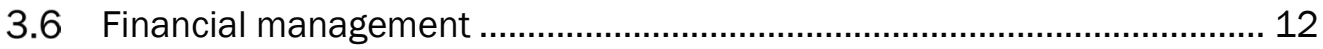

3.7 Records management and reporting ................................................... 12

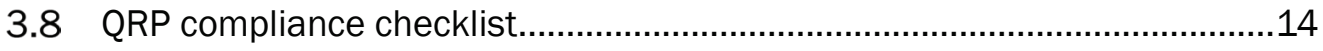

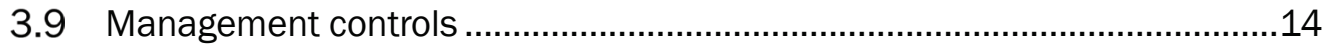

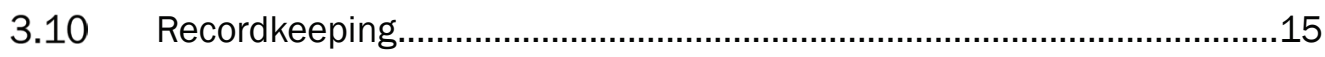

3.11 Responsibilities of Garrison Commander ............................................16

3.12 Responsibilities of DPW Director.............................................................16

3.13 Responsibilities of QRP Manager ...................................................19 


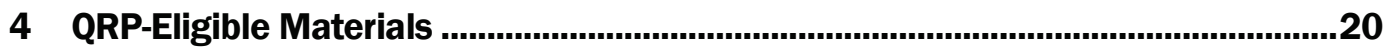

5 Recycling Potential at Fort Huachuca...................................................................27

5.1 Overview of recyclable materials generated at Fort Huachuca .................... 28

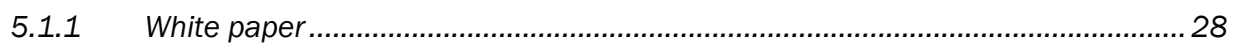

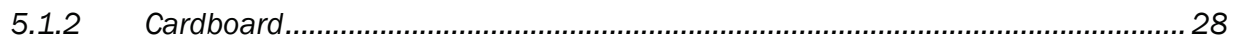

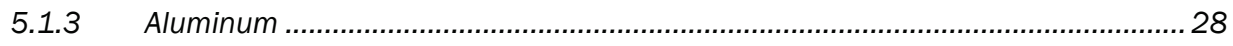

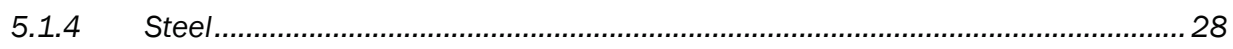

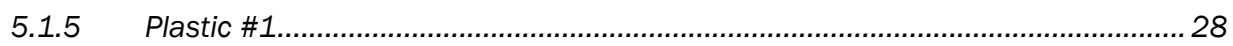

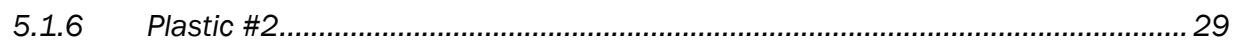

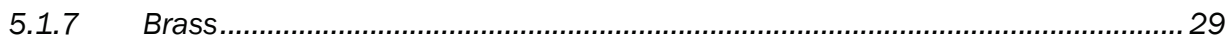

5.2 Recommended recyclable materials ......................................................... 29

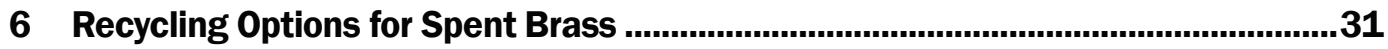

6.1 Option 1: Brass sales through DLA..................................................... 31

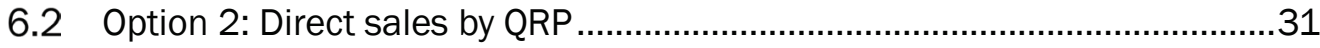

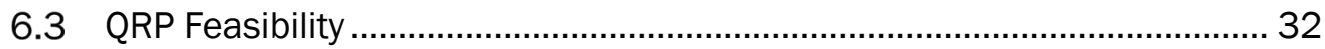

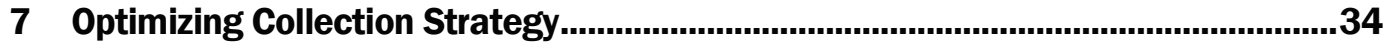

7.1 Scenario \#1: Collection from all buildings ................................................. 34

7.2 Scenario \#2: Recyclable collection by building type ................................... 39

7.3 Scenario \#3: Collection from specific buildings ...................................... 41

8 Summary: Costs and Benefits of Three Scenarios for a QRP .................................44

8.1 Economic evaluation, with scenarios ..................................................... 44

8.2 Summary of scenario advantages and disadvantages ............................. 46

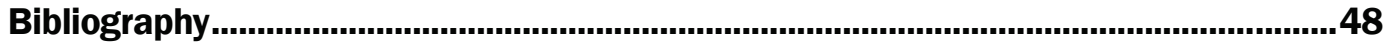

APPENDIX A: General Method for Recyclable Material Projection ..............................50

Report Documentation Page 


\section{Figures and Tables}

\section{Figures}

Figure 1. Example of recycling container that could be used at Fort Huachuca (priced at GSA Advantage).

Figure 2. Example exterior container for cardboard (manufactured by Global Industrial).

Figure 3. Example interior recycling bin (manufactured by Grainger).

\section{Tables}

Table 1. Materials disposition and diversion eligibility guidance (from DoDI 4715.23).

Table 2. Installation-wide recyclable generation and costs (ERDC-CERL)

Table 3. Expended brass turn-in data for Fort Huachuca (source: Supply and

Services Division, Logistics Readiness Center, Fort Huachuca). 29

Table 4. Suggested recyclables to collect at Fort Huachuca (ERDC-CERL). .30

Table 5. Projected ROI for brass direct sales (ERDC-CERL).

Table 6. Suggested recycling container exterior locations (ERDC-CERL).

Table 7. Cost of recycling containers according to the recommended number of interior and exterior containers based on building type and size (ERDC-CERL, 2017).

Table 8. Total value of recyclables (ERDC-CERL)

Table 9. Annual recyclable generation amounts at Fort Huachuca for all buildings by building type (ERDC-CERL). 39

Table 10. Recyclable values generated per year by building type (ERDC-CERL)

Table 11. Top 25 buildings for project recyclable generation (ton/year) (ERDCCERL).

Table 12. Projected market value of recyclables at the top-producing buildings (ERDC-CERL).

Table 13. ROI summary for collection scenarios (ERDC-CERL).

Table 14. Recycling collection pros and cons, compared by scenario (ERDC- 


\section{Preface}

This study was conducted for U.S. Army Garrison Fort Huachuca under P2 Project Number 454201, "Evaluation of Waste Diversion Opportunities for Fort Huachuca, AZ.” The sponsor's technical monitor was Mr. Jack Porter, Fort Huachuca.

The work was performed by the Environmental Processes Branch of the Installation Division (CEERD-CNE), U.S. Army Engineer Research and Development Center, Construction Engineering Research Laboratory (ERDC-CERL). At the time of publication, Mr. H. Garth Anderson was Chief, CEERD-CNE; Ms. Michelle Hanson was Chief, CEERD-CN; and Mr. Kurt Kinnevan, CEERD-CZT, was the Technical Director for Infrastructure for Combat Operations. The Deputy Director of ERDC-CERL was Dr. Kirankumar Topudurti, and the Director was Dr. Lance D. Hansen.

The Commander of ERDC was COL Ivan P. Beckman, and the Director was Dr. David W. Pittman. 


\section{Unit Conversion Factors}

\begin{tabular}{|l|c|l|}
\hline Multiply & By & To Obtain \\
\hline gallons (U.S. liquid) & $3.785412 \mathrm{E}-03$ & cubic meters \\
\hline pounds (mass) & 0.45359237 & kilograms \\
\hline pounds (force) per square foot & 47.88026 & Pascals \\
\hline square feet & 0.09290304 & square meters \\
\hline tons (2,000 pounds, mass) & 907.1847 & kilograms \\
\hline yards & 0.9144 & meters \\
\hline
\end{tabular}




\section{Introduction to a Qualified Recycling Program}

This document considers the feasibility of establishing a qualified recycling program (QRP) at Fort Huachuca, Arizona. Fort Huachuca is located in the southeastern corner of Arizona, at the northern end of the Huachuca Mountains, and near the town of Sierra Vista. It is the home of the U.S. Army Intelligence Center of Excellence (USAICoE) and the U.S. Army Network Enterprise Technology Command (NETCOM)/9th Army Signal Command. It is also the headquarters of Army Military Affiliate Radio System (MARS), the Joint Interoperability Test Command (JITC), and the Electronic Proving Ground (EPG).

Fort Huachuca is interested in implementing recycling and investigating the viability of starting a QRP. To that end, this document presents the results of a study of the feasibility and operating parameters for a QRP at Fort Huachuca.

\subsection{Background}

A QRP can be a cost-effective way for installations to support their recycling efforts. Several installations annually generate over $\$ 1$ million in proceeds by selling their recycling products. These installations are able to translate their successful QRP programs into financial benefits, in general for recycling programs and in particular for supporting an installation's Family and Morale, Welfare, and Recreation (FMWR) efforts. Installations like Fort Hood, Joint Base Lewis-McChord, and Fort Carson are some of the many examples of Army installations that maintain sustainable, profitable, and long-lasting QRPs.

The U.S. Armed Forces defines a QRP in the U.S. Code (U.S.C.) as "organized operations that require concerted efforts to divert or recover scrap or waste, as well as efforts to identify, segregate, and maintain the integrity of 
the recyclable materials in order to maintain or enhance their marketability..." ${ }^{\text {Th }}$ This means that the QRP must follow a specified process and provide accountability for all materials in the program and for all funds received and/or expended for QRP operations. The QRP is the mechanism that allows the installation to receive funds from the sale of recyclables. The installation QRP must work with all host and tenant organizations on post, including those in leased space. Contracts covering government owned/contractor operated (GOCO) facilities should include opportunities for a contractor to participate in a QRP.

Under 10 U.S.C. 2577 and consistent with Department of Defense (DoD) financial management regulation 7000.14-R, ${ }^{2}$ a QRP shall use sales proceeds from recyclables for only three purposes, listed below in priority order:

1. Cost of recycling programs. "...to cover the costs of operations, maintenance, and overhead for processing recyclable materials at the installation (including the cost of any equipment purchased for recycling purposes);" "...and if a balance remains, then:

2. Installation pollution abatement. "...not more than $50 \%$ of that balance may be used at the installation for projects for pollution abatement, energy conservation, and occupational safety and health activities. A project may not be carried out under the preceding sentence for an amount greater than $50 \%$ of the amount established by law as the maximum amount for a minor construction project...”

3. FMWR accounts. "...the remaining balance available to a military installation may be transferred to the non-appropriated morale and welfare account of the installation to be used for any morale or welfare activity."

As stated, QRP proceeds may only be used for the purposes listed above. At the end of the fiscal year, any QRP account balance over \$2,000,000 will revert to the U.S. Treasury. In short, the revenues realized from the sale of recyclables must be adequate to support the recycling program, but

110 U.S.C. 2577, “Armed Forces - Disposal of Recyclable Materials” (Washington, DC: U.S. Armed Forces in U.S. Code, 2006 Edition, Suppl. 4, Title 10, 2006).

2 DoD Financial Management Regulation (FMR) 700.14-R, “Reimbursable Operations Policy,” Volume 11a of Department of Defense Financial Management Regulation, (Washington, DC: Under Secretary of Defense - Comptroller, 2014). 
excess funds can be used to support other initiatives like expanding recycling services and environmental efforts and, as stated above, up to 50\% of sales proceeds can target FMWR efforts. QRP funds may NOT be used for appropriated fund labor or program start-up costs.

It is important to note that QRP funds are no-year funds, meaning that installations can maintain a running balance in the QRP account that extends across fiscal years, up to $\$ 2,000,000$.

While economic feasibility is the main goal for QRP operations, waste diversion is also an important objective; the recent Executive Order (EO) $13834^{3}$ (2018) orders federal agencies to minimize waste and to pursue cost-effective waste disposal measures as part of meeting federal sustainability goals. In some regions of the country where hauling rates and tipping fees are especially expensive, the avoidance costs alone (i.e., the costs that are avoided by recycling rather than landfilling) can make recycling economically feasible.

QRPs may be operated by the Directorate of Public Works (DPW) or nonappropriated funds (NAF) activities such as Directorate of Family Morale, Welfare, and Recreation (DFMWR). Although Army installations cannot establish more than one QRP on post, a regional QRP may provide services to more than one installation. 4

However, even if it is determined that establishing a QRP is cost-prohibitive, Army Regulation (AR) 200-15 requires recycling when mandated by state or local regulations pursuant to AR 420-49. ${ }^{6}$ Furthermore, CFR 246.200-1 requires that high-grade paper generated by offices with over

\footnotetext{
3 EO 13834, Efficient Federal Operations (Washington, DC: U.S. President Donald J. Trump, 17 May 2018).

410 U.S.C. 2577, "Armed Forces - Disposal of Recyclable Materials."

5 AR 200-1, Environmental Protection and Enhancement (Washington, DC: U.S. Army Assistant Secretary of the Army, 21 February 1997 [updated 2007]).

6 AR 420-49, Utility Services (Washington, DC: U.S. Army, Heritage and Education Center, 19 September 2005 [rev.]).
} 
100 workers shall be collected, separated at the source, and sold for recycling. 7 For office facilities of less than 100 office workers, the recycling of high-grade paper should be implemented wherever feasible.

At Fort Huachuca, a QRP could be a potential mechanism to allow the installation to receive funds from the sale of its recyclables. Furthermore, a QRP at Fort Huachuca would offer cost savings by diverting waste materials from landfill to recycling, thus reducing hauling costs and tipping fees to landfill the materials.

\subsection{Objective}

The objective of this research was to explore the feasibility of establishing a QRP on Fort Huachuca and to review the different waste management efforts that would make a QRP profitable.

\subsection{Approach}

This work was performed in the following steps:

1. In July 2015, the CERL waste team performed a waste characterization. Waste characterization findings were detailed in a waste characterization study reported to Installation Management Command (IMCOM) in 2016.

2. Those waste characterization findings were used herein to determine the feasibility of a QRP at Fort Huachuca.

3. The QRP feasibility results were determined (Section 6.3), as were optimized waste collection strategies (Chapter 7) and a summary of cost and benefits per each of three scenarios (Chapter 8).

\subsection{Scope}

Although this work was undertaken to determine the feasibility of a QRP at Fort Huachuca, the methods to determine the cost/benefit and optimization of waste collection strategies may apply broadly at many DoD facilities throughout the continental United States.

\footnotetext{
740 CFR 246.200-1, “High-Grade Paper Recovery, Requirements," in Title 40 (Protection of Environment), Chapter I (EPA), Subchapter I (Solid Wastes), Part 246 (Source Separation for Materials Recovery Guidelines), Subpart B (Requirements and Recommended Procedures. (Washington, DC: U.S. Environmental Protection Agency, 41 Federal Register 16952, 23 April 1976).
} 


\section{Regulatory and Policy Guidance}

The requirements for QRPs within the DoD are based on statutes, regulations, EOs, Department of Defense Instruction (DoDI), and Army policies. The Resource Conservation and Recovery Act of 1976 (RCRA) ${ }^{8}$ and a number of EOs have also emphasized waste diversion and recycling. All the policy agendas behind these various documents are to focus federal efforts on recycling and waste prevention. The following sections detail the federal, DoD, and Army regulations that apply to QRP operations and management of related funds.

\subsection{Federal law}

\subsubsection{U.S.C. $\$ 2577^{9}$}

- Subsection (a)(1) maintains that the Secretary of Defense will prescribe regulations for the sale of recyclable materials at military departments or defense agencies and for the operation of recycling programs at military installations.

- Subsection (b)(1) outlines how a QRP is to use sales proceeds from recyclables, as described in section 1 above.

\subsection{Code of Federal Regulations (CFR)}

\subsubsection{CFR $172^{10}$}

- Subsection (3)(b) explains that amounts collected by the DoD for the sale of excess and surplus property shall be deposited promptly to the U.S. Treasury accounts.

- Subsections (c)(1), (c)(2), and (c)(3) also discuss QRP use of sales proceeds from recyclables, as mentioned above.

\footnotetext{
8 Resource and Recovery Act of 1976, Public Law (P.L.) 94-580 (Washington, DC: 94th United States Congress and President Gerald Ford, 1976).

910 U.S.C. §2577, “Armed Forces - Disposal of Recyclable Materials."

1032 CFR 172. Title 32 (National Defense) Subtitle A (Department of Defense) Part 172, Disposition of Proceeds from DoD Sales of Surplus Property, Published at 54 Federal Register 35483. (Washington, DC: Department of Defense, 2011).
} 


\subsection{2 $\quad 40$ CFR 246.20011}

- Section 246.200-1 ("Requirements") states that high-grade paper recovery generated by office facilities with over 100 office workers shall be separated at the source of generation, separately collected, and sold for the purpose of recycling.

- Section 246.200-2 ("Recommended procedures: High-grade paper recovery") states that high-grade paper recovery generated by office facilities of less than 100 office workers should be implemented where markets make it feasible.

- Section 246.202-1 ("Requirement") says that corrugated container recovery from commercial establishments generating 10 or more tons of corrugated container waste per month shall separately collect and sell this material for the purpose of recycling.

- Section 246.202-2 ("Recommended procedures: corrugated container recovery") says that corrugated container recovery from commercial facilities generating less than 10 tons per month should be implemented where markets make it feasible.

\subsubsection{CFR 246.10012}

- CFR 246.100 (f) explains that federal agencies that decide not to source separate shall make available the analysis and rationale used in making that determination. Federal agencies can decide not to source separate if the inability to sell is due to lack of market, and costs are so high as to render source separation for materials recovery economically impracticable.

\footnotetext{
1140 CFR 246.200, “High-Grade Paper Recovery," in Title 40 (Protection of Environment), Chapter I (EPA), Subchapter I (Solid Wastes), Part 246 (Source Separation for Materials Recovery Guidelines), Subpart B (Requirements and Recommended Procedures. (Washington, DC: U.S. Environmental Protection Agency, 41 Federal Register 16952, 23 April 1976).

1240 CFR 246.100, Protection of Environment (Title 40), Environmental Protection Agency (Chapter 1) Source Separation for Materials Recovery Guidelines (Part 246), General Provisions (Subpart A), Scope (§ 246.100). (41 Federal Register 16952, 23 April 1976).
} 


\subsection{Executive Order}

Executive Order (EO) 13834, Efficient Federal Operations, orders federal agencies to adopt methods for increased efficiency, including minimizing waste and pursuing cost-effective waste disposal measures as part of meeting federal sustainability goals.

\subsection{Department of Defense Instruction}

DoDI 4715.23, Integrated Recycling and Solid Waste Management, ${ }^{13}$ establishes responsibilities and outlines procedures for integrated solid waste management (ISWM) through waste prevention and recycling. Section 4 of this instruction outlines the operations, procedural requirements, and financial management necessary to run a QRP. It explains the type of commodity market and economic feasibility analysis that should be pursued as well as the type of training necessary to manage a QRP. Finally, it lists items that are ineligible for a QRP.

\subsection{Army Regulation}

\subsubsection{AR 420-1 (2012) - Army Facilities Management ${ }^{14}$}

- Chapter 23-4, "Responsibilities." Ensures that installations collect and report utility services operating data, to include electrical, heating, natural gas, potable water, wastewater, solid waste and recycling, in the prescribed reporting systems.

- 23-11 - Solid waste reduction, resource recovery, re-use and recycling, and composting practices. Discusses ways to reduce, recover, reuse and recycle. However, subsection (f) makes direct reference to QRPs and states that Installation Management Command (IMCOM) will ensure the implementation of a QRP, where life-cycle cost (LCC) effective. It also says that installations with several recycling programs will incorporate them into a single garrison QRP. Exceptions are those organizations with activities operating under special funding categories, such as commissaries, post exchanges, and working capital or industrial funds,

\footnotetext{
13 DoDI 4715.23, Integrated Recycling and Solid Waste Management (Washington, DC: Office of the Under Secretary of Defense for Acquisition, Technology, and Logistics, 24 October 2016).

14 AR 420-1, Army Facilities Management, Facilities Engineering (Washington, DC: Headquarters Department of the Army, 12 February 2008, Rapid Action Revision 2012).
} 
as these may have separate recycling programs, or they may donate their recyclables to the installation QRP.

- 23-15- Solid waste reporting. Addresses the policies with respect to the reporting of solid waste disposal. 


\section{Establishing a QRP}

There are five main steps to setting up a QRP, as listed below:

1. Establish feasibility of a QRP.

2. Prepare a memo stating the Garrison Commander (GC) wants a QRP.

3. Establish a suspense account for depositing QRP funds.

4. Determine whether to conduct direct sales or partner with Defense Logistics Agency (DLA) Disposition Services to sell materials.

5. Prepare documents explaining program operations.

\subsection{Step 1: Establish feasibility of a QRP}

This step determines whether there is enough recycling potential to warrant a QRP. This step requires a baseline knowledge of the component parts of the waste stream. This knowledge is best achieved with a waste characterization (WC) study that will detail types and quantities of recyclables generated at each individual building as well as installation-wide. Based on the WC results, a determination then can be made as to which tenant organizations generate the most recyclables. Note that researchers at the Engineer Research and Development Center-Construction Engineering Research Laboratory (ERDC-CERL) performed a WC study with the DPW at Fort Huachuca in 2015 and reported the results to the U.S. Army IMCOM in June 2016 (see Chapter 5 for a summary).

After a WC study, a market analysis should be conducted to determine whether it is cost effective for the installation to recycle and to establish a QRP. The market analysis should include an estimate of the revenues for each type of recyclable as well as all processing costs. For this effort, it is important to determine cost-benefits for the different outsourcing alternatives. Specifically, the market analysis should identify potential customers for each recyclable material, determine quality and quantity specifications for each recyclable, as well as look into potential transportation agreements, prices that buyers will pay, and the willingness of buyers to sign at guaranteed minimum prices. Chapter 8 of this report (p 44) explores different cost-benefit scenarios for establishing a QRP at Fort Huachuca. 


\subsection{Step 2: Prepare a memo that states the GC wants to have a QRP.}

The GC must endorse a written recycling policy/regulation that includes all aspects of the recycling program.

\subsection{Step 3: Establish a suspense account for depositing QRP funds}

Establish a 3875 suspense account for depositing proceeds of sales from recyclable materials. This is done through the Resource Management Office (RMO). Next, the local DLA must be notified by memorandum that a QRP and an F3875 suspense account have been established. The memorandum must mention how the QRP and the DLA will work together to properly handle materials. Memorandum topics should include procedures for notifying and redirecting materials that accidentally end up in the QRP waste stream, such as usable or reusable items, items purchased with appropriated funds (APF), or Munitions List items turned in to the QRP by mistake. Similarly, authorized QRP items (see Chapter 4) such as aluminum cans or fired brass-that should have been processed and sold by the QRP - could have been sent inadvertently to the DLA. In this case, the DLA chief should inform the QRP that some QRP-eligible items were sent to the DLA, so the revenue from their sale can be properly credited to the QRP suspense account.

\subsection{Step 4: Determine whether to conduct direct sales or partner with DLA to sell materials}

The GC decides whether to conduct direct sales or partner with DLA to sell materials. (DoDI 4715.23 gives each military service the authority to grant direct sales authority to installation commanders.)

If the GC decides in favor of direct sales, then the GC must sign a letter of authorization and send it to Army IMCOM.

If the GC decides to go through the DLA, then the GC must acquire a letter of authorization establishing the agreement that QRP sales are to go through DLA. If deciding to go through DLA, then Release/Receipt Document, Directives Division (DD) Form 1348-1A, Disposal Turn-In Document (DTID) must be used. 


\subsection{Step 5: Prepare documents explaining program operations and designate needed personnel}

After steps \#1-4 have been completed, certain procedures must be performed and certain documents prepared. The following points outline protocols for how the program will run.

- The GC has to sign off on the choice of QRP Manager. The QRP Manager is usually either a person in the DPW and/or someone under the Environmental Division.

- The GC must establish a QRP Oversight Committee (QRP-OC) to establish procedures for the distribution of QRP sales proceeds after program operational costs have been covered and in accordance with 10 U.S.C. 2577.

- A QRP Business Plan must be prepared. It will include the feasibility study and waste stream analysis. The plan will identify the available resources and potential markets along with facility, equipment, and vehicle requirements. It should include the standard operating procedures (SOP), support the Installation Solid Waste Management Program (ISWMP), detail the QRP management goals, and disclose whether the installation will conduct direct sales or work with the DLA. If it is decided the QRP will conduct direct sales, then a standalone SOP specifically for QRP operations should be developed.

To ensure that QRP processes operate as intended and resources are safeguarded from fraud, waste, and misuse, the person responsible for selling the recyclable materials should not be the same person who is responsible for receiving, recording, and depositing the funds received from sales. However, if local circumstances prevent such separation from being established within the QRP, then management must establish and use appropriate oversight mechanisms from elsewhere on the installation to ensure that individuals do not misuse or abuse their assigned authority.

Step 5 also includes detailed financial management, records management, and reporting efforts. Financial management efforts are explained in the sections that follow. 


\subsection{Financial management}

The following points comprise QRP financial management requirements:

- Make sure that QRP transactions shall be on a non-cash basis.

- Establish QRP direct sales abilities.

- Determine the QRP operating budget.

- Establish procedures for depositing proceeds into the F3875 Budget Clearing Account (Suspense) with Defense Finance and Accounting Services (DFAS).

- Make sure QRP sales proceeds are allocated to the QOC in accordance with 10 U.S.C. 2577.

- Determine whether the QRP Manager will negotiate direct sales agreements and whether those agreements will exceed $\$ 15,000$.

- Determine whether the QRP Manager will conduct commodity sales and also collect sales proceeds.

- Establish that sales proceeds will be payable to the U.S. Treasury and deposited by a government employee who is not the QRP Manager.

\subsection{Records management and reporting}

Establish a management control system that will assure the program meets its goals and properly accounts for government resources. The management control process should emphasize prevention of waste, fraud, and mismanagement and the timely correction of management control weaknesses. This system should be integrated into daily management practices. Several techniques to employ in the management control program are listed below. See Army internal controls guidance in AR 11-2 ${ }^{15}$ for additional information.

\footnotetext{
15 AR 11-2, Army Managers' Internal Control Program (Washington, DC: Headquarters, Department of the Army, 4 January 2010).
} 
- Develop an accounting and tracking program that will detail recyclable materials and QRP cash flow.

- Know contractor/tenant reporting requirements.

- Implement recycling material segregation policies for all recyclable materials and detail policies in contracts like a performance work statement (PWS).

- If sales will go through the DLA, then it is important to establish DLA disposition services turn-in procedures.

- Conduct regular (quarterly) recycling opportunity assessments for all recyclable commodities.

- Evaluate and/or monitor on a quarterly basis all recycling practices including procedures for storage, collection, segregation, and transportation as well as final disposition.

- If the GC decides to run recycling revenues through DLA instead of operating a direct sales QRP, then turn-in procedures must be provided using DD Form 1348-1A.

- Establish a recycling policy.

- The SOP should detail all processes performed at the QRP and cover the following:

- Designation of a QRP Manager and duties of other installation staff offices that will support recycling.

- Types of materials handled and how they will be recycled.

○ Specific implementation procedures.

- Mechanisms for tracking and maintaining records of the types and amounts of materials handled.

- Mechanism for tracking and maintaining accounting records of funds received and disbursed. 
- Payment/transfer of operating expenses.

- Distribution of amounts remaining in the installation recycling account for authorized purposes.

\subsection{QRP compliance checklist}

After the QRP is set up, the following documentation must be maintained to comply with IMCOM policy:

- Recycling Policy: Installation policy that outlines recycling efforts.

- QRP SOP: Provides details on program procedures.

- QRP Business Plan: Provides comprehensive details and plans.

- Feasibility Study: Evaluates the economic feasibilities of operating a QRP.

- Market Analysis: Determines the financial benefits and/or losses associated with each eligible material.

- Waste Stream Analysis: Establishes the Installation's waste stream baseline and identifies recyclable materials.

- Facility/Building Representatives: List of QRP staff and/or points of contact (POCs) at recycling center.

- QRP- Operating or Oversight Committee (OC) Charter: Defines purpose, structure, and requirements of QRP-OC.

- QRP Manager Appointment Letter: QRPs must have an appointed program manager.

- DLA Letter of Agreement (LOA): Establishes that DLA will use the QRP LOA and the DoD Activity Address Code (DODAAC) for QRP eligible turn-ins.

\subsection{Management controls}

The following are the required management controls: 
- Internal Audits: Required annually to review all QRP-related files, processes, and accounting.

- External Audits: Required every three years to review all QRP-related files, processes, and accounting.

- Management Control Reviews: Provides assurance that the QRP program meets its goals and properly accounts for government resources.

- Excluded Item Sales Controls: Must be in place to ensure only eligible materials are accepted and sold via the QRP.

- Protocols: Establish protocols that prevent the QRP from collecting recyclable materials that are prohibited by the Army or DoD regulations.

\subsection{Recordkeeping}

The following items comprise the required recordkeeping:

- QRP Subcommittee Meeting Minutes: Document past working group level meetings.

- QRP-OC Meeting Minutes: Document QRP-OC meetings.

- Annual Budget and Fund Disbursements: Documents decisions supporting use of proceeds by the QRP-OC or GC.

- List of Buyers: Lists the vetted buyers with which the QRP can do direct sales.

- Maintenance Records: Details facility maintenance costs, including equipment expenditures.

- Training/Certification: Acquired by taking QRP Management Courses.

- Operating and Overhead Costs: Record of operating costs including equipment purchases, labor, training, publicity, maintenance, and program operation.

- Cost Avoidance: Shows monetary savings in terms of weight/volume of material diverted from the waste stream. 
- Retention of Records: Sales Documentation (DD Form 1348-1A) and sales receipts (Standard Form [SF] 1080s), which are required to maintain records for current fiscal year (FY) and two preceding FYs.

\subsection{Responsibilities of Garrison Commander}

The GC is tasked with doing the follow things:

- Designating a QRP Manager who has a good understanding of solid waste management, the recycling industry, materials recycled on post, contract administration, the rules and regulations associated with QRP recycling, the role of DLA, and budgeting. This person should also be able to account for all costs and revenues, be able to manage equipment and employees, and have a good understanding of all associated safety measures. Finally, (if pursuing direct sales of brass) the QRP Manager should have training on Material Potentially Presenting an Explosive Hazard (MPPEH) to ensure that improper materials are not sold when recycling fired brass and gleanings from firing ranges.

- Designating a QOC and a person to chair the QOC, which should meet quarterly. The primary objective of the committee is to advise the GC on program decisions, such as recycling program changes, facility improvements and equipment purchases, and excess recycling fund disbursements.

- The QOC should consist of the QRP Manager, the installation executive officer, and a representative from each of the installation organizations mentioned here, including the RMO, Distribution Operations Center (DOC), DPW, Directorate of Logistics (DOL) Environmental Department management, Staff Judge Advocate (SJA), Safety Office, Public Affairs Office (PAO), Supply, Directorate of FMWR, Family Housing, DLA, tenant activity representatives, and the fire department.

- The QOC is responsible for establishing objectives to maximize recycling and minimize solid waste disposal.

\subsection{Responsibilities of DPW Director}

The DPW's director is the functional manager for the ISWMP and does the following tasks: 
- Plans collection, transportation, storing, and processing of recyclable materials.

- Champions the inclusion of provisions for green procurement and recycling in construction and demolition (C\&D) (including renovations and remodeling) contracts.

- Develops and administers contracts that support the QRP, as directed by the Director of Contracting.

- Reports solid waste management data, including QRP data and tenant recycling data, to Headquarters Department of the Army (HQDA) using the web-based Solid Waste Annual Reporting (SWAR) data management system (SWARWeb).

- Acquires solid waste and recycling equipment.

- Supervises QRP operations, which include doing the following tasks:

- Ensure that recycling revenues are used in accordance with 10 U.S.C. 2577.

- Maintain the required accounting records.

- Provide support for the documentation of all proceeds received from sales of recyclable materials and for the disbursement of funds for authorized purposes.

○ Ensure excluded materials are not sold through the QRP. 
- Track and maintain records of quantities of recyclables sold and revenues gained from sales, including SWARWeb reporting, ${ }^{16}$ and in accordance with the Army's Qualified Recycling Program Handbook. ${ }^{17}$

○ Procure equipment for QRP operations.

- Perform personnel management functions and proper training for QRP employees.

○ Develop QRP SOPs, including safety procedures.

- Maintain an active education and promotion program.

- Monitor participation in the QRP.

- Maintain a list of contacts from each building or activity to assist in coordinating the QRP.

○ Address customer complaints.

- Perform annual program reviews, including cost-benefit analyses.

- Advise the GC on QRP status.

\footnotetext{
16 SWARWeb Reporting (paragraph 8.8 from the Qualified Recycling Program Handbook [see footnote below): SWARWEB is the official Army system for collecting solid waste and recycling information. Installations are required to report all solid waste and recycling activity on a semi-annual basis through the chain of command to HQDA, using the Solid Waste Annual Report, Web-based (SWARWeb). Reports are due within 45 days after the end of the second and fourth quarters of the fiscal year. Managers of new construction, major renovation, facilities reduction or other demolition projects shall also report C\&D waste activities to the designated installation Point of Contact for data entry to SWARWeb. Annual evaluation of an installation or activity's success, rated against the Department of Defense Pollution Prevention and Compliance Metrics, will be on the overall performance (total tons of recycled or diverted waste divided by the total tons of waste generated multiplied by 100) attained throughout the reporting period, as determined from the data reported in SWARWeb located at https://www.acsimapps.army.mil.

The SWARWeb is accessible via the Installation Management Application Resource Center (IMARC) portal at https://www.acsim-apps.army.mil. User ID requests from installations are subject to approval by HQDA.

17 U.S. Army, Qualified Recycling Program Handbook (Washington, DC: U.S. Army Headquarters, Assistant Chief of Staff Installation Management [ACSIM], November 2010).
} 


\subsection{Responsibilities of QRP Manager}

The QRP Manager is in charge of the following tasks:

- Maintaining all QRP direct sales records as well as all financial records from the inception of the QRP, including all operating, overhead, equipment, start-up costs, and financial avoidance records. The direct sales information should include item descriptions, sales price, payment date, weight of scrap sold, and sale dates.

- $\quad$ Retaining DLA Disposition Services records - which include the disposal turn-in documents (DD Form 1348-1A), ${ }^{18}$ sales receipts (SF 1080), ${ }^{19}$ and copies of payment checks for funds transfers.

- Reporting diversion metrics through SWARWeb. The SWARWeb is accessible via the Installation Management Application Resource Center (IMARC) portal. ${ }^{20}$ The QRP will provide recycling information and data to the installation SWARWeb point of contact. The types of information that must be reported are material quantities, estimated costs, and cost avoidance.

- Making sure that solid waste (including materials separated for recycling) is stored such that it does not constitute a fire, health or safety hazard, or provide food or harborage for vectors, and is contained or bundled so as not to result in spillage.

- Recycling all federally mandated materials (e.g., newsprint, high-grade paper, and cardboard), where applicable.

\footnotetext{
18 Issue Release/Receipt Document

19 Voucher for Transfers Between Appropriations and/or Funds

20 IMARC portal, https://www.acsim-apps.army.mil/
} 


\section{QRP-Eligible Materials}

As mentioned in previous sections, not all recyclables are eligible for reimbursement under a QRP. DoDI 4715.23 presented an updated list of materials that are QRP-eligible, along with clarification on diversion criteria. Table 1 is an excerpt of information in the DoDI, and it presents materials and their classifications, and whether they are "DLA Disposition Services Eligible" and/or "Diversion metric eligible." The label "DLA Disposition Services Eligible" refers to items that either may be or must be disposed through DLA. These items may or may not be QRP-eligible. On the other hand, "Diversion metric eligible" are items counted as diversion when they are diverted from a landfill. As of 2017, the overall DoD diversion goal is to divert $50 \%$ of solid waste generated. Based on this guidance, recyclable materials considered QRP eligible at Fort Huachuca would include old corrugated cardboard; paper and mixed paper; plastics \#1-7; aluminum; fats, oils, and grease (FOG); scrap metal; and spent brass from ammunition 0.50 caliber and lower.

The QRP can accept materials from most military and civilian garrison activities and tenants. Exceptions include the following:

- Defense Commissary Agency (DeCA) and Army and Air Force Exchange Service (AAFES). Recyclable materials from DeCA Commissaries and AAFES establishments are potentially QRP eligible but only if there is a memorandum of understanding (MOU) stating that recyclables and sales proceeds are being donated to the QRP. As of 2015, the Commissary and Post Exchange (PX) at Fort Huachuca had their own recycling programs. Here is an opportunity for cooperation with the Garrison.

- Privatized Housing under the Residential Communities Initiative (RCI). In order to process recyclable materials from RCI housing through the QRP, there must be an agreement in place between the private housing manager and the installation QRP management. However, this agreement is optional, as the two parties are not obligated to work together and RCI housing recyclable materials are not required to be processed through the QRP. As of 2015, RCI housing at Fort Huachuca has an arrangement with the City of Sierra Vista for recycling collection. 
A general rule of thumb is that if the installation's DPW currently pays for solid waste collection, then recyclables in that collection can go to the QRP and count toward that installation's diversion goals.

Table 1. Materials disposition and diversion eligibility guidance (from DoDI 4715.23).

\begin{tabular}{|c|c|c|c|c|}
\hline Item & $\begin{array}{l}\text { QRP } \\
\text { Eligible }\end{array}$ & $\begin{array}{l}\text { DLA } \\
\text { Disposition } \\
\text { Services } \\
\text { Eligible }\end{array}$ & $\begin{array}{l}\text { Diversion } \\
\text { Metric Eligible }\end{array}$ & Notes \\
\hline High-grade office paper & Yes & Yes & Yes & \\
\hline Mixed office paper & Yes & Yes & Yes & \\
\hline Newspaper print & Yes & Yes & Yes & \\
\hline Corrugated cardboard & Yes & Yes & Yes & \\
\hline $\begin{array}{l}\text { Corrugated cardboard } \\
\text { generated by } \\
\text { commissaries or } \\
\text { exchanges }\end{array}$ & Yes* & Yes & Yes & $\begin{array}{l}\text { *QRP eligible only if a } \\
\text { memorandum of } \\
\text { understanding (MOU) is in } \\
\text { effect with the local } \\
\text { commissary or exchange } \\
\text { stating they are donating } \\
\text { the cardboard and any } \\
\text { sales proceeds to the QRP } \\
\text { QRPs cannot return } \\
\text { proceeds to commissaries } \\
\text { or exchanges. }\end{array}$ \\
\hline $\begin{array}{l}\text { Plastics (recycling } \\
\text { codes } 1-7 \text { ) }\end{array}$ & Yes & Yes & Yes & \\
\hline Glass & Yes & Yes & Yes & \\
\hline $\begin{array}{l}\text { Aluminum and other } \\
\text { metal cans }\end{array}$ & Yes & Yes & Yes & \\
\hline $\begin{array}{l}\text { Ferrous and nonferrous } \\
\text { scrap metal }\end{array}$ & Yes & Yes & Yes & From other activities. \\
\hline $\begin{array}{l}\text { Scrap metal from } \\
\text { DEMIL of ships, } \\
\text { aircraft, or weapons }\end{array}$ & No & Yes & No & \\
\hline
\end{tabular}




\begin{tabular}{|c|c|c|c|c|}
\hline Item & $\begin{array}{l}\text { QRP } \\
\text { Eligible }\end{array}$ & $\begin{array}{l}\text { DLA } \\
\text { Disposition } \\
\text { Services } \\
\text { Eligible }\end{array}$ & $\begin{array}{l}\text { Diversion } \\
\text { Metric Eligible }\end{array}$ & Notes \\
\hline $\begin{array}{l}\text { Scrap metal generated } \\
\text { from activities } \\
\text { supported by the } \\
\text { working capital fund } \\
\text { (WCF) }\end{array}$ & No & Yes & Yes & \\
\hline $\begin{array}{l}\text { Unserviceable } \\
\text { appliances in scrap } \\
\text { condition }\end{array}$ & Yes & Yes & Yes & $\begin{array}{l}\text { Refrigerants must be } \\
\text { recovered from } \\
\text { refrigerators and air- } \\
\text { conditioner units before } \\
\text { sale. Chlorofluorocarbon } \\
\text { (CFC) refrigerants should } \\
\text { be turned in to the DLA } \\
\text { Ozone Depleting } \\
\text { Substance Reserve. }\end{array}$ \\
\hline $\begin{array}{l}\text { Expended small arms } \\
\text { cartridge casings } \\
\text { (ESACCs); .50 caliber } \\
\text { (12.7 mm and smaller }\end{array}$ & Yes & Yes & Yes & $\begin{array}{l}\text { Options: (1) QRP must } \\
\text { deform casings before } \\
\text { direct sale, or (2) turn in to } \\
\text { DLA Disposition Services } \\
\text { with properly documented } \\
\text { DD Form } 1348-1 A 1 \text { to } \\
\text { receive sales proceeds. }\end{array}$ \\
\hline $\begin{array}{l}\text { Expended casings } \\
\text { larger than } .50 \text { caliber } \\
(12.7 \mathrm{~mm})\end{array}$ & No & Yes & Yes & $\begin{array}{l}\text { Requires safety } \\
\text { inspections and } \\
\text { Demilitarization (DEMIL) } \\
\text { (Code G items). }\end{array}$ \\
\hline $\begin{array}{l}\text { Mixed metal range } \\
\text { gleanings }\end{array}$ & Yes & Yes & Yes & \\
\hline $\begin{array}{l}\text { Ammunition cans and } \\
\text { boxes; scrap condition, } \\
\text { unusable or } \\
\text { unserviceable } .50 \\
\text { caliber }(12.7 \mathrm{~mm}) \text { and } \\
\text { smaller }\end{array}$ & Yes & Yes & Yes & \\
\hline $\begin{array}{l}\text { Ammunition cans and } \\
\text { boxes; serviceable for } \\
\text { intended use }\end{array}$ & No & Yes & Yes & \\
\hline
\end{tabular}




\begin{tabular}{|c|c|c|c|c|}
\hline Item & $\begin{array}{l}\text { QRP } \\
\text { Eligible }\end{array}$ & $\begin{array}{l}\text { DLA } \\
\text { Disposition } \\
\text { Services } \\
\text { Eligible }\end{array}$ & $\begin{array}{l}\text { Diversion } \\
\text { Metric Eligible }\end{array}$ & Notes \\
\hline $\begin{array}{l}\text { Precious-metal bearing } \\
\text { scrap }\end{array}$ & No & Yes & No & \\
\hline $\begin{array}{l}\text { Wooden pallets; } \\
\text { unusable or } \\
\text { unserviceable }\end{array}$ & Yes & No & Yes & \\
\hline Wooden pallets; usable & No* & Yes & Yes & $\begin{array}{l}\text { *QRP-eligible only with site- } \\
\text { by-site DLA Disposition } \\
\text { Services documented } \\
\text { approval to determine as } \\
\text { scrap. }\end{array}$ \\
\hline Scrap wood & Yes & Yes & Yes & \\
\hline Landscape trimmings & Yes & Yes & Yes* & $\begin{array}{l}\text { * Grass clippings left in } \\
\text { place is waste avoidance } \\
\text { and not eligible for } \\
\text { diversion credit. If collected } \\
\text { and composted, include as } \\
\text { diversion. }\end{array}$ \\
\hline Food waste & Yes & No & Yes & \\
\hline Excess food, donated & No & No & Yes & \\
\hline $\begin{array}{l}\text { Scrap furniture; broken, } \\
\text { non- repairable, } \\
\text { unusable, or } \\
\text { unserviceable }\end{array}$ & Yes* & Yes & Yes & $\begin{array}{l}\text { *QRP must sell as scrap } \\
\text { metal, wood, or textile; } \\
\text { cannot sell as usable } \\
\text { furniture item. QRP must } \\
\text { retain on file DLA } \\
\text { Disposition Services } \\
\text { abandonment or } \\
\text { destruction certification. }\end{array}$ \\
\hline Used furniture & No & Yes & Yes & \\
\hline $\begin{array}{l}\text { Uncontaminated rags } \\
\text { and textiles }\end{array}$ & Yes & Yes & Yes & \\
\hline
\end{tabular}




\begin{tabular}{|c|c|c|c|c|}
\hline Item & $\begin{array}{l}\text { QRP } \\
\text { Eligible }\end{array}$ & $\begin{array}{l}\text { DLA } \\
\text { Disposition } \\
\text { Services } \\
\text { Eligible }\end{array}$ & $\begin{array}{l}\text { Diversion } \\
\text { Metric Eligible }\end{array}$ & Notes \\
\hline Cooking oil or grease & Yes & Yes & Yes* & $\begin{array}{l}\text { *If used for waste-to- } \\
\text { energy purposes, it is } \\
\text { disposal, not diversion. }\end{array}$ \\
\hline $\begin{array}{l}\text { Used vehicle oil; non- } \\
\text { hazardous (NH) }\end{array}$ & Yes & Yes & Yes* & $\begin{array}{l}\text { *If used for waste-to- } \\
\text { energy purposes, it is } \\
\text { disposal, not diversion. }\end{array}$ \\
\hline $\begin{array}{l}\text { Used vehicle oil; } \\
\text { Resource Conservation } \\
\text { and Recovery Act } \\
\text { hazardous }\end{array}$ & No & Yes & No & \\
\hline $\begin{array}{l}\text { Antifreeze; NH ethylene } \\
\text { glycol- based }\end{array}$ & Yes & Yes & Yes & \\
\hline Fuel sources & No & Yes & No & $\begin{array}{l}\text { As defined in Section } 2922 \mathrm{e} \\
\text { of Title 10, U.S.C. }\end{array}$ \\
\hline $\begin{array}{l}\text { Unopened containers of } \\
\text { solvents, paints, or oil } \\
\text { including expired and } \\
\text { NH items }\end{array}$ & No & Yes & No & \\
\hline $\begin{array}{l}\text { Used tires; automotive } \\
\text { and light truck }\end{array}$ & Yes & Yes & Yes* & $\begin{array}{l}\text { *If used for waste-to- } \\
\text { energy purposes, it is } \\
\text { disposal, not diversion. }\end{array}$ \\
\hline Used tires; aircraft & No & Yes & Yes* & $\begin{array}{l}\text { *If recycled (not burned for } \\
\text { waste- to-energy), it is } \\
\text { considered diversion. }\end{array}$ \\
\hline Fluorescent bulbs & Yes & Yes & No* & $\begin{array}{l}\text { * Regulated as universal } \\
\text { waste under federal } \\
\text { regulations. }\end{array}$ \\
\hline $\begin{array}{l}\text { Compact fluorescent } \\
\text { bulbs }\end{array}$ & Yes & Yes & No* & $\begin{array}{l}\text { * Regulated as universal } \\
\text { waste under federal } \\
\text { regulations. }\end{array}$ \\
\hline
\end{tabular}




\begin{tabular}{|c|c|c|c|c|}
\hline Item & $\begin{array}{l}\text { QRP } \\
\text { Eligible }\end{array}$ & $\begin{array}{l}\text { DLA } \\
\text { Disposition } \\
\text { Services } \\
\text { Eligible }\end{array}$ & $\begin{array}{l}\text { Diversion } \\
\text { Metric Eligible }\end{array}$ & Notes \\
\hline Lead-acid batteries & Yes & Yes & No* & $\begin{array}{l}\text { * Regulated as universal } \\
\text { waste under federal } \\
\text { regulations. }\end{array}$ \\
\hline $\begin{array}{l}\text { Government-purchased } \\
\text { cell phone batteries } \\
\text { (lithium-ion } \\
\text { (rechargeable)) }\end{array}$ & No & Yes & No* & $\begin{array}{l}\text { * Regulated as universal } \\
\text { waste under federal } \\
\text { regulations. }\end{array}$ \\
\hline $\begin{array}{l}\text { Dry-cell batteries } \\
\text { (includes: alkaline (non- } \\
\text { rechargeable), carbon } \\
\text { zinc (non-rechargeable), } \\
\text { nickel cadmium } \\
\text { (rechargeable), lithium } \\
\text { (non-rechargeable), and } \\
\text { lithium-ion } \\
\text { (rechargeable)) }\end{array}$ & Yes* & Yes & Yes* & $\begin{array}{l}\text { *If } \mathrm{NH} \text { and non-universal } \\
\text { waste. }\end{array}$ \\
\hline Spent toner cartridges & Yes & Yes & Yes & \\
\hline $\begin{array}{l}\text { Government-purchased } \\
\text { cell phones }\end{array}$ & No & Yes & No & \\
\hline $\begin{array}{l}\text { Materials from building } \\
\text { or structure } \\
\text { deconstruction (copper } \\
\text { wiring, unpainted wood } \\
\text { waste, intact building } \\
\text { components such as } \\
\text { doors and windows) }\end{array}$ & Yes & Yes* & Yes** & $\begin{array}{l}\text { *DLA Disposition Services } \\
\text { does not accept broken } \\
\text { window or glass. } \\
{ }^{*} \text { Reportable as disposed } \\
\text { or diverted C\&D debris. }\end{array}$ \\
\hline $\begin{array}{l}\text { Materials from road or } \\
\text { runway deconstruction } \\
\text { (asphalt, concrete, } \\
\text { metal rebar) }\end{array}$ & Yes & No* & Yes** & $\begin{array}{l}\text { *DLA Disposition Services } \\
\text { accepts metal rebar only } \\
\text { when it is obtained from } \\
\text { road or runway debris. } \\
{ }^{*} \text { Reportable as disposed } \\
\text { or diverted C\&D debris. }\end{array}$ \\
\hline
\end{tabular}




\begin{tabular}{|c|c|c|c|c|}
\hline Item & $\begin{array}{l}\text { QRP } \\
\text { Eligible }\end{array}$ & $\begin{array}{l}\text { DLA } \\
\text { Disposition } \\
\text { Services } \\
\text { Eligible }\end{array}$ & $\begin{array}{l}\text { Diversion } \\
\text { Metric Eligible }\end{array}$ & Notes \\
\hline $\begin{array}{l}\text { Government-purchased } \\
\text { electronic components } \\
\text { (includes information } \\
\text { technology) }\end{array}$ & No & Yes & No & \\
\hline $\begin{array}{l}\text { Privately owned } \\
\text { personal property; lost, } \\
\text { abandoned, or } \\
\text { unclaimed }\end{array}$ & No & Yes & No & \\
\hline $\begin{array}{l}\text { Privately owned } \\
\text { personal property, } \\
\text { donated for QRP } \\
\text { disposal }\end{array}$ & Yes & No & No & \\
\hline $\begin{array}{l}\text { Nonappropriated fund } \\
\text { (NAF) scrap or } \\
\text { recyclables }\end{array}$ & Yes* & Yes & Yes* & $\begin{array}{l}\text { *QRP eligible only when } \\
\text { MOU with local commissary } \\
\text { or exchange states the NAF } \\
\text { is donating both the scrap } \\
\text { items and sales revenue to } \\
\text { the QRP. }\end{array}$ \\
\hline $\begin{array}{l}\text { Privatized MFH } \\
\text { municipal solid waste }\end{array}$ & Yes* & No & Yes** & $\begin{array}{l}\text { *Privatized Military Family } \\
\text { Housing (MFH)-generated } \\
\text { recyclables are QRP eligible, } \\
\text { but not mandatory. QRP } \\
\text { manager should review } \\
\text { contract between privatized } \\
\text { MFH management and the } \\
\text { DoD Component for } \\
\text { options to include reporting } \\
\text { privatized MFH recyclables. } \\
\text { **If QRP is processing } \\
\text { privatized MFH recyclables } \\
\text { and including them as an } \\
\text { installation diversion, both } \\
\text { disposal and diverted } \\
\text { tonnages must be reported. }\end{array}$ \\
\hline
\end{tabular}




\section{Recycling Potential at Fort Huachuca}

Currently, Fort Huachuca does not recycle (other than family housing and some tenants). However, based on the 2015 WC performed by the ERDCCERL Waste Team and reported to IMCOM in 2016, Fort Huachuca generates a number of materials in its waste stream that are QRP eligible. As of August 2017, the brass generated at Fort Huachuca is handled by the DLA based in Tucson, Arizona. For a list of the highest value recyclable materials generated at Fort Huachuca and for projections of recyclable generation rates, installation-wide, see Table 2. Table 2 also provides market values for recyclable materials, their approximate collection costs (based on the waste hauling contract), and net annual values.

Table 2. Installation-wide recyclable generation and costs (ERDC-CERL).

\begin{tabular}{|c|c|c|c|c|c|}
\hline Material Type & $\begin{array}{l}\text { Amount } \\
\text { Generated } \\
\text { (Tons/Year) }\end{array}$ & $\begin{array}{l}\text { Market Value } \\
\text { (\$/Ton) }\end{array}$ & $\begin{array}{l}\text { Total Market } \\
\text { Value ( } \$ / \text { Year) }\end{array}$ & $\begin{array}{l}\text { Estimated } \\
\text { Collection Cost } \\
\text { (@ \$35/Ton) }\end{array}$ & $\begin{array}{l}\text { Potential Net } \\
\text { Value ** }\end{array}$ \\
\hline Plastic \#1 (baled) & 216 & $\$ 160$ & $\$ 34,560$ & $\$ 7,560$ & $\$ 27,000$ \\
\hline $\begin{array}{l}\text { Plastic \#2 (baled, } \\
\text { pigmented) }\end{array}$ & 58 & $\$ 260$ & $\$ 15,080$ & $\$ 2,030$ & $\$ 13,050$ \\
\hline Aluminum (baled) & 78 & $\$ 700$ & $\$ 54,600$ & $\$ 2,730$ & $\$ 51,870$ \\
\hline Brass & 6 & $\$ 3,500$ & $\$ 21,470$ & $\$ 210 *$ & $\$ 21,260$ \\
\hline Cardboard (baled) & 450 & $\$ 77$ & $\$ 34,731$ & $\$ 15,750$ & $\$ 18,981$ \\
\hline Mixed paper (baled) & 48 & $\$ 100$ & $\$ 4,800$ & $\$ 1,680$ & $\$ 3,120$ \\
\hline Newspaper (baled) & 49 & $\$ 18$ & $\$ 927$ & $\$ 1,715$ & $-\$ 787$ \\
\hline Steel & 95 & $\$ 50$ & $\$ 4,750$ & $\$ 3,325$ & $\$ 1,425$ \\
\hline White paper (baled) & 463 & $\$ 120$ & $\$ 55,560$ & $\$ 16,205$ & $\$ 39,355$ \\
\hline Total & 1,463 & & $\$ 226,009$ & $\$ 51,205$ & $\$ 175,274$ \\
\hline
\end{tabular}

* Source: Supply and Services Division, Logistics Readiness Center, Fort Huachuca. See Section 6 of this report for a detailed discussion of brass recycling costs and benefits.

* Potential Net Value $=$ market value minus collection cost 


\subsection{Overview of recyclable materials generated at Fort Huachuca}

The recyclable materials and quantities shown in Table 2 are an accounting of the high-value recyclables at Fort Huachuca. Old corrugated cardboard, white paper, aluminum, steel, plastics \#1-7, and brass are all recyclable materials that are generated at Fort Huachuca, however.

\subsubsection{White paper}

White paper (at 32\%) represented the largest quantity of the high-value recyclables generated per year on the installation. By recycling white paper and diverting it from landfill, the installation could gain an estimated $\$ 27 \mathrm{k}$ more per year. Please refer to 40 CFR 226.200 highlights in subsection 2.2.2 of this report for more specific guidelines on recycling paper.

\subsubsection{Cardboard}

Cardboard represented the second-largest quantity (31\%) of the high-value recyclables generated at Fort Huachuca per year. Since Fort Huachuca generates approximately 450 tons of cardboard each year, the installation must recycle cardboard in order to remain compliant with federal code 32 CFR 246.202-1 (see subsection 2.2.2 of this report). Cardboard recycling at Fort Huachuca is expected to generate close to $\$ 19 \mathrm{k}$ per year.

\subsubsection{Aluminum}

Aluminum was found to make up approximately $5 \cdot 3 \%$ of the high-value materials found in the solid waste stream each year installation-wide. While this percentage may seem low, the 2017 market value for aluminum ranges from $\$ 600-\$ 700$ per ton. Aluminum recycling could provide the installation with an estimated $\$ 44 \mathrm{k}-\$ 52 \mathrm{k}$ of additional funds per year.

\subsubsection{Steel}

Steel comprised approximately $6.5 \%$ of the high-value materials generated per year in the solid waste stream. Recycling steel can gain an estimated $\$ 1,425$ each year for the installation.

\subsubsection{Plastic \#1}

Approximately $15 \%$ of the high-value recyclables generated per year at Fort Huachuca is \#1 Plastic. This material represents the third-largest 
quantity of high-value recyclables found in the installation's solid waste stream. Recycling \#1 plastics could provide approximately $\$ 27 \mathrm{~K}$ of additional funds each year.

\subsubsection{Plastic \#2}

Plastic \# 2 represented close to $4 \%$ of the high valued recyclables generated at Fort Huachuca per year. If recycled and diverted from landfill, this recyclable could provide approximately $\$ 13 \mathrm{~K}$ each year for the QRP.

\subsubsection{Brass}

Table 3 presents pounds of expended brass generated at Fort Huachuca for FY2012-FY2016. Because brass is a high-value commodity, Fort Huachuca can generate a modest income for a QRP from brass sales. In November 2017, the average price for scrap brass was $\$ 1.49$ per pound. ${ }^{21}$ Based on 2017 brass prices, Fort Huachuca's QRP could have received close to $\$ 76,000$ for sales of $51,000 \mathrm{lb}$ of brass that accumulated over the five-year period (FY2012-FY2016).

Table 3. Expended brass turn-in data for Fort Huachuca (source: Supply and Services Division, Logistics Readiness Center, Fort Huachuca).

\begin{tabular}{|l|r|r|r|r|r|r|}
\hline \multirow{3}{*}{ Fiscal Year } & \multicolumn{6}{|c|}{ Expended Brass Turn-in per Type of Shell Casing (Ib) } \\
\cline { 2 - 8 } & $\begin{array}{c}\mathbf{5 0} \\
\text { caliber }\end{array}$ & $\begin{array}{c}5.56 \\
\mathrm{~mm}\end{array}$ & $\begin{array}{c}5.56 \mathrm{~mm} \\
\text { blank }\end{array}$ & $\mathbf{9} \mathrm{mm}$ & $\begin{array}{c}7.62 \\
\mathrm{~mm}\end{array}$ & $\begin{array}{c}\text { Annual } \\
\text { Total }\end{array}$ \\
\hline 2012 & 1,660 & 13,960 & 4,080 & 0 & 0 & 19,700 \\
\hline 2013 & 0 & 3,940 & 0 & 0 & 0 & 3,940 \\
\hline 2014 & 0 & 10,820 & 2,280 & 0 & 0 & 13,100 \\
\hline 2015 & 2,120 & 6,540 & 0 & 3,680 & 0 & 12,340 \\
\hline 2016 & $*$ & $*$ & $*$ & $*$ & 1,920 & 1,920 \\
\hline
\end{tabular}

*Indicates some shell-size data is not available.

\subsection{Recommended recyclable materials}

Given federal recycling policies, quantities generated at Fort Huachuca, and market values, it makes sense for Fort Huachuca to focus recycling efforts on white paper (mandatory under certain parameters, see Subsection

\footnotetext{
21 www.recycleinme.com, accessed November 2017. RecyclelnMe is a leading online scrap trading portal deal with $200+$ sorts of metal and scraps.
} 
2.2.2), cardboard (mandatory under certain parameters, see Section 2.2), mixed paper, aluminum cans, steel cans, \#1 and \#2 plastics, and brass. Table 4 shows the recommended materials to collect and their values.

Table 4. Suggested recyclables to collect at Fort Huachuca (ERDC-CERL).

\begin{tabular}{|c|c|c|c|c|c|}
\hline Material Type & $\begin{array}{l}\text { Amount } \\
\text { Generated at } \\
\text { Fort Huachuca } \\
\text { (tons/year) }\end{array}$ & $\begin{array}{l}\text { Market Value } \\
\text { (\$/ton) }\end{array}$ & $\begin{array}{l}\text { Total Market } \\
\text { Value (\$/year) }\end{array}$ & $\begin{array}{l}\text { Estimated } \\
\text { Collection Cost } \\
\text { (@ \$35/ton) }\end{array}$ & $\begin{array}{l}\text { Potential } \\
\text { Net Revenue }\end{array}$ \\
\hline $\begin{array}{l}\text { Plastic \#1 } \\
\text { (baled) }\end{array}$ & 216 & $\$ 160$ & $\$ 34,560$ & $\$ 7,560$ & $\$ 27,000$ \\
\hline $\begin{array}{l}\text { Plastic \#2 } \\
\text { (baled, } \\
\text { pigmented) }\end{array}$ & 58 & $\$ 260$ & $\$ 15,080$ & $\$ 2,030$ & $\$ 13,050$ \\
\hline $\begin{array}{l}\text { Aluminum } \\
\text { (baled) }\end{array}$ & 78 & $\$ 700$ & $\$ 54,600$ & $\$ 2,730$ & $\$ 51,870$ \\
\hline Brass & 6 & $\$ 3,500$ & $\$ 21,470$ & $\$ 210$ & $\$ 21,260$ \\
\hline $\begin{array}{l}\text { Cardboard } \\
\text { (baled) }\end{array}$ & 450 & $\$ 77$ & $\$ 34,731$ & $\$ 15,750$ & $\$ 18,981$ \\
\hline $\begin{array}{l}\text { Mixed paper } \\
\text { (baled) }\end{array}$ & 48 & $\$ 100$ & $\$ 4,800$ & $\$ 1,680$ & $\$ 3,120$ \\
\hline Steel & 95 & $\$ 50$ & $\$ 4,750$ & $\$ 3,325$ & $\$ 1,425$ \\
\hline $\begin{array}{l}\text { White paper } \\
\text { (baled) }\end{array}$ & 463 & $\$ 120$ & $\$ 55,560$ & $\$ 16,205$ & $\$ 39,355$ \\
\hline Totals & 1414 & - & $\$ 225,081$ & $\$ 49,490$ & $\$ 176,061$ \\
\hline
\end{tabular}




\section{Recycling Options for Spent Brass}

As discussed above, spent brass from .50 caliber and lower shells is QRP eligible, but because all spent brass is considered MPPEH, it must be prepared for sale according to specific guidelines. Thus, it must be inspected by a person trained to certify brass as "material documented as safe" (MDAS). Once deemed MDAS, the brass is ready for transfer either to DLA or to a QRP for direct sales. Brass intended for direct sales must be crushed or deformed to prevent re-loading. Spent brass larger than .50 caliber is NOT QRP eligible and MUST be turned over to DLA. Intact brass (i.e., not deformed) can be sold only through DLA.

\subsection{Option 1: Brass sales through DLA}

Fort Huachuca's current practice to send installation brass that is recyclable to DLA. The benefits of this process are that DLA coordinates all the logistics, paperwork, and safety certifications. The drawbacks of using DLA sales are that the brass prices achieved through DLA are usually lower than open market prices, and reimbursement from DLA to the QRP can take several months. In fact, in a 2017 memo, DLA put FY2017 reimbursements on hold, pending a review of their accounting systems. ${ }^{22}$

\subsection{Option 2: Direct sales by QRP}

At U.S. Army training ranges, the spent brass casings must be retrieved from the field and turned in to the ASP. As mentioned above, all brass casings .50 caliber and below that are recycled through the QRP must be deformed before they are sold on the open market. This deformation can be done with a type of machine called an "expanded shell ordinance casings deformer" (EOCD).

The standard QRP turn-in Form DD 1348 is used to keep track of all the materials that go through the QRP. In the case of brass, the form will track the brass from the hand-off at the ammunition supply point (ASP) and back to the QRP. One person associated with QRP management should be

\footnotetext{
22 Defense Logistics Agency, Memorandum for Qualified Recycling Program Managers (Battle Creek, MI: DLA Disposition Services, 12 July 2017).
} 
responsible for overseeing the brass that goes through the QRP and should safety-certify the brass listed on Form DD 1348.

A typical process for handling brass on installations is as follows:

1. Soldiers pick up munition casings from the field (ranges) and bring them to the ASP.

2. After the munitions are sorted, the ASP representative weighs each category.

3. Next, a Quality Ammunition and Surveillance Assurance Specialist (QASAS) verifies the amounts and types and that prescribed handling procedures are followed.

4. Then the DD 1348 is filled out for the brass quantities, and the form is signed by someone from the ASP and someone from QRP management.

5. Brass is now ready for demilitarization.

6. Once an adequate quantity of brass has accumulated, QRP management can contact the vendors with whom they have sales agreements.

7. QRP management will then fill out a brass pick-up receipt that must accompany every vehicle picking up the brass.

8. Trucks weigh in empty (except for pallets) and weigh out again when full; specific information must be recorded by the QRP for every truckload of brass (e.g., \# of pallets, tractor \#, trailer \#, and license plate \#).

9. Both QRP management and the truck driver receive copies of brass pick-up receipts.

\subsection{QRP Feasibility}

While brass is a relatively valuable commodity, the cost to prepare brass for market is also high. For a QRP program to directly sell brass, the value of the brass must be weighed against the one-time cost of safety certification equipment and the recurring O\&M cost (labor and utilities) that must be paid by the QRP. Therefore, for direct sales of brass, the volume generated must be great enough to offset the costs. Unfortunately, a return on investment (ROI) analysis shows that direct sales of brass through the QRP is not economical for Fort Huachuca. Table 5 gives a summary of the calculations that went into the ROI analysis. More detail is shown in this report's Appendix, including photos and prices of the equipment required (Figure A1 and Figure A2). 
Table 5. Projected ROI for brass direct sales (ERDC-CERL).

\begin{tabular}{|c|c|c|}
\hline Cost / Benefits & \multicolumn{2}{|c|}{ Brass } \\
\hline ROI payback period & (never) & \\
\hline Gross annual income & $\$ 21,000$ & \\
\hline Annual cost & $\$ 27,000$ & \\
\hline NET INCOME (avoided costs \& savings) & $\$(6,000)$ & \\
\hline QUANTITY OF RECYCLING & 6 & tons/yr. \\
\hline Capital purchase, safety certification unit & $\$ 146,000$ & \\
\hline Labor (to install) & 2,400 & 40 hours \\
\hline Connection to utilities at site & 10,000 & \\
\hline Staff time for coordination, contracting, etc. & 10,000 & 3 weeks \\
\hline Training and travel ( 4 people) & 34,000 & 2 weeks TDY* \\
\hline Purchase brass deformer & 73,000 & \\
\hline ONE-TIME COSTS & $\$ 275,400$ & \\
\hline DPW Staff labor (2 weeks) & $\$ 6,000$ & 2 weeks \\
\hline O\&M Labor, Gov't (2 people) & $\$ 10,000$ & 2 weeks \\
\hline Service calls & $\mathrm{N} / \mathrm{A}$ & \\
\hline Contractor labor & $\mathrm{N} / \mathrm{A}$ & \\
\hline Periodic training (2 people) & $\$ 5,000$ & 1 week \\
\hline Parts & $\$ 5,000$ & \\
\hline Electricity for deformer & $\$ 164$ & \\
\hline Propane for Safety Certifier & $\$ 1,320$ & \\
\hline Annual Costs & $\$ 27,484$ & \\
\hline
\end{tabular}

TDY = temporary duty 


\section{Optimizing Collection Strategy}

This section presents possible strategies for efficient collection of recyclables at Fort Huachuca and increased profits for QRP management. It does this by evaluating the following three potential scenarios:

Scenario \#1: Collection from all buildings. This is accomplished by examining the whole installation block by block to determine optimum placement and number of exterior collection containers. There are two sub-scenarios: Scenario 1A for collection via contractor and Scenario \#1B for collection via DPW staff.

Scenario \#2: Collection from specific building types. This scenario shows tables that categorize installation buildings by type (i.e., all office buildings, all instructional buildings, all industrial buildings, etc.) to determine which building types generate the most recyclables.

Scenario \#3: Collection from specific buildings. This scenario identifies the individual buildings with the highest projected recyclable generation rates.

For all three scenarios, quantities and example costs for interior and exterior containers are provided. Then, an ROI is calculated for each.

Because Fort Huachuca does not have a recycling program currently, it makes sense to begin the program with the recyclables that either have the highest market value or that federal regulation requires to be recycled. These recommended recyclables are as follows: office paper (mandatory under certain circumstances, see Section 2.2), cardboard (mandatory under certain circumstances, see Section 2.2), aluminum cans, steel cans, and \#1 and \#2 plastics.

\subsection{Scenario \#1: Collection from all buildings}

If the intention is to collect recyclables post-wide, this scenario strategizes the most central building pick up locations (with a minimum of collection sites). The most efficient way to determine number of collection points is to identify the buildings that must be individually serviced and then map the groups of buildings that can share containers. Certainly, the goal is to provide complete recycling pick-up coverage while minimizing the number 
of collection locations a recycling truck has to visit. Table 6 considers the Fort Huachuca map, block by block, and suggests locations for recycling collection. Note here that Section 7.1 applies to both Scenarios \#1A and \#1B. See Appendix A for ROI calculations for these two sub-scenarios.

While Scenario \#1 assumes installation-wide recycling, it attempts to minimize the number of pickups by identifying groups of buildings that can share exterior recycling bins. Thus, it is important here to consider a building' generation rates for each recyclable. Buildings that generate low numbers of recyclables will be aggregated with buildings that generate high numbers of recyclables. In this scenario, exterior recycle bins will be placed closest to the building with the highest numbers of recyclables. For yet greater efficiency this scenario assumes a minimum of three external containers: one each for white paper and cardboard, and one for the collection of aluminum, plastic, and steel containers, which will either be commingled in one container or source separated in one compartmentalized container with three slots.

Based on the Scenario \#1 analyses, the recommended minimum number of building and building group locations is 84 . See Table 6 for suggested exterior container locations.

The quantity and placement of interior recycling bins are also considered for Scenario \#1. Table 7 gives the overall cost of both interior and exterior containers. See Appendix A and Table A1 for a more detailed explanation and listing of the number of interior and exterior bins for this scenario.

When considering this scenario, it is not only important to determine the quantities of recyclables generated at each site (as discussed above), but it is also necessary to take into account the time an outdoor container will take to fill. This time will determine the container size required for a specific building location and the frequency of container pick up. Table 7 lists the costs and the types of containers Fort Huachuca can use for recycling collection. The costs are calculated according to the number of interior and exterior containers recommended here for each building, and are based on building type and size. Figure 1, Figure 2, and Figure 3 show the types of containers and prices that were used for Table 7 calculations. Table 8 projects Scenario \#1 total values for recyclables across the installation. For detail by building of interior and exterior container numbers and their costs, see discussion of Scenario \#1 in Appendix A. 
Table 6. Suggested recycling container exterior locations (ERDC-CERL).

\begin{tabular}{|c|c|c|c|}
\hline Block Number & $\begin{array}{l}\text { Container Locations } \\
\text { (closest building \#) }\end{array}$ & Block Number & $\begin{array}{l}\text { Container Locations } \\
\text { (closest building \#) }\end{array}$ \\
\hline 154 & 79 & 573 & 05 \\
\hline 211 & 12 & 574 & 28 \\
\hline 222 & 14 & 616 & 10 \\
\hline 223 & 26 & 617 & 30 \\
\hline 224 & 10 & 618 & 01,09 \\
\hline 225 & 26 & 627 & $18,22,50,02,04$ \\
\hline 300 & 10 & 638 & 45 \\
\hline 301 & 15 & 639 & 02,20 \\
\hline 310 & 44 & 676 & 01 \\
\hline 311 & 22 & 705 & 25 \\
\hline 413 & 30 & 728 & 05 \\
\hline 414 & $08,15,20$ & 758 & 01 \\
\hline 450 & 05,01 & 759 & 02 \\
\hline 451 & 03 & 800 & 11 \\
\hline 468 & 02 & 801 & 22 \\
\hline 471 & 21 & 803 & 05 \\
\hline 481 & 01 & 804 & 05 \\
\hline 482 & 28 & 805 & $05,03,04$ \\
\hline 490 & 13,55 & 807 & 06 \\
\hline 500 & 10 & 813 & 05 \\
\hline 510 & 05,01 & 814 & 05 \\
\hline 511 & 02 & 815 & 02 \\
\hline 512 & 01 & 820 & 12 \\
\hline 513 & 01 & 825 & 02 \\
\hline 514 & 51 & 828 & 12 \\
\hline 520 & $P X, 56,60,65$ & 844 & 02 \\
\hline 521 & $01,10,36,07,04$ & 852 & 02 \\
\hline 522 & 04 & 853 & 02 \\
\hline 523 & 13 & 863 & 02 \\
\hline 533 & 01,20 & 911 & 12 \\
\hline
\end{tabular}




\begin{tabular}{|c|l|c|l|}
\hline Block Number & $\begin{array}{l}\text { Container Locations } \\
\text { (closest building \#) }\end{array}$ & Block Number & $\begin{array}{l}\text { Container Locations } \\
\text { (closest building \#) }\end{array}$ \\
\hline 553 & 50 & 912 & 51 \\
\hline 563 & 01 & \multicolumn{2}{|l}{} \\
\cline { 1 - 2 } & &
\end{tabular}

Table 7. Cost of recycling containers according to the recommended number of interior and exterior containers based on building type and size (ERDC-CERL, 2017).

\begin{tabular}{|l|r|r|r|}
\hline Container & Quantity & Cost Each & $\begin{array}{l}\text { Total Cost per } \\
\text { Type Container }\end{array}$ \\
\hline $\begin{array}{l}64 \text { gallon toter for } \\
\text { office paper, exterior }\end{array}$ & 380 & $\$ 129$ & $\$ 49,067$ \\
\hline $\begin{array}{l}64 \text { gallon toter for } \\
\text { plastic and metal } \\
\text { containers, } \\
\text { commingled, exterior }\end{array}$ & 380 & $\$ 129$ & $\$ 49,067$ \\
\hline $\begin{array}{l}\text { 4-yard dumpsters for } \\
\text { cardboard, exterior }\end{array}$ & 111 & $\$ 900$ & $\$ 99,900$ \\
\hline $\begin{array}{l}\text { 23-gallon office } \\
\text { paper interior }\end{array}$ & 1949 & $\$ 14.85$ & $\$ 28,940$ \\
\hline $\begin{array}{l}\text { 23-gallon, mixed } \\
\text { containers, interior }\end{array}$ & 1949 & $\$ 14.85$ & $\$ 28,940$ \\
\hline \multicolumn{3}{|c|}{ TOTAL All Container Costs } & $\$ 255,913$ \\
\hline
\end{tabular}

Figure 1. Example of recycling container that could be used at Fort Huachuca (priced at GSA Advantage). ${ }^{23}$

\begin{tabular}{|c|c|c|}
\hline & \multicolumn{2}{|c|}{ 64GAL 2WHL RECYC CART } \\
\hline 19 & $\begin{array}{l}\text { Mfr Part No.: } \\
\text { Contractor Part No.: } \\
\text { Manufacturer: } \\
\text { Contract No.: } \\
\text { MAS Schedule/SIN: } \\
\text { Warranty: } \\
\text { Made In: } \\
\text { Weight: }\end{array}$ & $\begin{array}{l}25564-05 B L U \\
138993 \\
\text { TOTER INCORPORATED } \\
\text { GS-21F-0104W (ends: Feb 29, 2020) } \\
51 \text { V } 105002 \\
30 \text { DA } \\
\text { UNITED STATES OF AMERICA } \\
28.000 \text { LB }\end{array}$ \\
\hline & \multicolumn{2}{|c|}{$\begin{array}{l}\text { DISSST } \\
\text { PURCH Disaster Purchasing items }\end{array}$} \\
\hline Enlarge/More Views >> & \multicolumn{2}{|l|}{ Desc } \\
\hline $\begin{array}{l}\$ 120.29 \text { EA } \\
\text { sold and shipped by } \\
\text { HARDWARE INC } \\
\text { visit contractor's website } 19\end{array}$ & \multicolumn{2}{|c|}{$\begin{array}{l}\text { TOTER INCORPORATED, 64GAL } 2 \text { WHL Recyc Cart, } 64 \text { Gallon, } 2 \text { Wheel, Blue Recycle Cart, With Attached Lid, } \\
\text { Manufactured Using Medium Density Polyethylene } \& \text { Up To } 50 \% \text { Recycled Content, Fully Recyclable, Wheel } \\
\text { Make It Easier To Tilt \& Rolll. *Please contact us toll free at 1-877-944-4610 or by e-mail } \\
\text { mro@hardwareincnola.com for additional product information. }\end{array}$} \\
\hline
\end{tabular}

${ }^{23}$ https://www.gsaadvantage.gov/advantage/catalog/product_detail.do?gsin=11000030198650 
Figure 2. Example exterior container for cardboard (manufactured by Global Industrial).

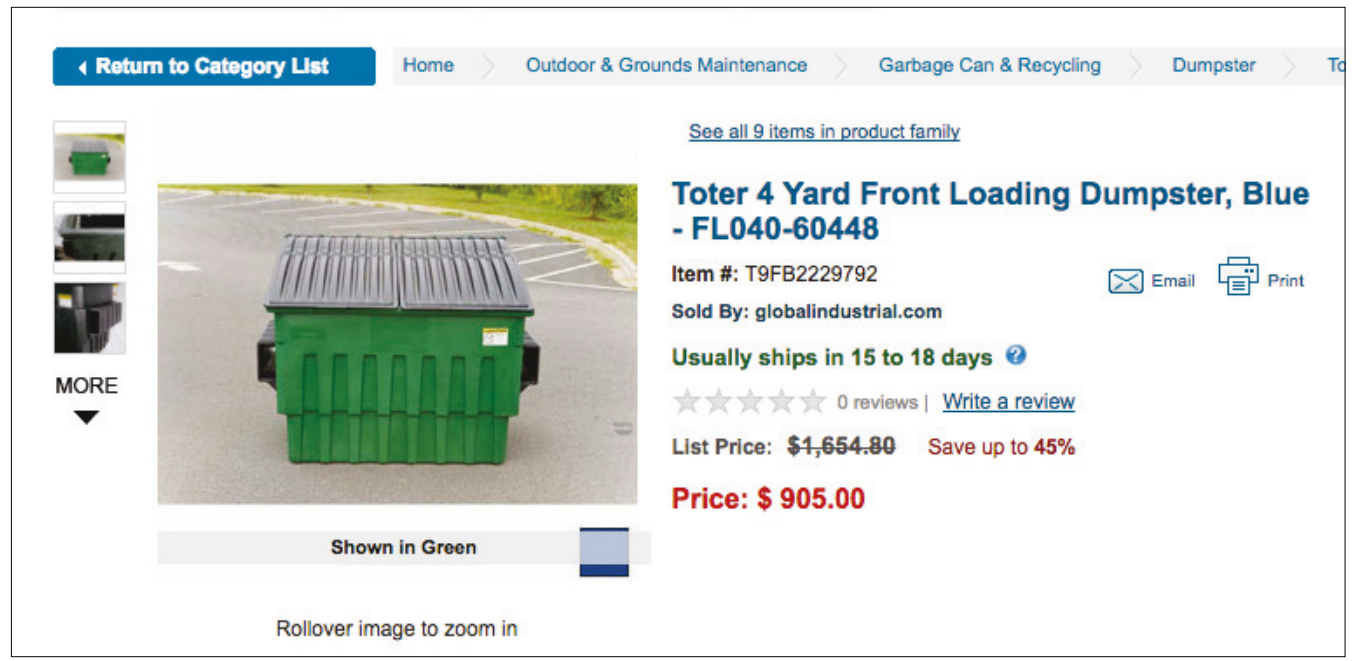

Figure 3. Example interior recycling bin (manufactured by Grainger).

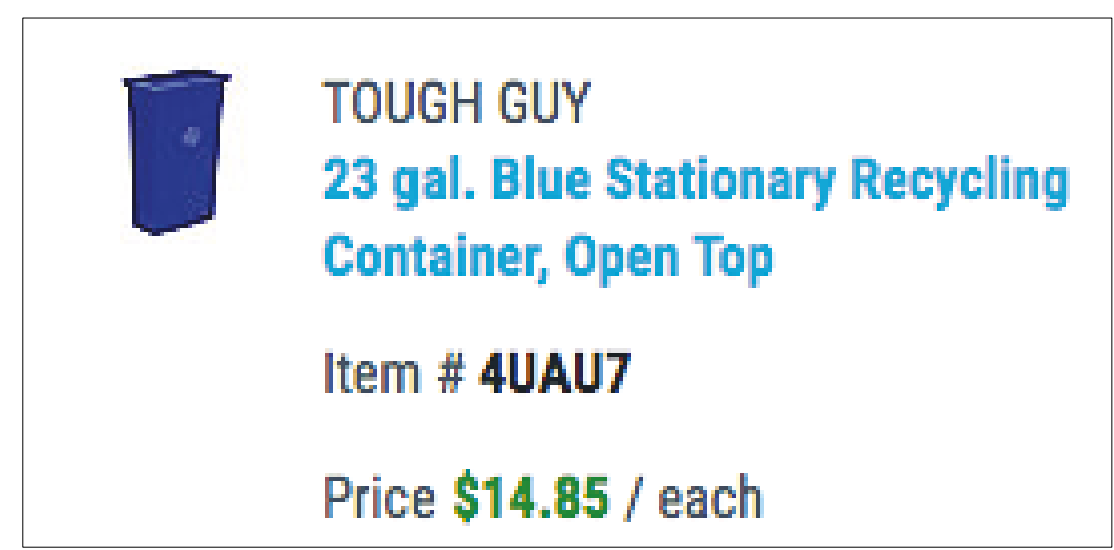

Table 8. Total value of recyclables (ERDC-CERL).

\begin{tabular}{|l|r|r|r|}
\hline Material Type & $\begin{array}{l}\text { Market } \\
\text { Value } \\
\text { (per ton) }\end{array}$ & $\begin{array}{l}\text { Installation - } \\
\text { Wide Quantity } \\
\text { (ton/year) }\end{array}$ & Total Value \\
\hline $\begin{array}{l}\text { Plastic \#1 } \\
\text { (baled) }\end{array}$ & $\$ 160$ & 219 & $\$ 35,019$ \\
\hline $\begin{array}{l}\text { Plastic \#2 } \\
\text { (baled, } \\
\text { pigmented) }\end{array}$ & $\$ 260$ & 58 & $\$ 15,145$ \\
\hline $\begin{array}{l}\text { Aluminum } \\
\text { (baled) }\end{array}$ & $\$ 700$ & 79 & $\$ 55,323$ \\
\hline $\begin{array}{l}\text { Cardboard } \\
\text { (baled) }\end{array}$ & $\$ 125$ & 454 & $\$ 56,701$ \\
\hline Mixed paper & $\$ 100$ & 50 & $\$ 4,968$ \\
\hline Steel & $\$ 160$ & 114 & $\$ 18,193$ \\
\hline
\end{tabular}




\begin{tabular}{|c|c|c|c|}
\hline Material Type & $\begin{array}{l}\text { Market } \\
\text { Value } \\
\text { (per ton) }\end{array}$ & $\begin{array}{l}\text { Installation - } \\
\text { Wide Quantity } \\
\text { (ton/year) }\end{array}$ & Total Value \\
\hline $\begin{array}{l}\text { White paper } \\
\text { (baled) }\end{array}$ & $\$ 120$ & 491 & $\$ 58,925$ \\
\hline TOTAL & & 1,464 & $\$ 244,273$ \\
\hline
\end{tabular}

\subsection{Scenario \#2: Recyclable collection by building type}

To establish generation of recyclables by building type, two tables were created, with data drawn from the ERDC-CERL Fort Huachuca waste characterization study. Table 9 shows the expected annual generation of recyclables by each building for all the buildings at Fort Huachuca. The rows list building types, and the columns show the predicted annual weight of a specific recyclable material. Table 10 shows the value of the recyclables generated per year by building type. The purpose of these two tables is to identify the building types that produce the highest weight of recyclables as well as those recyclables with the greatest value. The tables show that general information buildings (GIB) and dining facilities (DFAC), training barracks, PXs, and tactical equipment maintenance facility (TEMFs) produce the most recyclables in terms of both total weight and value. Table A4 in the Appendix gives a complete list of buildings and containers used for calculations used in this scenario.

Table 9. Annual recyclable generation amounts at Fort Huachuca for all buildings by building type (ERDC-CERL).

\begin{tabular}{|c|c|c|c|c|c|c|c|c|}
\hline \multirow[b]{2}{*}{ Building Type } & \multicolumn{7}{|c|}{ Weight (tons) by Recyclable Type per Building } & \multirow{2}{*}{$\begin{array}{l}\text { Total } \\
\text { Recycl. } \\
\text { per Bldg } \\
\text { (tons) }\end{array}$} \\
\hline & \#1 & \#2 & Aluminum & $\begin{array}{l}\text { Corrugated } \\
\text { Cardboard }\end{array}$ & $\begin{array}{l}\text { Mixed } \\
\text { Paper }\end{array}$ & $\begin{array}{l}\text { Steel } \\
\text { Cans (Fe) }\end{array}$ & $\begin{array}{l}\text { White } \\
\text { Paper }\end{array}$ & \\
\hline GIB & 151.96 & 28.6 & 42.9 & 113.71 & 17.85 & 49.35 & 398.49 & 802.86 \\
\hline DFAC & 0.98 & 5.23 & 6.15 & 154.22 & 0.12 & 12 & 2.15 & 180.85 \\
\hline PX & 9.02 & 9.80 & 2.25 & 51.47 & 0.75 & 0.75 & 1.80 & 75.84 \\
\hline TEMF & 12.53 & 2.00 & 2.34 & 36.31 & 0.16 & 4.00 & 12.61 & 69.95 \\
\hline $\begin{array}{l}\text { Training } \\
\text { Barracks }\end{array}$ & 14.85 & 5.32 & 10.08 & 27.22 & 3.72 & 0.00 & 4.24 & 65.43 \\
\hline Infosys & 6.71 & 1.52 & 3.03 & 8.01 & 15.15 & 1.3 & 14.07 & 49.79 \\
\hline GPW & 1.3 & 0.49 & 0.49 & 21.77 & 7 & 7.05 & 11.24 & 49.34 \\
\hline CDC & 1.12 & 0.87 & 0.38 & 15.53 & 0.13 & 12.2 & 0.62 & 30.85 \\
\hline Religious & 12.53 & 0.30 & 7.45 & 0.40 & 1.19 & 0.00 & 0.30 & 22.17 \\
\hline
\end{tabular}




\begin{tabular}{|c|c|c|c|c|c|c|c|c|}
\hline \multirow[b]{2}{*}{ Building Type } & \multicolumn{7}{|c|}{ Weight (tons) by Recyclable Type per Building } & \multirow{2}{*}{$\begin{array}{l}\text { Total } \\
\text { Recycl. } \\
\text { per Bldg } \\
\text { (tons) }\end{array}$} \\
\hline & \#1 & \#2 & Aluminum & $\begin{array}{l}\text { Corrugated } \\
\text { Cardboard }\end{array}$ & $\begin{array}{l}\text { Mixed } \\
\text { Paper }\end{array}$ & $\begin{array}{l}\text { Steel } \\
\text { Cans (Fe) }\end{array}$ & $\begin{array}{l}\text { White } \\
\text { Paper }\end{array}$ & \\
\hline UEPH & 2.75 & 2.97 & 1.27 & 9.03 & 0.21 & 2.33 & 0.21 & 18.77 \\
\hline $\begin{array}{l}\text { Outpatient } \\
\text { Health } \\
\text { Center }(\mathrm{OHC})\end{array}$ & 0 & 0 & 0 & 0 & 0 & 0 & 13.44 & 13.44 \\
\hline $\begin{array}{l}\text { Retail } \\
\text { Supermarket }\end{array}$ & 0.29 & 0.00 & 0.87 & 3.13 & 0.67 & 0.00 & 2.97 & 7.93 \\
\hline Office - small & 0.51 & 0.06 & 0.12 & 0 & 0.34 & 5.88 & 0.06 & 6.97 \\
\hline $\mathrm{COF}$ & 0.99 & 0.4 & 0.59 & 3.43 & 0.2 & 0 & 0.99 & 6.6 \\
\hline $\begin{array}{l}\text { Healthcare - } \\
\text { Hospital }\end{array}$ & 0 & 0 & 0 & 5.66 & 0 & 0 & 0 & 5.66 \\
\hline PFF & 0.65 & 0.08 & 0.08 & 0.00 & 0.89 & 0.08 & 0.08 & 1.86 \\
\hline
\end{tabular}

GPW = general purpose warehouse; $\mathrm{CDC}=$ Child Development Center; UEPH = unaccompanied personnel housing; $\mathrm{COF}=$ Company Operations facility; and PFF = physical fitness facility.

Table 10. Recyclable values generated per year by building type (ERDC-CERL).

\begin{tabular}{|c|c|c|c|c|c|c|c|c|}
\hline \multirow[b]{2}{*}{ Building Type } & \multicolumn{7}{|c|}{ Value of Recyclable Type per Building Type } & \multirow{2}{*}{$\begin{array}{c}\text { Total } \\
\text { Annual } \\
\text { Value, } \\
\text { (per bldg. } \\
\text { type ) }\end{array}$} \\
\hline & $\begin{array}{l}\text { \#1 } \\
\text { Plastic }\end{array}$ & $\begin{array}{l}\text { \#2 } \\
\text { Plastic }\end{array}$ & $\begin{array}{l}\text { Aluminum } \\
\text { Cans }\end{array}$ & $\begin{array}{c}\text { Corr. } \\
\text { Cardboard }\end{array}$ & $\begin{array}{l}\text { Mixed } \\
\text { Paper }\end{array}$ & $\begin{array}{l}\text { Steel } \\
\text { Cans }\end{array}$ & $\begin{array}{l}\text { White } \\
\text { Paper }\end{array}$ & \\
\hline GIB & $\begin{array}{r}\$ 24,31 \\
4\end{array}$ & $\$ 7,436$ & $\$ 30,030$ & $\$ 14,214$ & $\$ 1,785$ & $\$ 7,896$ & $\$ 47,819$ & $\$ 133,493$ \\
\hline DFAC & $\$ 157$ & $\$ 1,360$ & $\$ 4,305$ & $\$ 19,278$ & $\$ 12$ & $\$ 1,920$ & $\$ 258$ & $\$ 27,289$ \\
\hline $\begin{array}{l}\text { Training } \\
\text { Barracks }\end{array}$ & $\$ 2,376$ & $\$ 1,383$ & $\$ 7,059$ & $\$ 3,403$ & $\$ 372$ & $\$ 0$ & $\$ 509$ & $\$ 15,102$ \\
\hline PX & $\$ 1,443$ & $\$ 2,548$ & $\$ 1,578$ & $\$ 6,434$ & $\$ 75$ & $\$ 119$ & $\$ 216$ & $\$ 12,413$ \\
\hline TEMF & $\$ 2,005$ & $\$ 520$ & $\$ 1,635$ & $\$ 4,539$ & $\$ 16$ & $\$ 640$ & $\$ 1,513$ & $\$ 10,869$ \\
\hline Infosys & $\$ 1,074$ & $\$ 395$ & $\$ 2,121$ & $\$ 1,001$ & $\$ 1,515$ & $\$ 208$ & $\$ 1,688$ & $\$ 8,002$ \\
\hline Religious & $\$ 2,004$ & $\$ 78$ & $\$ 5,216$ & $\$ 50$ & $\$ 119$ & $\$ 0$ & $\$ 36$ & $\$ 7,504$ \\
\hline GPW & $\$ 208$ & $\$ 127$ & $\$ 343$ & $\$ 2,721$ & $\$ 700$ & $\$ 1,128$ & $\$ 1,349$ & $\$ 6,576$ \\
\hline CDC & $\$ 179$ & $\$ 226$ & $\$ 266$ & $\$ 1,941$ & $\$ 13$ & $\$ 1,952$ & $\$ 74$ & $\$ 4,652$ \\
\hline UEPH & $\$ 440$ & $\$ 771$ & $\$ 886$ & $\$ 1,129$ & $\$ 21$ & $\$ 372$ & $\$ 25$ & $\$ 3,645$ \\
\hline $\begin{array}{l}\text { Outpatient } \\
\text { Health Center } \\
(\mathrm{OHC})\end{array}$ & $\$ 0$ & $\$ 0$ & $\$ 0$ & $\$ 0$ & $\$ 0$ & $\$ 0$ & $\$ 1,613$ & $\$ 1,613$ \\
\hline $\begin{array}{l}\text { Retail } \\
\text { supermarket }\end{array}$ & $\$ 46$ & $\$ 0$ & $\$ 608$ & $\$ 391$ & $\$ 67$ & $\$ 0$ & $\$ 357$ & $\$ 1,470$ \\
\hline
\end{tabular}




\begin{tabular}{|c|c|c|c|c|c|c|c|c|}
\hline \multirow[b]{2}{*}{ Building Type } & \multicolumn{7}{|c|}{ Value of Recyclable Type per Building Type } & \multirow{2}{*}{$\begin{array}{c}\text { Total } \\
\text { Annual } \\
\text { Value, } \\
\text { (per bldg. } \\
\text { type ) }\end{array}$} \\
\hline & $\begin{array}{c}\text { \#1 } \\
\text { Plastic }\end{array}$ & $\begin{array}{c}\text { \#2 } \\
\text { Plastic }\end{array}$ & $\begin{array}{l}\text { Aluminum } \\
\text { Cans }\end{array}$ & $\begin{array}{c}\text { Corr. } \\
\text { Cardboard }\end{array}$ & $\begin{array}{l}\text { Mixed } \\
\text { Paper }\end{array}$ & $\begin{array}{l}\text { Steel } \\
\text { Cans }\end{array}$ & $\begin{array}{l}\text { White } \\
\text { Paper }\end{array}$ & \\
\hline COF & $\$ 158$ & $\$ 104$ & $\$ 413$ & $\$ 429$ & $\$ 20$ & $\$ 0$ & $\$ 119$ & $\$ 1,243$ \\
\hline Office - small & $\$ 82$ & $\$ 16$ & $\$ 84$ & $\$ 0$ & $\$ 34$ & $\$ 941$ & $\$ 7$ & $\$ 1,163$ \\
\hline $\begin{array}{l}\text { Healthcare - } \\
\text { Hospital }\end{array}$ & $\$ 0$ & $\$ 0$ & $\$ 0$ & $\$ 708$ & $\$ 0$ & $\$ 0$ & $\$ 0$ & $\$ 708$ \\
\hline PFF & $\$ 103$ & $\$ 20$ & $\$ 55$ & $\$ 0$ & $\$ 89$ & $\$ 13$ & $\$ 10$ & $\$ 290$ \\
\hline
\end{tabular}

\subsection{Scenario \#3: Collection from specific buildings}

Scenario \# 3 drills deeper into projected recyclable generation at the individual building level to target specific buildings for recycling collection, in order to get the most value for the collection effort. In short, this scenario identifies both the buildings from which recycling should be collected as well as the buildings from which recycling should NOT be collected. The downside for this approach is that the recycling message might seem inconsistent to soldiers and employees (i.e., recycling in some buildings and not in others).

Table 11 identifies the buildings at Fort Huachuca that are projected to produce the greatest quantities of each recommended recyclable material. ${ }^{24}$ The blue cells highlight recyclable generation rates in the top ten across the installation. For example, building \#11640 is shown to be one of the top 10 for generating \#1 plastic and white paper. Looking down each column, notice there are 10 highlighted cells for each recyclable material, and these cells correspond to the top 10 quantities of each material.

Not only do these 25 buildings generate proportionally large amounts of recyclables, but also they account for close to half the revenue projected from recyclables for the entire installation (refer to Table 4 for total projected revenues).

\footnotetext{
24 Please recall that these figures are merely projections based on a one-week waste characterization study.
} 
When planning pick-up schedules, it is most cost effective to make one trip to a building to collect all the recyclables rather than making several trips to pick up source-separated recyclables. Therefore, when calculating overall value of recyclables collected, the values for all the materials generated at a specific building were included. See Table 12 for potential market values for all the buildings and recyclables listed in Table 11. For a more detailed building list, refer to Table A6 in Appendix A, which shows the different sections and functions of large buildings and the number of containers to assign to each.

Table 11. Top 25 buildings for project recyclable generation (ton/year) (ERDC-CERL).

\begin{tabular}{|c|c|c|c|c|c|c|c|c|}
\hline Bldg. \# & Organization & $\begin{array}{c}\text { \#1 } \\
\text { plastic }\end{array}$ & $\begin{array}{c}\text { \#2 } \\
\text { plastic }\end{array}$ & $\mathrm{Al}$ & $\begin{array}{c}\text { Old } \\
\text { Corrugated } \\
\text { Cardboard } \\
\text { (OCC) }\end{array}$ & $\begin{array}{l}\text { Mixed } \\
\text { paper }\end{array}$ & $\begin{array}{l}\text { Steel } \\
\text { Can }\end{array}$ & $\begin{array}{l}\text { White } \\
\text { Paper }\end{array}$ \\
\hline 11640 & 2-13 AVN REGT & 5.40 & 1.02 & 1.52 & 4.04 & 0.63 & 1.75 & 14.16 \\
\hline 45001 & $\begin{array}{l}\text { RAYMOND W. BLISS } \\
\text { CLINIC }\end{array}$ & 0.00 & 0.00 & 0.00 & 5.66 & 0.00 & 0.00 & 26.42 \\
\hline 48101 & CDC, FMWR & 0.38 & 0.30 & 0.13 & 5.33 & 0.04 & 4.19 & 0.21 \\
\hline 49055 & CDC, FMWR & 0.29 & 0.23 & 0.10 & 4.04 & 0.03 & 3.17 & 0.16 \\
\hline 51005 & HHC USAICoE & 4.24 & 1.30 & 2.35 & 6.52 & 0.90 & 0.76 & 4.90 \\
\hline 52030 & MAIN EXCHANGE & 4.26 & 4.62 & 1.06 & 24.29 & 0.36 & 0.36 & 0.85 \\
\hline 52056 & CYS SERVICES, FMWR & 0.45 & 0.35 & 0.15 & 6.17 & 0.05 & 4.84 & 0.25 \\
\hline 52107 & BDE HHC THEAT TAC SIG & 0.14 & 0.76 & 0.89 & 22.30 & 0.02 & 1.74 & 0.31 \\
\hline 53301 & $\begin{array}{l}\text { TECHNOLOGY } \\
\text { INTERGRATION CENTER }\end{array}$ & 0.49 & 0.11 & 0.23 & 0.59 & 1.11 & 0.10 & 1.03 \\
\hline 53302 & $\begin{array}{l}\text { TECHNOLOGY } \\
\text { INTERGRATION CENTER }\end{array}$ & 0.49 & 0.11 & 0.23 & 0.59 & 1.11 & 0.10 & 1.03 \\
\hline 55350 & $E P G$ & 0.53 & 0.12 & 0.24 & 0.64 & 1.20 & 0.10 & 1.12 \\
\hline 57305 & $\begin{array}{l}\text { DISA JOINT INTEROP TEST } \\
\text { CMD SPT }\end{array}$ & 1.20 & 0.27 & 0.54 & 1.43 & 2.71 & 0.23 & 2.51 \\
\hline 57428 & $\begin{array}{l}\text { DISA JOINT INTEROP TEST } \\
\text { CMD SPT }\end{array}$ & 0.74 & 0.17 & 0.34 & 0.89 & 1.68 & 0.14 & 1.56 \\
\hline 61801 & ACT USA SIGNAL NETWOR & 6.23 & 1.36 & 2.16 & 6.86 & 3.25 & 12.55 & 11.57 \\
\hline 61809 & CO B $305 \mathrm{Ml} B N$ & 20.60 & 3.88 & 5.82 & 15.41 & 2.42 & 6.69 & 54.03 \\
\hline 61820 & $305 \mathrm{Ml} \mathrm{BN}$ & 7.37 & 1.39 & 2.08 & 5.51 & 0.86 & 2.39 & 19.32 \\
\hline 63845 & CTR USA INT CEN \& FT & 10.21 & 1.92 & 2.89 & 7.65 & 1.25 & 3.31 & 26.77 \\
\hline 63902 & CO A $305 \mathrm{Ml} \mathrm{BN}$ & 20.32 & 3.82 & 5.73 & 15.13 & 2.44 & 7.76 & 53.03 \\
\hline 70525 & $\begin{array}{l}\text { THUNDER MOUNTAIN } \\
\text { ACTIVITY CENTER }\end{array}$ & 0.27 & 1.41 & 1.66 & 41.58 & 0.03 & 3.24 & 0.58 \\
\hline 80122 & CO D $306 \mathrm{Ml} \mathrm{BN}$ & 9.42 & 1.77 & 2.66 & 7.05 & 1.10 & 3.06 & 24.71 \\
\hline 80503 & REAL PROPERTY, DPW & 0.13 & 0.68 & 0.80 & 19.99 & 0.02 & 1.56 & 0.28 \\
\hline
\end{tabular}




\begin{tabular}{|l|l|r|r|r|r|r|r|r|}
\hline Bldg. \# & \multicolumn{1}{|c|}{ Organization } & $\begin{array}{c}\text { \#1 } \\
\text { plastic }\end{array}$ & $\begin{array}{c}\text { \#2 } \\
\text { plastic }\end{array}$ & \multicolumn{1}{|c|}{ Al } & $\begin{array}{c}\text { Old } \\
\text { Corrugated } \\
\text { Cardboard } \\
\text { (OCC) }\end{array}$ & $\begin{array}{l}\text { Mixed } \\
\text { paper }\end{array}$ & $\begin{array}{c}\text { Steel } \\
\text { Can }\end{array}$ & $\begin{array}{c}\text { White } \\
\text { Paper }\end{array}$ \\
\hline 80504 & REAL PROPERTY, DPW & 0.13 & 0.68 & 0.80 & 20.16 & 0.02 & 1.57 & 0.28 \\
\hline 80505 & CO A 304 MI BN & 12.62 & 2.37 & 3.56 & 9.44 & 1.48 & 4.10 & 33.08 \\
\hline 85202 & AlT Complex & 0.29 & 1.55 & 1.83 & 45.74 & 0.04 & 3.56 & 0.64 \\
\hline 91122 & 2-13 AVN REGT & 5.29 & 1.00 & 1.49 & 3.96 & 0.62 & 1.72 & 13.87 \\
\hline
\end{tabular}

Table 12. Projected market value of recyclables at the top-producing buildings (ERDC-CERL).

\begin{tabular}{|l|r|r|}
\hline \multicolumn{1}{|c|}{ Material Type } & $\begin{array}{c}\text { Market } \\
\text { Value } \\
(\$ / \text { Ton) }\end{array}$ & \multicolumn{1}{c|}{$\begin{array}{c}\text { Total Mkt. } \\
\text { Value }\end{array}$} \\
\hline Plastic \#1 (baled) & $\$ 160$ & $\$ 17,837$ \\
\hline $\begin{array}{l}\text { Plastic \#2 (baled, } \\
\text { pigmented) }\end{array}$ & $\$ 260$ & $\$ 8,108$ \\
\hline Aluminum (baled) & $\$ 700$ & $\$ 27,478$ \\
\hline $\begin{array}{l}\text { Cardboard } \\
\text { (baled) }\end{array}$ & $\$ 125$ & $\$ 35,118$ \\
\hline Mixed paper & $\$ 100$ & $\$ 2,339$ \\
\hline Steel & $\$ 160$ & $\$ 11,036$ \\
\hline $\begin{array}{l}\text { White paper } \\
\text { (baled) }\end{array}$ & $\$ 35,119$ \\
\hline TOTAL & $\$ 137,035$ \\
\hline
\end{tabular}




\section{Summary: Costs and Benefits of Three Scenarios for a QRP}

\subsection{Economic evaluation, with scenarios}

Table 13 provides an analysis of the costs and benefits for each recycling scenario listed below:

- Scenario \#1A: Collection from all buildings via contractor labor.

- Scenario \#1B: Collection from all buildings via DPW staff.

- Scenario \#2: Collection by building type.

- Scenario \#3: Collection from specific buildings.

Table 13 highlights seven cost and benefit concerns: (1) net income, (2) gross annual savings per building, (3) quantity of recycling, (4) income, (5) one-time costs, (6) annual costs, and (7) avoidance costs. Taken together, these cost-benefit concerns paint a comprehensive picture of the main operational costs and benefits to consider when implementing an installation recycling program.

While there are benefits to all the scenarios, the two scenarios that will generate the highest net income for Fort Huachuca are Scenarios \#1A and \#2. The net income difference between Scenarios \#1A and \#2 is $\$ 1,000$ and their ROIs differ by just three years. Scenario \#1B generates a net income of $\$ 16,000$, which is $\$ 38,000$ less than the incomes produced by $\# 1 \mathrm{~A}$ and \#2; Scenario \#3 has a net income of $\$ 41,000$, which is $\$ 10,000$ less than either \#1A or \#2 incomes.

More specifically, while \#1A has higher income, \#1A also has higher collection costs and although \#2 collection costs are lower than those of \#1A, \#2 also generates lower income. Thus, the costs for both scenarios result in similar incomes. Although the marginal rate of return per investment is highest for Scenario \#3 (because it proposes recycling only from the buildings that generate the greatest numbers of recyclables), Scenarios \#1 and \#2 -generate more revenue because they propose collecting more recyclables from more buildings. 
Finally, Scenario \#1B, which requires the greatest investment, offers the lowest returns and has the highest ROI. This finding is because the costs in Scenario \#1B include all the implementation and maintenance expenses required to set up and operate an in-house recycling facility.

For more detail on these cost calculations, see this report's Appendix.

Table 13. ROI summary for collection scenarios (ERDC-CERL).

\begin{tabular}{|c|c|c|c|c|}
\hline Input Variables & $\begin{array}{l}\text { Scenario \#1A: } \\
\text { Collection } \\
\text { from All Bldgs } \\
\text { (320 bldgs.) }\end{array}$ & $\begin{array}{l}\text { Scenario \#1B: } \\
\text { Collection } \\
\text { from All Bldgs. } \\
\text { (in-house } \\
\text { recycling; } 320 \\
\text { bldgs.) }\end{array}$ & $\begin{array}{l}\text { Scenario \#2: } \\
\text { Collection by } \\
\text { Bldg. Type. } \\
\text { (93 bldgs.) }\end{array}$ & $\begin{array}{l}\text { Scenario \#3: } \\
\text { Collection from } \\
\text { Specific Bldgs. } \\
\text { (25 bldgs.) }\end{array}$ \\
\hline ROI (years) & 8.14 & 35.01 & 5.16 & 4.25 \\
\hline Gross annual savings & $\$ 207,000$ & $\$ 207,000$ & $\$ 157,000$ & $\$ 116,000$ \\
\hline Annual cost & $\$ 155,000$ & $\$ 191,000$ & $\$ 106,000$ & $\$ 75,000$ \\
\hline $\begin{array}{r}\text { NET INCOME (avoided } \\
\text { costs \& savings) }\end{array}$ & $\$ 103,000$ & $\$ 16,000$ & $\$ 51,000$ & $\$ 41,000$ \\
\hline $\begin{array}{r}\text { NET ANNUAL INCOME } \\
\text { PER BLDG }\end{array}$ & $\$ 322$ & $\$ 50$ & $\$ 548$ & $\$ 1,640$ \\
\hline $\begin{array}{l}\text { Annual recycling } \\
\text { (ton/year) }\end{array}$ & 1,025 & 1,025 & 776 & 590 \\
\hline $\begin{array}{l}\text { Value of recyclables ( } 70 \% \\
\text { capture) } \\
\text { Cost of containers \& ma- } \\
\text { chinery (indoors \& out- } \\
\text { doors) }\end{array}$ & $\$ 171,000$ & $\$ 171,000$ & $\$ 129,000$ & $\$ 95,000$ \\
\hline $\begin{array}{l}\text { Labor cost (to place new } \\
\text { containers) } \\
\text { Connection to utilities at } \\
\text { site }\end{array}$ & $\begin{array}{r}\$ 19,000 \\
\text { N/A }\end{array}$ & $\begin{array}{l}\$ 19,000 \\
\$ 30,000\end{array}$ & $\begin{array}{r}\$ 9,600 \\
N / A\end{array}$ & $\begin{array}{r}\$ 4,800 \\
N / A\end{array}$ \\
\hline Contracting & $\$ 14,000$ & $\$ 14,000$ & $\$ 14,000$ & $\$ 14,000$ \\
\hline $\begin{array}{l}\text { Outreach (initiating recy- } \\
\text { cling program) } \\
\text { Labels (for new contain- } \\
\text { ers) }\end{array}$ & $\begin{array}{l}\$ 20,000 \\
\$ 98,000\end{array}$ & $\begin{array}{l}\$ 20,000 \\
\$ 98,000\end{array}$ & $\$ 58,000$ & $\begin{array}{l}\$ 20,000 \\
\$ 39,000\end{array}$ \\
\hline ONE TIME COSTS & $\$ 421,000$ & $\$ 571,000$ & $\$ 258,600$ & $\$ 173,800$ \\
\hline $\begin{array}{l}\text { Labor } \\
\text { O\&M Labor Gov't (full- } \\
\text { time) }\end{array}$ & $\begin{array}{r}\$ 43,200 \\
N / A\end{array}$ & $\begin{array}{r}\$ 43,200 \\
\$ 120,000\end{array}$ & $\$ 28,800$ & $\$ 14,400$ \\
\hline Outreach & $\$ 19,000$ & $\$ 19,000$ & $\$ 7,200$ & $\$ 7,200$ \\
\hline Hauling Costs & $\$ 93,000$ & N/A & $\$ 70,000$ & $\$ 53,000$ \\
\hline $\begin{array}{l}\text { Additional Costs (hauling } \\
\text { recyclables) }\end{array}$ & $\mathrm{N} / \mathrm{A}$ & $\$-$ & $\mathrm{N} / \mathrm{A}$ & N/A \\
\hline
\end{tabular}




\begin{tabular}{|c|c|c|c|c|}
\hline Input Variables & $\begin{array}{l}\text { Scenario \#1A: } \\
\text { Collection } \\
\text { from All Bldgs } \\
\text { (320 bldgs.) }\end{array}$ & $\begin{array}{l}\text { Scenario \#1B: } \\
\text { Collection } \\
\text { from All BIdgs. } \\
\text { (in-house } \\
\text { recycling; } 320 \\
\text { bldgs.) }\end{array}$ & $\begin{array}{l}\text { Scenario \#2: } \\
\text { Collection by } \\
\text { Bldg. Type. } \\
\text { (93 bldgs.) }\end{array}$ & $\begin{array}{l}\text { Scenario \#3: } \\
\text { Collection from } \\
\text { Specific Bldgs. } \\
\text { (25 bldgs.) }\end{array}$ \\
\hline Liquid Fuels & N/A & $\$ 8,125$ & N/A & $\mathrm{N} / \mathrm{A}$ \\
\hline ANNUAL COSTS & $\$ 155,200$ & $\$ 190,325$ & $\$ 106,000$ & $\$ 74,600$ \\
\hline Hauling Costs & N/A & $\$-$ & N/A & $\mathrm{N} / \mathrm{A}$ \\
\hline Tipping Fees & $\$ 36,000$ & $\$ 36,000$ & $\$ 27,000$ & $\$ 21,000$ \\
\hline AVOIDANCE COSTS & $\$ 36,000$ & $\$ 36,000$ & $\$ 27,000$ & $\$ 21,000$ \\
\hline
\end{tabular}

\subsection{Summary of scenario advantages and disadvantages}

Table 14 provides lists of the advantages and disadvantages for each of the different recycling scenarios.

Table 14. Recycling collection pros and cons, compared by scenario (ERDC-CERL).

\begin{tabular}{|c|c|c|}
\hline Scenario & Pros & Cons \\
\hline $1 \mathrm{~A}$ & $\begin{array}{l}\text { - Serves } 100 \% \text { of the } \\
\text { installation } \\
\text { - Maximum collection of } \\
\text { recyclables } \\
\text { - Highest net income }\end{array}$ & - High implementation cost \\
\hline $1 \mathrm{~B}$ & $\begin{array}{l}\text { - The recycling program } \\
\text { services } 100 \% \text { of the } \\
\text { installation for maximum } \\
\text { collection of recyclables }\end{array}$ & $\begin{array}{l}\text { - Highest implementation costs } \\
\text { - Longest ROI payback period } \\
\text { - Lowest net income } \\
\text { - Highest annual costs } \\
\text { - Lowest marginal return for } \\
\text { investment }\end{array}$ \\
\hline 2 & $\begin{array}{l}\text { - Highest gross annual savings } \\
\text { per building } \\
\text { - Consistency among building } \\
\text { types }\end{array}$ & - Low diversion rates \\
\hline 3 & $\begin{array}{l}\text { - Quickest ROI } \\
\text { - Greatest marginal return for } \\
\text { investment } \\
\text { - Lowest implementation costs } \\
\text { - Lowest annual costs }\end{array}$ & $\begin{array}{l}\text { - Lowest diversion rates } \\
\text { - Lowest income } \\
\text { - Lowest net income } \\
\text { - Inconsistent implementation } \\
\text { from a user perspective }\end{array}$ \\
\hline
\end{tabular}


A QRP would be feasible for Fort Huachuca by following Scenarios 1A, 2, or 3 , as described above. In selecting which plan to implement, the installation must balance diversion goals against potential revenue. Because the goal of an installation recycling program is to maximize diversion rates and generate enough revenue from the sale of recyclables to support its recycling program, Scenario \#1A: "Collection from All Buildings" is recommended for Fort Huachuca. This scenario proposes contractor-based, installation-wide recycling, (i.e., there are none of the expensive implementation costs associated with the running of an in-house recycling program). Scenario \#1A is recommended over Scenarios \# 2 and \# 3 because it has the potential for higher diversion rates and is likely to net greater total revenues for Fort Huachuca. In addition, Scenario \#1A will provide a consistent recycling experience across the installation.

However, if the Garrison would prefer gradually rolling out recycling, Scenario \# 3 is preferable because it is easiest to implement and offers the quickest payback and highest return per dollar invested. 


\section{Bibliography}

10 U.S.C. 2577. “Armed Forces - Disposal of Recyclable Materials.” In U.S. Code, 2006 Edition, Suppl. 4, Title 10. Washington, DC: U.S. Armed Forces, 2006.

32 CFR 172. "Disposition of Proceeds from DoD Sales of Surplus Property" (Part 172) of Title 32 (National Defense), Subtitle (A Department of Defense). Washington, DC: Department of Defense, 54 Federal Register 354832011.

40 CFR 246.100. "Scope" in Title 40 (Protection of Environment), Chapter I (EPA), Subchapter I (Solid Wastes), Part 246 (Source Separation for Materials Recovery Guidelines), Subpart B (Requirements and Recommended Procedures). Washington, DC: U.S. Environmental Protection Agency, 41 Federal Register 16952, 23 April 1976.

40 CFR 246.200. "High-Grade Paper Recovery." In Title 40 (Protection of Environment), Chapter I (EPA), Subchapter I (Solid Wastes), Part 246 (Source Separation for Materials Recovery Guidelines), Subpart B (Requirements and Recommended Procedures. Washington, DC: U.S. Environmental Protection Agency, 41 Federal Register 16952, 23 April 1976.

40 CFR 246.200-1, "High-Grade Paper Recovery, Requirements" (Part 200-1) in Title 40 (Protection of Environment), Chapter I (EPA), Subchapter I (Solid Wastes), Part 246 (Source Separation for Materials Recovery Guidelines), Subpart B (Requirements and Recommended Procedures). Washington, DC: U.S. Environmental Protection Agency, 41 Federal Register 16952, 23 April 1976.

AR 11-2. Army Managers' Internal Control Program. Washington, DC: Headquarters, Department of the Army, 4 January 2010.

AR 200-1. Environmental Protection and Enhancement. Washington, DC: U.S. Army Assistant Secretary of the Army, 21 February 1997 (updated 2007).

AR 420-1. Army Facilities Management, Facilities Engineering. Washington, DC: Headquarters Department of the Army, 12 February 2008 (Rapid Action Revision 2012).

AR 420-49. Utility Services. Washington, DC: U.S. Army, Heritage and Education Center, 19 September 2005 [rev.].

DoDFMR 700.14-R. "Reimbursable Operations Policy." In Volume 11a of Department of Defense Financial Management Regulation. Washington, DC: Under Secretary of Defense - Comptroller, 2014.

DoDI 4715.23. Integrated Recycling and Solid Waste Management. Washington, DC: Office of the Under Secretary of Defense for Acquisition, Technology, and Logistics, 24 October 2016.

EO 13834. Efficient Federal Operations. Washington, DC: Office of President Donald J. Trump, 17 May 2018. 
Resource and Recovery Act of 1976. Public Law (P.L.) 94-580. Washington, DC: $94^{\text {th }}$ U.S. Congress and President Gerald Ford, 1976.

U.S. Army. Qualified Recycling Program Handbook. Washington, DC: U.S. Army Headquarters, Assistant Chief of Staff Installation Management (ACSIM), November 2010. 


\section{Appendix A: General Method for Recyclable Material Projection}

\section{Quantity projections}

ERDC-CERL performed a detailed waste characterization at Fort Huachuca, with the goals of determining waste generation factors and quantities of materials available for recycling. These waste factors (or "intensities") were calculated for each building type and for each of the 19 waste types (paper, aluminum, plastics, etc.). The idea was to develop generation factors so that waste generation could be extrapolated across all installation buildings. Further, in order to compare waste generate between buildings of different sizes, the waste intensities were expressed per unit of occupied floor area (i.e., pounds per square foot per day).

After waste generation factors were calculated, they were applied to all the buildings at Fort Huachuca. In this way, the expected daily quantities generated for each waste type was calculated. Once calculations were completed, it became time to think strategically about where to focus recycling efforts. For example, it might be important to know which buildings are the top 20 generators of cardboard.

For Scenario \#1, recycling collection from all buildings, a spreadsheet model developed by ERDC-CERL gives a tally of the total quantity and value for each recycling commodity. For Scenarios \#2 and \#3, the spreadsheet prioritizes which buildings to service, based on expected recycling generation at each building. In addition, for Scenario \#2 the spreadsheet both groups and sums the generation of recyclables by building type (e.g., barracks or DFAC). This capability enables the user to determine which building types are the top generators of recycling. Scenario \# 3 , on the other hand, takes a more granular look, building by building, to determine and sort the list of buildings expected to generate the most recycling. After the buildings that are best for recycling in each scenario has been determined, then it is time to compute the potential material sales revenues possible for each scenario. 


\section{ROI calculations}

The ROI calculations in this report were performed with an additional spreadsheet model developed by ERDC-CERL in support of IMCOM's P2 program. Three types of costs go into this model, as listed below:

1. Detailed annual costs based on the current ways of doing business to address specific issues like waste management; these costs includes labor, utilities, repairs, waste disposal, etc.

2. Implementation costs for a proposed new process (in this case, implementing a recycling program); these costs include capital costs, equipment installation, and staff time for contracting and coordination.

3. Finally, projected annual costs and revenues for the proposed process.

To determine the simple payback time in years (i.e., how long will the new process take to pay back the initial investment), it is necessary to divide the net annual savings expected with the new process by the total of the new process's implementation costs.

\section{Scenario \#1 building list}

Table A1 lists the suggested number of interior and exterior recycling containers at each building that is included in Scenario \#1. ${ }^{25,}{ }^{26}$ The dark horizontal lines help to delineate each block. These container numbers were derived in the following ways:

- Each block must have at least one set of exterior collection containers (one each for cardboard, office paper, and commingled drink containers, and one for commingled plastic and aluminum drink containers).

- Each building must have at least one set of interior collection containers (a set here consists of one container for office paper and one container for commingled plastic and aluminum drink containers).

- Same number of exterior paper and drink bins per block of buildings.

\footnotetext{
25 This method of calculation and table data apply to both scenarios \#1A and \#1B.

26 This method of calculation applies to all scenarios.
} 
- Same number of interior paper and drink bins per building.

- Building types of general purpose warehouse (GPW), physical fitness facility (PFF), PX, and TEMF were assigned one set of interior bins per $5,000 \mathrm{ft}^{2}$ area.

- All other building types were assigned one set of interior bins per $2,000 \mathrm{ft}^{2}$ area.

Table A1. Scenario \#1 building list with number of recycling containers needed (ERDC-CERL, with building information provided by Fort Huachuca DPW).

\begin{tabular}{|c|c|c|c|c|c|c|c|c|}
\hline \multicolumn{4}{|c|}{ Building Info } & \multicolumn{5}{|c|}{ Containers } \\
\hline $\begin{array}{l}\text { Building } \\
\text { No. }\end{array}$ & $\begin{array}{l}\text { Bldg \# } \\
\text { Exten. }\end{array}$ & Organization & $\begin{array}{l}\text { Building } \\
\text { Type }\end{array}$ & $\begin{array}{l}\text { Exterior } \\
\text { Cardboard }\end{array}$ & $\begin{array}{l}\text { Exterior } \\
\text { Paper }\end{array}$ & $\begin{array}{l}\text { Exterior } \\
\text { Drink }\end{array}$ & $\begin{array}{l}\text { Interior } \\
\text { Paper }\end{array}$ & $\begin{array}{l}\text { Interior } \\
\text { Drink }\end{array}$ \\
\hline 15423 & & $\begin{array}{l}\text { SPORTSMANS } \\
\text { CENTER, FMWR }\end{array}$ & Office-Small & & 0 & 0 & 1 & 1 \\
\hline 15424 & & RANGE CONTROL & Office-Small & & 0 & 0 & 1 & 1 \\
\hline 15425 & & RANGE CONTROL & Office-Small & & 0 & 0 & 1 & 1 \\
\hline 15430 & & RANGE CONTROL & Office-Small & & 0 & 0 & 1 & 1 \\
\hline 15471 & & $\begin{array}{l}\text { GOLF COURSE, } \\
\text { FMWR }\end{array}$ & TEMF - T & & 0 & 0 & 1 & 1 \\
\hline 15472 & & $\begin{array}{l}\text { GOLF COURSE, } \\
\text { FMWR }\end{array}$ & TEMF & & 0 & 0 & 1 & 1 \\
\hline 15475 & & $\begin{array}{l}\text { GOLF COURSE, } \\
\text { FMWR }\end{array}$ & TEMF & & 0 & 0 & 1 & 1 \\
\hline 15476 & & $\begin{array}{l}\text { GOLF COURSE, } \\
\text { FMWR }\end{array}$ & TEMF & & 0 & 0 & 1 & 1 \\
\hline 15477 & & $\begin{array}{l}\text { MOUNTAIN VIEW } \\
\text { GOLF COURSE }\end{array}$ & TEMF & & 0 & 0 & 1 & 1 \\
\hline 15479 & & $\begin{array}{l}\text { MOUNTAIN VIEW } \\
\text { GOLF COURSE }\end{array}$ & PX & 2 & 1 & 1 & 2 & 2 \\
\hline 15482 & & $\begin{array}{l}\text { GOLF COURSE, } \\
\text { FMWR }\end{array}$ & TEMF & & 0 & 0 & 1 & 1 \\
\hline 15483 & & $\begin{array}{l}\text { GOLF COURSE, } \\
\text { FMWR }\end{array}$ & TEMF & & 0 & 0 & 1 & 1 \\
\hline 15491 & & $\begin{array}{l}\text { SHOPPETTE / MAIN } \\
\text { GATE }\end{array}$ & PX & 1 & 1 & 1 & 1 & 1 \\
\hline 21112 & & $\begin{array}{l}\text { Wayland Baptist } \\
\text { University }\end{array}$ & GIB & & 0 & 0 & 2 & 2 \\
\hline 21112 & & ACAP & GIB & 1 & 1 & 1 & 1 & 1 \\
\hline 21115 & & Public Affairs Office & Office-Small & 0 & 1 & 1 & 2 & 2 \\
\hline 21115 & & Public Affairs Office & Office-Small & & 0 & 0 & 1 & 1 \\
\hline 22208 & & $\begin{array}{l}\text { DPW, USAG FT } \\
\text { HUACHUCA }\end{array}$ & ARC & & 0 & 0 & 3 & 3 \\
\hline
\end{tabular}




\begin{tabular}{|c|c|c|c|c|c|c|c|c|}
\hline \multicolumn{4}{|c|}{ Building Info } & \multicolumn{5}{|c|}{ Containers } \\
\hline $\begin{array}{l}\text { Building } \\
\text { No. }\end{array}$ & $\begin{array}{l}\text { Bldg \# } \\
\text { Exten. }\end{array}$ & Organization & $\begin{array}{l}\text { Building } \\
\text { Type }\end{array}$ & $\begin{array}{l}\text { Exterior } \\
\text { Cardboard }\end{array}$ & $\begin{array}{l}\text { Exterior } \\
\text { Paper }\end{array}$ & $\begin{array}{l}\text { Exterior } \\
\text { Drink }\end{array}$ & $\begin{array}{l}\text { Interior } \\
\text { Paper }\end{array}$ & $\begin{array}{l}\text { Interior } \\
\text { Drink }\end{array}$ \\
\hline 22208 & & HHD 111 MI BDE & BDEHQ & & 0 & 0 & 2 & 2 \\
\hline 22208 & & 6TH CID REG & $\mathrm{COF}$ & & 0 & 0 & 1 & 1 \\
\hline 22208 & & ACCAPG & Office-Medium & & 1 & 1 & 4 & 4 \\
\hline 22212 & & USAG FT HUACHUCA & ARC & & 0 & 0 & 1 & 1 \\
\hline 22214 & & MWR & Office-Medium & & 1 & 1 & 4 & 4 \\
\hline 22214 & & CPAC (MER Branch) & Office-Small & & 1 & 1 & 1 & 1 \\
\hline 22216 & & $\begin{array}{l}\text { REAL PROPERTY, } \\
\text { DPW }\end{array}$ & Office-Medium & 1 & 1 & 1 & 6 & 6 \\
\hline 22320 & & $\begin{array}{l}\text { USA CPAC FT } \\
\text { HUACHUCA }\end{array}$ & Office-Medium & 1 & 1 & 1 & 6 & 6 \\
\hline 22322 & & $\begin{array}{l}\text { USA CPAC FT } \\
\text { HUACHUCA }\end{array}$ & GIB & & 0 & 0 & 1 & 1 \\
\hline 22324 & & $\begin{array}{l}\text { NEC Command } \\
\text { Center }\end{array}$ & INFOSYS & & 0 & 0 & 1 & 1 \\
\hline 22324 & & $\begin{array}{l}\text { Judge Advocate } \\
\text { Generals }\end{array}$ & Office-Small & & 0 & 0 & 1 & 1 \\
\hline 22326 & & Safety Office & Office-Small & 1 & 1 & 1 & 1 & 1 \\
\hline 22328 & & $\begin{array}{l}\text { EQUAL } \\
\text { EMPLOYMENT } \\
\text { OPPORTUNITY }\end{array}$ & Office-Small & & 0 & 0 & 2 & 2 \\
\hline 22334 & & USA AVN COE & BNHQ & & 1 & 1 & 2 & 2 \\
\hline 22336 & & 18TH MP DET & $\mathrm{COF}$ & & 0 & 0 & 2 & 2 \\
\hline 22404 & & $\begin{array}{l}\text { TDY STUDENTS- } \\
\text { BILLET LOAD } \\
\text { (SCHOOL CODE } \\
307)\end{array}$ & UEPH & & 0 & 0 & 1 & 1 \\
\hline 22408 & & $\begin{array}{l}\text { FLD OFC FT } \\
\text { HUACHUCA }\end{array}$ & GPW & & 0 & 0 & 1 & 1 \\
\hline 22408 & & $\begin{array}{l}\text { DOL FT HUACHUCA } \\
\text { AZ }\end{array}$ & GPW & & 0 & 0 & 1 & 1 \\
\hline 22408 & & $\begin{array}{l}\text { DOL FT HUACHUCA } \\
\text { AZ }\end{array}$ & Office-Small & & 0 & 0 & 2 & 2 \\
\hline 22408 & & $\begin{array}{l}\text { FLD OFC FT } \\
\text { HUACHUCA }\end{array}$ & Office-Small & & 0 & 0 & 1 & 1 \\
\hline 22408 & & $\begin{array}{l}\text { FLD OFC FT } \\
\text { HUACHUCA } \\
\end{array}$ & Office-Small & & 0 & 0 & 1 & 1 \\
\hline 22414 & & $\begin{array}{l}\text { TDY STUDENTS- } \\
\text { BILLET LOAD } \\
\text { (SCHOOL CODE } \\
307)\end{array}$ & GIB & & 1 & 1 & 4 & 4 \\
\hline 22414 & & $\begin{array}{l}\text { REAL PROPERTY, } \\
\text { DPW }\end{array}$ & GPW & 1 & 1 & 1 & 2 & 2 \\
\hline 22414 & & $\begin{array}{l}\text { REAL PROPERTY, } \\
\text { DPW }\end{array}$ & GPW & & 0 & 0 & 1 & 1 \\
\hline
\end{tabular}




\begin{tabular}{|c|c|c|c|c|c|c|c|c|}
\hline \multicolumn{4}{|c|}{ Building Info } & \multicolumn{5}{|c|}{ Containers } \\
\hline $\begin{array}{l}\text { Building } \\
\text { No. }\end{array}$ & $\begin{array}{l}\text { Bldg \# } \\
\text { Exten. }\end{array}$ & Organization & $\begin{array}{l}\text { Building } \\
\text { Type }\end{array}$ & $\begin{array}{l}\text { Exterior } \\
\text { Cardboard }\end{array}$ & $\begin{array}{l}\text { Exterior } \\
\text { Paper }\end{array}$ & $\begin{array}{l}\text { Exterior } \\
\text { Drink }\end{array}$ & $\begin{array}{l}\text { Interior } \\
\text { Paper }\end{array}$ & $\begin{array}{l}\text { Interior } \\
\text { Drink }\end{array}$ \\
\hline 22414 & & $\begin{array}{l}\text { TDY STUDENTS- } \\
\text { BILLET LOAD } \\
\text { (SCHOOL CODE } \\
307)\end{array}$ & GPW & & 0 & 0 & 1 & 1 \\
\hline 22414 & & $\begin{array}{l}\text { DPW, USAG FT } \\
\text { HUACHUCA }\end{array}$ & GPW & & 0 & 0 & 1 & 1 \\
\hline 22414 & & $\begin{array}{l}\text { ARMY SUBSTANCE } \\
\text { ABUSE PROGRAM }\end{array}$ & $\mathrm{OHC}$ & & 1 & 1 & 4 & 4 \\
\hline 22418 & & $\begin{array}{l}\text { REAL PROPERTY, } \\
\text { DPW }\end{array}$ & Office-Small & & 0 & 0 & 2 & 2 \\
\hline 22422 & & $\begin{array}{l}\text { DPW, USAG FT } \\
\text { HUACHUCA }\end{array}$ & Office-Medium & & 1 & 1 & 6 & 6 \\
\hline 22422 & & $\begin{array}{l}\text { DOL FT HUACHUCA } \\
\text { AZ }\end{array}$ & Office-Small & & 0 & 0 & 1 & 1 \\
\hline 22526 & & OPS \& MAINT, DPW & Office-Medium & 1 & 1 & 1 & 4 & 4 \\
\hline 22528 & & $\begin{array}{l}\text { DPW, USAG FT } \\
\text { HUACHUCA }\end{array}$ & ARC & & 0 & 0 & 4 & 4 \\
\hline 22530 & & $\begin{array}{l}\text { DPW, USAG FT } \\
\text { HUACHUCA }\end{array}$ & TEMF & 1 & 1 & 1 & 3 & 3 \\
\hline 22534 & & $\begin{array}{l}\text { DPW, USAG FT } \\
\text { HUACHUCA }\end{array}$ & GPW & & 0 & 0 & 1 & 1 \\
\hline 22542 & & $\begin{array}{l}\text { DPW, USAG FT } \\
\text { HUACHUCA }\end{array}$ & GPW & & 0 & 0 & 1 & 1 \\
\hline 22543 & & $\begin{array}{l}\text { DPW, USAG FT } \\
\text { HUACHUCA }\end{array}$ & GPW & & 0 & 0 & 1 & 1 \\
\hline 30009 & & $\begin{array}{l}\text { FT HUACHUCA VET } \\
\text { BRANCH }\end{array}$ & $\mathrm{OHC}$ & & 0 & 0 & 1 & 1 \\
\hline 30010 & & $\begin{array}{l}\text { FT HUACHUCA VET } \\
\text { BRANCH }\end{array}$ & $\mathrm{OHC}$ & 1 & 1 & 1 & 1 & 1 \\
\hline 30015 & & USDA-Forest Service & $\mathrm{OHC}$ & & 0 & 0 & 1 & 1 \\
\hline 30018 & & $\begin{array}{l}\text { ENG/HOUSE MNT } \\
\text { (HVAC) }\end{array}$ & TEMF & & 0 & 0 & 1 & 1 \\
\hline 30020 & & $\begin{array}{l}\text { SUPPLY / YARD 8, } \\
\text { DPW }\end{array}$ & GPW & & 0 & 0 & 1 & 1 \\
\hline 30023 & & $\begin{array}{l}\text { DPW, USAG FT } \\
\text { HUACHUCA }\end{array}$ & GPW & & 0 & 0 & 1 & 1 \\
\hline 30024 & & $\begin{array}{l}\text { REAL PROPERTY, } \\
\text { DPW }\end{array}$ & GPW & & 0 & 0 & 1 & 1 \\
\hline 30031 & & EMCOR & TEMF & & 0 & 0 & 1 & 1 \\
\hline 30033 & & EMCOR & TEMF & & 0 & 0 & 1 & 1 \\
\hline 30113 & & $\begin{array}{l}\text { CTR USA INT CEN \& } \\
\text { FT }\end{array}$ & GPW & & 0 & 0 & 1 & 1 \\
\hline 30114 & & $\begin{array}{l}\text { USA OPTEC TEXCOM } \\
\text { IEWT DIR }\end{array}$ & TEMF & & 0 & 0 & 1 & 1 \\
\hline 30115 & & GAN & TEMF & 1 & 1 & 1 & 1 & 1 \\
\hline
\end{tabular}




\begin{tabular}{|c|c|c|c|c|c|c|c|c|}
\hline \multicolumn{4}{|c|}{ Building Info } & \multicolumn{5}{|c|}{ Containers } \\
\hline $\begin{array}{l}\text { Building } \\
\text { No. }\end{array}$ & $\begin{array}{l}\text { Bldg \# } \\
\text { Exten. }\end{array}$ & Organization & $\begin{array}{l}\text { Building } \\
\text { Type }\end{array}$ & $\begin{array}{l}\text { Exterior } \\
\text { Cardboard }\end{array}$ & $\begin{array}{l}\text { Exterior } \\
\text { Paper }\end{array}$ & $\begin{array}{l}\text { Exterior } \\
\text { Drink }\end{array}$ & $\begin{array}{l}\text { Interior } \\
\text { Paper }\end{array}$ & $\begin{array}{l}\text { Interior } \\
\text { Drink }\end{array}$ \\
\hline 30118 & & $\begin{array}{l}\text { DOL FT HUACHUCA } \\
\text { AZ }\end{array}$ & GPW & & 0 & 0 & 2 & 2 \\
\hline 30118 & & $\begin{array}{l}\text { DPW, USAG FT } \\
\text { HUACHUCA }\end{array}$ & GPW & & 0 & 0 & 1 & 1 \\
\hline 30118 & & 111TH MI BDE & GPW & & 0 & 0 & 1 & 1 \\
\hline 30118 & & $\begin{array}{l}\text { FT HUACHUCA } \\
\text { MUSEUM, FMWR }\end{array}$ & GPW & & 0 & 0 & 1 & 1 \\
\hline 30134 & & EMCOR & TEMF & & 0 & 0 & 2 & 2 \\
\hline 30138 & & CO D $306 \mathrm{MI}$ BN & GIB & & 1 & 1 & 3 & 3 \\
\hline 30157 & & MWR & Religious & & 0 & 0 & 1 & 1 \\
\hline 31008 & & MAIN EXCHANGE & GPW & & 0 & 0 & 1 & 1 \\
\hline 31008 & & $\begin{array}{l}\text { DPW, USAG FT } \\
\text { HUACHUCA }\end{array}$ & GPW & & 0 & 0 & 1 & 1 \\
\hline 31013 & & $\begin{array}{l}\text { DES, USAG FT } \\
\text { HUACHUCA }\end{array}$ & GIB & & 1 & 1 & 2 & 2 \\
\hline 31022 & & 25 MP DET & $\mathrm{COF}$ & & 1 & 1 & 3 & 3 \\
\hline 31032 & & USAG HHC CO HQ & $\mathrm{COF}$ & & 0 & 0 & 1 & 1 \\
\hline 31043 & & $\begin{array}{l}\text { DES, USAG FT } \\
\text { HUACHUCA }\end{array}$ & ARC & & 0 & 0 & 1 & 1 \\
\hline 31044 & & $\begin{array}{l}\text { OFFICE OF } \\
\text { INSPECTOR } \\
\text { GENERAL }\end{array}$ & Office-Small & 1 & 1 & 1 & 1 & 1 \\
\hline 31114 & & $\begin{array}{l}\text { DPW, USAG FT } \\
\text { HUACHUCA }\end{array}$ & TEMF & & 0 & 0 & 1 & 1 \\
\hline 31122 & & $\begin{array}{l}\text { DES, USAG FT } \\
\text { HUACHUCA }\end{array}$ & ARC & & 0 & 0 & 1 & 1 \\
\hline 31122 & & USAG FT HUACHUCA & ARC & & 0 & 0 & 1 & 1 \\
\hline 31122 & & 18TH MP DET & $\mathrm{COF}$ & 1 & 1 & 1 & 3 & 3 \\
\hline 31122 & & MPI & Office-Medium & & 1 & 1 & 5 & 5 \\
\hline 31122 & & DPTMS & Office-Small & & 1 & 1 & 3 & 3 \\
\hline 31122 & & DACP & Office-Small & & 0 & 0 & 1 & 1 \\
\hline 31122 & & $\begin{array}{l}\text { Physical Security } \\
\text { (DES) }\end{array}$ & Office-Small & & 0 & 0 & 1 & 1 \\
\hline 31122 & & UPH HOUSING, DPW & UEPH & 1 & 2 & 2 & 10 & 10 \\
\hline 41305 & & $\begin{array}{l}\text { FT HUACHUCA } \\
\text { MUSEUM, FMWR }\end{array}$ & Religious & & 0 & 0 & 3 & 3 \\
\hline 41330 & & ADJUTANT GENERAL & Office-Medium & 1 & 1 & 1 & 4 & 4 \\
\hline 41401 & & $\begin{array}{l}\text { FT HUACHUCA } \\
\text { MUSEUM, FMWR }\end{array}$ & Religious & & 1 & 1 & 4 & 4 \\
\hline 41402 & & USAG CMD HQ & Office-Small & & 0 & 0 & 2 & 2 \\
\hline 41407 & & $\begin{array}{l}\text { USAG RESOURCE } \\
\text { MANAGEMENT }\end{array}$ & GPW & & 0 & 0 & 1 & 1 \\
\hline
\end{tabular}




\begin{tabular}{|c|c|c|c|c|c|c|c|c|}
\hline \multicolumn{4}{|c|}{ Building Info } & \multicolumn{5}{|c|}{ Containers } \\
\hline $\begin{array}{l}\text { Building } \\
\text { No. }\end{array}$ & $\begin{array}{l}\text { Bldg \# } \\
\text { Exten. }\end{array}$ & Organization & $\begin{array}{l}\text { Building } \\
\text { Type }\end{array}$ & $\begin{array}{l}\text { Exterior } \\
\text { Cardboard }\end{array}$ & $\begin{array}{l}\text { Exterior } \\
\text { Paper }\end{array}$ & $\begin{array}{l}\text { Exterior } \\
\text { Drink }\end{array}$ & $\begin{array}{l}\text { Interior } \\
\text { Paper }\end{array}$ & $\begin{array}{l}\text { Interior } \\
\text { Drink }\end{array}$ \\
\hline 41407 & & $\begin{array}{l}\text { USAG RESOURCE } \\
\text { MANAGEMENT }\end{array}$ & Office-Small & & 0 & 0 & 2 & 2 \\
\hline 41408 & & DRM ORG E & Office-Medium & 1 & 1 & 1 & 5 & 5 \\
\hline 41411 & & $\begin{array}{l}\text { US ARMY } \\
\text { INTELLIGENCE } \\
\text { MUSEUM }\end{array}$ & Religious & & 1 & 1 & 3 & 3 \\
\hline 41412 & & CO D $306 \mathrm{Ml} \mathrm{BN}$ & GIB & & 1 & 1 & 5 & 5 \\
\hline 41415 & & $\begin{array}{l}\text { DOL FT HUACHUCA } \\
\text { AZ }\end{array}$ & Office-Small & 1 & 1 & 1 & 2 & 2 \\
\hline 41415 & & $\begin{array}{l}\text { TRAINING AND } \\
\text { DEVELOPMENT }\end{array}$ & Office-Small & & 0 & 0 & 2 & 2 \\
\hline 41416 & & CO D $306 \mathrm{MI} B N$ & GIB & & 2 & 2 & 6 & 6 \\
\hline 41418 & & $\begin{array}{l}\text { TRADOC-Capability } \\
\text { Mgr. for Intel Sensor }\end{array}$ & GPW & & 0 & 0 & 1 & 1 \\
\hline 41418 & & $\begin{array}{l}\text { OCMI - Office of the } \\
\text { Chief Mil Intel }\end{array}$ & GPW & & 0 & 0 & 1 & 1 \\
\hline 41418 & & $\begin{array}{l}\text { TRADOC-Capability } \\
\text { Mgr for Intel Sensor }\end{array}$ & Office-Medium & & 1 & 1 & 4 & 4 \\
\hline 41419 & & $\begin{array}{l}\text { TRADOC-Capability } \\
\text { Mgr for Intel Sensor }\end{array}$ & Office-Medium & & 1 & 1 & 7 & 7 \\
\hline 41420 & & 111TH MI BDE & BDEHQ & 1 & 1 & 1 & 2 & 2 \\
\hline 41420 & & 111TH MI BDE & GPW & & 0 & 0 & 1 & 1 \\
\hline 41420 & & $\begin{array}{l}\text { MPO (Defense } \\
\text { Military Pay) }\end{array}$ & Office-Medium & & 1 & 1 & 4 & 4 \\
\hline 41420 & & USAG FT HUACHUCA & Office-Small & & 0 & 0 & 1 & 1 \\
\hline 41421 & & $\begin{array}{l}\text { DHR, USAG FT } \\
\text { HUACHUCA }\end{array}$ & GPW & & 0 & 0 & 2 & 2 \\
\hline 41421 & & ACAP & Office-Small & & 0 & 0 & 1 & 1 \\
\hline 45001 & & $\begin{array}{l}\text { RAYMOND W. BLISS } \\
\text { CLINIC }\end{array}$ & $\begin{array}{l}\text { Healthcare - } \\
\text { Hospital }\end{array}$ & 2 & 9 & 9 & 44 & 44 \\
\hline 45004 & & EMCOR & GPW & & 0 & 0 & 1 & 1 \\
\hline 45005 & & $\begin{array}{l}\text { W3ZU USA DENTAL } \\
\text { ACT }\end{array}$ & $\mathrm{OHC}$ & 1 & 1 & 1 & 6 & 6 \\
\hline 45006 & & $\begin{array}{l}\text { RAYMOND W. BLISS } \\
\text { CLINIC }\end{array}$ & $\mathrm{OHC}$ & & 1 & 1 & 7 & 7 \\
\hline 45022 & & Medical Warehouse & GPW & & 0 & 0 & 3 & 3 \\
\hline 45103 & & Myer School & GIB & 2 & 3 & 3 & 15 & 15 \\
\hline 46802 & & Community Center & Community & 2 & 3 & 3 & 15 & 15 \\
\hline 47121 & & Elementary School & GIB & 2 & 3 & 3 & 15 & 15 \\
\hline 48101 & & CDC, FMWR & $\mathrm{CDC}$ & 2 & 2 & 2 & 11 & 11 \\
\hline 48228 & & Middle School & & 2 & 3 & 3 & 15 & 15 \\
\hline
\end{tabular}




\begin{tabular}{|c|c|c|c|c|c|c|c|c|}
\hline \multicolumn{4}{|c|}{ Building Info } & \multicolumn{5}{|c|}{ Containers } \\
\hline $\begin{array}{l}\text { Building } \\
\text { No. }\end{array}$ & $\begin{array}{l}\text { Bldg \# } \\
\text { Exten. }\end{array}$ & Organization & $\begin{array}{l}\text { Building } \\
\text { Type }\end{array}$ & $\begin{array}{l}\text { Exterior } \\
\text { Cardboard }\end{array}$ & $\begin{array}{l}\text { Exterior } \\
\text { Paper }\end{array}$ & $\begin{array}{l}\text { Exterior } \\
\text { Drink }\end{array}$ & $\begin{array}{l}\text { Interior } \\
\text { Paper }\end{array}$ & $\begin{array}{l}\text { Interior } \\
\text { Drink }\end{array}$ \\
\hline 49013 & & YOUTH SERVICE & PFF & 2 & 1 & 1 & 4 & 4 \\
\hline 49055 & & CDC, FMWR & $\mathrm{CDC}$ & 2 & 2 & 2 & 8 & 8 \\
\hline 50010 & & ARMY CMTY SVC & Office-Medium & 1 & 1 & 1 & 4 & 4 \\
\hline 50025 & & $\begin{array}{l}\text { DPW, USAG FT } \\
\text { HUACHUCA }\end{array}$ & Religious & & 0 & 0 & 1 & 1 \\
\hline 51001 & & $\begin{array}{l}\text { BN 5TH BN, 104TH } \\
\text { REGT }\end{array}$ & BNHQ & 1 & 1 & 1 & 6 & 6 \\
\hline 51001 & & $\begin{array}{l}\text { BND GEN FORCE } \\
\text { ARMY BA }\end{array}$ & GIB & & 2 & 2 & 5 & 5 \\
\hline 51001 & & UPH HOUSING, DPW & $\begin{array}{l}\text { Training } \\
\text { Barracks }\end{array}$ & & 2 & 2 & 10 & 10 \\
\hline 51005 & & HHC USAICoE & BNHQ & & 1 & 1 & 4 & 4 \\
\hline 51005 & & 902nd MI GP & $\mathrm{COF}$ & & 0 & 0 & 2 & 2 \\
\hline 51005 & & CO E 2-13 Avn Regt & $\mathrm{COF}$ & & 0 & 0 & 1 & 1 \\
\hline 51005 & & Learning Innovation & GIB & & 1 & 1 & 3 & 3 \\
\hline 51005 & & ARNG & Office-Small & & 1 & 1 & 3 & 3 \\
\hline 51005 & & ITRADS & Office-Small & & 0 & 0 & 2 & 2 \\
\hline 51005 & & $\begin{array}{l}\text { Judge Advocate } \\
\text { Generals }\end{array}$ & Office-Small & & 0 & 0 & 1 & 1 \\
\hline 51005 & & $\begin{array}{l}\text { W3ZU USA DENTAL } \\
\text { ACT }\end{array}$ & $\mathrm{OHC}$ & & 0 & 0 & 1 & 1 \\
\hline 51005 & & 111TH MI BDE & $\begin{array}{l}\text { Training } \\
\text { Barracks }\end{array}$ & 1 & 9 & 9 & 45 & 45 \\
\hline 51005 & & CO E 2-13 Avn Regt & $\begin{array}{l}\text { Training } \\
\text { Barracks }\end{array}$ & & 5 & 5 & 27 & 27 \\
\hline 51028 & & FIRE STATION \#1 & TEMF & & 1 & 1 & 1 & 1 \\
\hline 51101 & & MEDDAC & $\mathrm{OHC}$ & & 1 & 1 & 4 & 4 \\
\hline 51102 & & $\begin{array}{l}\text { USA TRIAL DEF SVC } \\
\text { FT HUACHUCA }\end{array}$ & Office-Medium & 1 & 1 & 1 & 4 & 4 \\
\hline 51201 & & KINO CHAPEL & Religious & & 1 & 1 & 3 & 3 \\
\hline 51301 & & MWR & Religious & 1 & 3 & 3 & 14 & 14 \\
\hline 51406 & & $\begin{array}{l}\text { DES, USAG FT } \\
\text { HUACHUCA }\end{array}$ & GPW & & 0 & 0 & 1 & 1 \\
\hline 51419 & & $\begin{array}{l}\text { DES, USAG FT } \\
\text { HUACHUCA }\end{array}$ & GPW & & 0 & 0 & 1 & 1 \\
\hline 51420 & & $\begin{array}{l}\text { ACT USA SIGNAL } \\
\text { NETWOR }\end{array}$ & GPW & & 0 & 0 & 1 & 1 \\
\hline 51421 & & $\begin{array}{l}\text { MISSION SUPPORT } \\
\text { DIRECTORATE }\end{array}$ & GPW & & 0 & 0 & 1 & 1 \\
\hline 51424 & & $\begin{array}{l}\text { REAL PROPERTY, } \\
\text { DPW }\end{array}$ & TEMF & & 0 & 0 & 1 & 1 \\
\hline
\end{tabular}




\begin{tabular}{|c|c|c|c|c|c|c|c|c|}
\hline \multicolumn{4}{|c|}{ Building Info } & \multicolumn{5}{|c|}{ Containers } \\
\hline $\begin{array}{l}\text { Building } \\
\text { No. }\end{array}$ & $\begin{array}{l}\text { Bldg \# } \\
\text { Exten. }\end{array}$ & Organization & $\begin{array}{l}\text { Building } \\
\text { Type }\end{array}$ & $\begin{array}{l}\text { Exterior } \\
\text { Cardboard }\end{array}$ & $\begin{array}{l}\text { Exterior } \\
\text { Paper }\end{array}$ & $\begin{array}{l}\text { Exterior } \\
\text { Drink }\end{array}$ & $\begin{array}{l}\text { Interior } \\
\text { Paper }\end{array}$ & $\begin{array}{l}\text { Interior } \\
\text { Drink }\end{array}$ \\
\hline 51427 & & $\begin{array}{l}\text { REAL PROPERTY, } \\
\text { DPW }\end{array}$ & TEMF & & 0 & 0 & 1 & 1 \\
\hline 51428 & & $\begin{array}{l}\text { REAL PROPERTY, } \\
\text { DPW }\end{array}$ & TEMF & & 0 & 0 & 1 & 1 \\
\hline 51432 & & $\begin{array}{l}\text { REAL PROPERTY, } \\
\text { DPW }\end{array}$ & TEMF & & 0 & 0 & 1 & 1 \\
\hline 51437 & & $\begin{array}{l}\text { BDE HHC THEAT } \\
\text { TAC SIG }\end{array}$ & GPW & & 0 & 0 & 1 & 1 \\
\hline 51450 & & AAFES & TEMF & & 0 & 0 & 2 & 2 \\
\hline 51451 & & $11 \mathrm{SC} B D E \mathrm{HHC}$ & TEMF & 2 & 2 & 2 & 1 & 1 \\
\hline 51452 & & $\begin{array}{l}\text { REAL PROPERTY, } \\
\text { DPW }\end{array}$ & GIB & & 0 & 0 & 1 & 1 \\
\hline 51453 & & $\begin{array}{l}\text { REAL PROPERTY, } \\
\text { DPW }\end{array}$ & TEMF & & 0 & 0 & 1 & 1 \\
\hline 51454 & & $\begin{array}{l}\text { REAL PROPERTY, } \\
\text { DPW }\end{array}$ & Office-Small & & 0 & 0 & 1 & 1 \\
\hline 51455 & & $\begin{array}{l}\text { REAL PROPERTY, } \\
\text { DPW }\end{array}$ & Office-Small & & 0 & 0 & 1 & 1 \\
\hline 51456 & & $\begin{array}{l}\text { REAL PROPERTY, } \\
\text { DPW }\end{array}$ & TEMF & & 0 & 0 & 1 & 1 \\
\hline 51457 & & $\begin{array}{l}\text { REAL PROPERTY, } \\
\text { DPW }\end{array}$ & TEMF & & 0 & 0 & 1 & 1 \\
\hline 51458 & & $\begin{array}{l}\text { REAL PROPERTY, } \\
\text { DPW }\end{array}$ & TEMF & & 0 & 0 & 1 & 1 \\
\hline 52008 & & $\begin{array}{l}\text { CRAFT CENTER, } \\
\text { FMWR }\end{array}$ & TEMF & 1 & 1 & 1 & 2 & 2 \\
\hline 52010 & & $\begin{array}{l}\text { BOWLING CENTER, } \\
\text { FMWR }\end{array}$ & PFF & 1 & 1 & 1 & 5 & 5 \\
\hline 52025 & & GAME STOP & PX & 1 & 0 & 0 & 1 & 1 \\
\hline 52030 & & MAIN EXCHANGE & PX & 2 & 3 & 3 & 15 & 15 \\
\hline 52038 & & $\begin{array}{l}\text { SHOPPETTE / } \\
\text { CLASS VI }\end{array}$ & PX & 2 & 0 & 0 & 1 & 1 \\
\hline 52040 & & $\begin{array}{l}\text { POST OFFICE FT } \\
\text { HUACHUCA }\end{array}$ & Office-Small & & 0 & 0 & 2 & 2 \\
\hline 52045 & & Launderette & PX & 1 & 0 & 0 & 1 & 1 \\
\hline 52048 & & $\begin{array}{l}\text { PX FURNITURE / } \\
\text { OUTDOOR LIVING }\end{array}$ & PX & 2 & 0 & 0 & 3 & 3 \\
\hline 52056 & & $\begin{array}{l}\text { CYS SERVICES, } \\
\text { FMWR }\end{array}$ & $\mathrm{CDC}$ & 2 & 2 & 2 & 12 & 12 \\
\hline 52060 & & MAIN CHAPEL & Religious & & 2 & 2 & 10 & 10 \\
\hline 52065 & & $\begin{array}{l}\text { Michaels Military } \\
\text { Housing }\end{array}$ & Office-Medium & & 1 & 1 & 3 & 3 \\
\hline 52065 & & $\begin{array}{l}\text { FAMILY HOUSING } \\
\text { ADMINISTRATION }\end{array}$ & Office-Small & & 0 & 0 & 1 & 1 \\
\hline
\end{tabular}




\begin{tabular}{|c|c|c|c|c|c|c|c|c|}
\hline \multicolumn{4}{|c|}{ Building Info } & \multicolumn{5}{|c|}{ Containers } \\
\hline $\begin{array}{l}\text { Building } \\
\text { No. }\end{array}$ & $\begin{array}{l}\text { Bldg \# } \\
\text { Exten. }\end{array}$ & Organization & $\begin{array}{l}\text { Building } \\
\text { Type }\end{array}$ & $\begin{array}{l}\text { Exterior } \\
\text { Cardboard }\end{array}$ & $\begin{array}{l}\text { Exterior } \\
\text { Paper }\end{array}$ & $\begin{array}{l}\text { Exterior } \\
\text { Drink }\end{array}$ & $\begin{array}{l}\text { Interior } \\
\text { Paper }\end{array}$ & $\begin{array}{l}\text { Interior } \\
\text { Drink }\end{array}$ \\
\hline 52065 & & $\begin{array}{l}\text { DOL FT HUACHUCA } \\
\text { AZ }\end{array}$ & Office-Small & & 0 & 0 & 1 & 1 \\
\hline 52101 & & $\mathrm{HHC} 40 \mathrm{SC} B N$ & BNHQ & 1 & 0 & 0 & 3 & 3 \\
\hline 52101 & & MFLC, $11 \mathrm{SC}$ BDE & BNHQ & & 0 & 0 & 1 & 1 \\
\hline 52101 & & CECOM & BNHQ & & 0 & 0 & 1 & 1 \\
\hline 52104 & & $\begin{array}{l}\text { ARMY EDUCATION } \\
\text { CENTER }\end{array}$ & GIB & 1 & 2 & 2 & 6 & 6 \\
\hline 52107 & & $\begin{array}{l}\text { BDE HHC THEAT } \\
\text { TAC SIG }\end{array}$ & DFAC & 2 & 1 & 1 & 6 & 6 \\
\hline 52110 & & $\begin{array}{l}\text { REAL PROPERTY, } \\
\text { DPW }\end{array}$ & BNHQ & 1 & 1 & 1 & 6 & 6 \\
\hline 52111 & & $\begin{array}{l}\text { CYS SERVICES, } \\
\text { FMWR }\end{array}$ & Office-Small & & 1 & 1 & 3 & 3 \\
\hline 52120 & & $40 \mathrm{SCBN}$ & BNHQ & & 1 & 1 & 5 & 5 \\
\hline 52131 & & UPH HOUSING, DPW & UEPH & & 2 & 2 & 8 & 8 \\
\hline 52132 & & UPH HOUSING, DPW & UEPH & & 1 & 1 & 6 & 6 \\
\hline 52136 & & $\begin{array}{l}\text { Soldier Community } \\
\text { Bldg. }\end{array}$ & Religious & 1 & 1 & 1 & 5 & 5 \\
\hline 52137 & & UPH HOUSING, DPW & UEPH & & 1 & 1 & 6 & 6 \\
\hline 52138 & & UPH HOUSING, DPW & UEPH & & 2 & 2 & 8 & 8 \\
\hline 52141 & & UPH HOUSING, DPW & UEPH & & 1 & 1 & 6 & 6 \\
\hline 52142 & & UPH HOUSING, DPW & UEPH & & 1 & 1 & 6 & 6 \\
\hline 52204 & & Safety Office & Office-Small & & 0 & 0 & 1 & 1 \\
\hline 52204 & & Union & Office-Small & & 0 & 0 & 1 & 1 \\
\hline 52204 & & UPH HOUSING, DPW & $\begin{array}{l}\text { Training } \\
\text { Barracks }\end{array}$ & 1 & 4 & 4 & 18 & 18 \\
\hline 52204 & & $\begin{array}{l}\text { REAL PROPERTY, } \\
\text { DPW }\end{array}$ & $\begin{array}{l}\text { Training } \\
\text { Barracks }\end{array}$ & & 0 & 0 & 1 & 1 \\
\hline 52208 & & $\begin{array}{l}\text { REAL PROPERTY, } \\
\text { DPW }\end{array}$ & Office-Small & & 0 & 0 & 1 & 1 \\
\hline 52220 & & $\begin{array}{l}\text { FAMILY FITNESS } \\
\text { CENTER }\end{array}$ & PFF & & 0 & 0 & 1 & 1 \\
\hline 52307 & & $\begin{array}{l}\text { REAL PROPERTY, } \\
\text { DPW }\end{array}$ & $\mathrm{COF}$ & & 1 & 1 & 4 & 4 \\
\hline 52308 & & $\begin{array}{l}\text { REAL PROPERTY, } \\
\text { DPW }\end{array}$ & BNHQ & & 1 & 1 & 4 & 4 \\
\hline 52308 & & $11 \mathrm{SC} B D E \mathrm{HHC}$ & GPW & & 1 & 1 & 2 & 2 \\
\hline 52308 & & WTU & $\begin{array}{l}\text { Training } \\
\text { Barracks }\end{array}$ & & 1 & 1 & 6 & 6 \\
\hline 52308 & & $11 \mathrm{SC} B D E \mathrm{HHC}$ & UEPH & & 4 & 4 & 22 & 22 \\
\hline 52309 & & CO A 40 SC BN & COF & & 0 & 0 & 2 & 2 \\
\hline 52309 & & HHC $40 \mathrm{SC} B N$ & $\mathrm{COF}$ & & 0 & 0 & 2 & 2 \\
\hline
\end{tabular}




\begin{tabular}{|c|c|c|c|c|c|c|c|c|}
\hline \multicolumn{4}{|c|}{ Building Info } & \multicolumn{5}{|c|}{ Containers } \\
\hline $\begin{array}{l}\text { Building } \\
\text { No. }\end{array}$ & $\begin{array}{l}\text { Bldg \# } \\
\text { Exten. }\end{array}$ & Organization & $\begin{array}{l}\text { Building } \\
\text { Type }\end{array}$ & $\begin{array}{l}\text { Exterior } \\
\text { Cardboard }\end{array}$ & $\begin{array}{l}\text { Exterior } \\
\text { Paper }\end{array}$ & $\begin{array}{l}\text { Exterior } \\
\text { Drink }\end{array}$ & $\begin{array}{l}\text { Interior } \\
\text { Paper }\end{array}$ & $\begin{array}{l}\text { Interior } \\
\text { Drink }\end{array}$ \\
\hline 52309 & & $11 \mathrm{SC} B D E \mathrm{HHC}$ & UEPH & & 6 & 6 & 28 & 28 \\
\hline 52310 & & $\mathrm{COC} 40 \mathrm{SC} B N$ & $\mathrm{COF}$ & & 0 & 0 & 2 & 2 \\
\hline 52310 & & CO B 40 SC BN & $\mathrm{COF}$ & & 0 & 0 & 2 & 2 \\
\hline 52313 & & $\begin{array}{l}\text { BDE HHC THEAT } \\
\text { TAC SIG }\end{array}$ & UEPH & 1 & 1 & 1 & 1 & 1 \\
\hline 53301 & & $\begin{array}{l}\text { TECHNOLOGY } \\
\text { INTERGRATION } \\
\text { CENTER }\end{array}$ & INFOSYS & 1 & 4 & 4 & 19 & 19 \\
\hline 53302 & & $\begin{array}{l}\text { TECHNOLOGY } \\
\text { INTERGRATION } \\
\text { CENTER }\end{array}$ & INFOSYS & & 4 & 4 & 19 & 19 \\
\hline 53310 & & $\begin{array}{l}\text { CMD USA INFO SYS } \\
\text { ENGR }\end{array}$ & GPW & & 0 & 0 & 2 & 2 \\
\hline 53320 & & $\begin{array}{l}\text { BDE HHC THEAT } \\
\text { TAC SIG }\end{array}$ & $\mathrm{COF}$ & 1 & 2 & 2 & 9 & 9 \\
\hline 53321 & & $\begin{array}{l}\text { BDE HHC THEAT } \\
\text { TAC SIG }\end{array}$ & $\mathrm{COF}$ & & 1 & 1 & 6 & 6 \\
\hline 55340 & & $\begin{array}{l}\text { CMD USA INFO SYS } \\
\text { ENGR }\end{array}$ & INFOSYS & & 0 & 0 & 2 & 2 \\
\hline 55350 & & EPG & INFOSYS & 1 & 4 & 4 & 20 & 20 \\
\hline 56301 & & EPG & INFOSYS & 1 & 3 & 3 & 14 & 14 \\
\hline 56307 & & EPG & INFOSYS & & 0 & 0 & 2 & 2 \\
\hline 57305 & A & $\begin{array}{l}\text { DISA JOINT INTEROP } \\
\text { TEST CMD SPT }\end{array}$ & INFOSYS & & 1 & 1 & 5 & 5 \\
\hline 57305 & & $\begin{array}{l}\text { DISA JOINT INTEROP } \\
\text { TEST CMD SPT }\end{array}$ & INFOSYS & 1 & 8 & 8 & 41 & 41 \\
\hline 57428 & A & $\begin{array}{l}\text { DISA JOINT INTEROP } \\
\text { TEST CMD SPT }\end{array}$ & INFOSYS & & 1 & 1 & 3 & 3 \\
\hline 57428 & B & $\begin{array}{l}\text { DISA JOINT INTEROP } \\
\text { TEST CMD SPT }\end{array}$ & INFOSYS & & 1 & 1 & 3 & 3 \\
\hline 57428 & c & $\begin{array}{l}\text { DISA JOINT INTEROP } \\
\text { TEST CMD SPT }\end{array}$ & INFOSYS & & 1 & 1 & 3 & 3 \\
\hline 57428 & D & $\begin{array}{l}\text { DISA JOINT INTEROP } \\
\text { TEST CMD SPT }\end{array}$ & INFOSYS & & 1 & 1 & 3 & 3 \\
\hline 57428 & $\mathrm{E}$ & $\begin{array}{l}\text { DISA JOINT INTEROP } \\
\text { TEST CMD SPT }\end{array}$ & INFOSYS & & 1 & 1 & 3 & 3 \\
\hline 57428 & $\mathrm{~F}$ & $\begin{array}{l}\text { DISA JOINT INTEROP } \\
\text { TEST CMD SPT }\end{array}$ & INFOSYS & & 1 & 1 & 4 & 4 \\
\hline 57428 & & $\begin{array}{l}\text { DISA JOINT INTEROP } \\
\text { TEST CMD SPT }\end{array}$ & INFOSYS & 1 & 2 & 2 & 8 & 8 \\
\hline 57430 & A & $\begin{array}{l}\text { DISA JOINT INTEROP } \\
\text { TEST CMD SPT }\end{array}$ & INFOSYS & 1 & 1 & 1 & 5 & 5 \\
\hline 57430 & B & $\begin{array}{l}\text { DISA JOINT INTEROP } \\
\text { TEST CMD SPT }\end{array}$ & INFOSYS & & 1 & 1 & 5 & 5 \\
\hline
\end{tabular}




\begin{tabular}{|c|c|c|c|c|c|c|c|c|}
\hline \multicolumn{4}{|c|}{ Building Info } & \multicolumn{5}{|c|}{ Containers } \\
\hline $\begin{array}{l}\text { Building } \\
\text { No. }\end{array}$ & $\begin{array}{l}\text { Bldg \# } \\
\text { Exten. }\end{array}$ & Organization & $\begin{array}{l}\text { Building } \\
\text { Type }\end{array}$ & $\begin{array}{l}\text { Exterior } \\
\text { Cardboard }\end{array}$ & $\begin{array}{l}\text { Exterior } \\
\text { Paper }\end{array}$ & $\begin{array}{l}\text { Exterior } \\
\text { Drink }\end{array}$ & $\begin{array}{l}\text { Interior } \\
\text { Paper }\end{array}$ & $\begin{array}{l}\text { Interior } \\
\text { Drink }\end{array}$ \\
\hline 57430 & & $\begin{array}{l}\text { DISA JOINT INTEROP } \\
\text { TEST CMD SPT }\end{array}$ & INFOSYS & & 0 & 0 & 1 & 1 \\
\hline 57431 & & $\begin{array}{l}\text { DISA JOINT INTEROP } \\
\text { TEST CMD SPT }\end{array}$ & INFOSYS & & 0 & 0 & 1 & 1 \\
\hline 57434 & & $\begin{array}{l}\text { DISA JOINT INTEROP } \\
\text { TEST CMD SPT }\end{array}$ & INFOSYS & & 1 & 1 & 3 & 3 \\
\hline 57435 & & $\begin{array}{l}\text { DISA JOINT INTEROP } \\
\text { TEST CMD SPT }\end{array}$ & INFOSYS & & 0 & 0 & 1 & 1 \\
\hline 57437 & & $\begin{array}{l}\text { DISA JOINT INTEROP } \\
\text { TEST CMD SPT }\end{array}$ & GPW & & 0 & 0 & 1 & 1 \\
\hline 57439 & $A$ & $\begin{array}{l}\text { DISA JOINT INTEROP } \\
\text { TEST CMD SPT }\end{array}$ & INFOSYS & & 0 & 0 & 2 & 2 \\
\hline 57439 & B & $\begin{array}{l}\text { DISA JOINT INTEROP } \\
\text { TEST CMD SPT }\end{array}$ & INFOSYS & & 1 & 1 & 4 & 4 \\
\hline 57439 & & $\begin{array}{l}\text { DISA JOINT INTEROP } \\
\text { TEST CMD SPT }\end{array}$ & TEMF & & 0 & 0 & 1 & 1 \\
\hline 61610 & & $\begin{array}{l}\text { FT HUACHUCA } \\
\text { DEFENSE } \\
\text { COMMISSARY } \\
\text { AGENCY }\end{array}$ & $\begin{array}{l}\text { Retail- } \\
\text { Supermarket }\end{array}$ & 4 & 7 & 7 & 36 & 36 \\
\hline 61701 & & $\begin{array}{l}\text { FT HUACHUCA } \\
\text { FMWRF }\end{array}$ & PFF & & 2 & 2 & 10 & 10 \\
\hline 61730 & & $\begin{array}{l}\text { W1E8AA CTR USA } \\
\text { INT CEN \& FT- } \\
04289\end{array}$ & GIB & & 1 & 1 & 4 & 4 \\
\hline 61730 & & $\begin{array}{l}\text { W1E8AA CTR USA } \\
\text { INT CEN \& FT- } \\
04289\end{array}$ & Office-Large & 1 & 5 & 5 & 27 & 27 \\
\hline 61730 & & $\begin{array}{l}\text { TRADOC Culture } \\
\text { Center }\end{array}$ & Office-Small & & 0 & 0 & 2 & 2 \\
\hline 61801 & & $\begin{array}{l}\text { WODA83 AMC/ASC } \\
\text { LOGISTICS } \\
\text { SUPPORT TEAM } \\
\text { OVERHIRES }\end{array}$ & BNHQ & & 0 & 0 & 1 & 1 \\
\hline 61801 & & $\begin{array}{l}\text { DIS DISTRIBUTED } \\
\text { LEARNING SYSTEM }\end{array}$ & GIB & & 0 & 0 & 2 & 2 \\
\hline 61801 & & $\begin{array}{l}\text { ACT USA SIGNAL } \\
\text { NETWOR }\end{array}$ & GIB & & 0 & 0 & 2 & 2 \\
\hline 61801 & & $\begin{array}{l}\text { CTR USA CIV PERS } \\
\text { OPS }\end{array}$ & GIB & & 0 & 0 & 1 & 1 \\
\hline 61801 & & $\begin{array}{l}\text { CTR USA CIV PERS } \\
\text { OPS }\end{array}$ & GIB & & 0 & 0 & 1 & 1 \\
\hline 61801 & & $\begin{array}{l}\text { Communications } \\
\text { Security Logistics } \\
\text { Activity (CSLA) }\end{array}$ & GIB & & 0 & 0 & 1 & 1 \\
\hline 61801 & & CECOM & GIB & & 0 & 0 & 1 & 1 \\
\hline
\end{tabular}




\begin{tabular}{|c|c|c|c|c|c|c|c|c|}
\hline \multicolumn{4}{|c|}{ Building Info } & \multicolumn{5}{|c|}{ Containers } \\
\hline $\begin{array}{l}\text { Building } \\
\text { No. }\end{array}$ & $\begin{array}{l}\text { Bldg \# } \\
\text { Exten. }\end{array}$ & Organization & $\begin{array}{l}\text { Building } \\
\text { Type }\end{array}$ & $\begin{array}{l}\text { Exterior } \\
\text { Cardboard }\end{array}$ & $\begin{array}{l}\text { Exterior } \\
\text { Paper }\end{array}$ & $\begin{array}{l}\text { Exterior } \\
\text { Drink }\end{array}$ & $\begin{array}{l}\text { Interior } \\
\text { Paper }\end{array}$ & $\begin{array}{l}\text { Interior } \\
\text { Drink }\end{array}$ \\
\hline 61801 & & NETCOM & GPW & & 1 & 1 & 4 & 4 \\
\hline 61801 & & C-TNOSC & INFOSYS & & 3 & 3 & 14 & 14 \\
\hline 61801 & & $\begin{array}{l}\text { ACT USA SIGNAL } \\
\text { NETWOR }\end{array}$ & INFOSYS & & 1 & 1 & 7 & 7 \\
\hline 61801 & & $\begin{array}{l}\text { CMD USA INFO SYS } \\
\text { ENGR }\end{array}$ & INFOSYS & & 1 & 1 & 6 & 6 \\
\hline 61801 & & $\begin{array}{l}\text { DPTMS, USAG FT } \\
\text { HUACHUCA }\end{array}$ & INFOSYS & & 0 & 0 & 2 & 2 \\
\hline 61801 & & NETCOM & INFOSYS & & 0 & 0 & 1 & 1 \\
\hline 61801 & & NETCOM & Office-Large & 1 & 15 & 15 & 76 & 76 \\
\hline 61801 & & $\begin{array}{l}\text { Communications } \\
\text { Security Logistics } \\
\text { Activity (CSLA) }\end{array}$ & Office-Medium & & 3 & 3 & 17 & 17 \\
\hline 61801 & & $\begin{array}{l}\text { ACT USA SIGNAL } \\
\text { NETWOR }\end{array}$ & Office-Medium & & 2 & 2 & 12 & 12 \\
\hline 61801 & & $\begin{array}{l}\text { CTR USA CIV PERS } \\
\text { OPS }\end{array}$ & Office-Medium & & 2 & 2 & 11 & 11 \\
\hline 61801 & & C-TNOSC & Office-Medium & & 2 & 2 & 11 & 11 \\
\hline 61801 & & $\begin{array}{l}\text { CMD USA INFO SYS } \\
\text { ENGR }\end{array}$ & Office-Medium & & 1 & 1 & 7 & 7 \\
\hline 61801 & & ACC & Office-Medium & & 1 & 1 & 6 & 6 \\
\hline 61801 & & CECOM & Office-Medium & & 1 & 1 & 5 & 5 \\
\hline 61801 & & ISEC & Office-Medium & & 1 & 1 & 5 & 5 \\
\hline 61801 & & ACCAPG & Office-Small & & 1 & 1 & 3 & 3 \\
\hline 61801 & & $\begin{array}{l}\text { W6UX RCERT } 1 \\
\text { (CONUS) }\end{array}$ & Office-Small & & 1 & 1 & 3 & 3 \\
\hline 61801 & & $\begin{array}{l}\text { REAL PROPERTY, } \\
\text { DPW }\end{array}$ & Office-Small & & 1 & 1 & 3 & 3 \\
\hline 61801 & & $\begin{array}{l}\text { CTR USA INT CEN \& } \\
\text { FT }\end{array}$ & Office-Small & & 0 & 0 & 1 & 1 \\
\hline 61801 & & $\begin{array}{l}\text { OPM INVESTIGATIVE } \\
\text { SVC }\end{array}$ & Office-Small & & 0 & 0 & 1 & 1 \\
\hline 61801 & & CCIU TEAM C & Office-Small & & 0 & 0 & 1 & 1 \\
\hline 61801 & & C-TNOSC & $\mathrm{OHC}$ & & 1 & 1 & 3 & 3 \\
\hline 61801 & & AAFES & PX & 2 & 1 & 1 & 2 & 2 \\
\hline 61801 & & NETCOM & Religious & & 1 & 1 & 4 & 4 \\
\hline 61801 & & SJA USAISC & Religious & & 0 & 0 & 1 & 1 \\
\hline 61809 & & CO B 305 Ml BN & GIB & 1 & 11 & 11 & 55 & 55 \\
\hline 61820 & & $305 \mathrm{Ml} \mathrm{BN}$ & GIB & & 4 & 4 & 20 & 20 \\
\hline 62702 & & CO C 304 MI BN & GIB & 1 & 3 & 3 & 16 & 16 \\
\hline 62703 & & CO B 305 Ml BN & GIB & & 1 & 1 & 3 & 3 \\
\hline 62703 & & $\mathrm{CO}$ A $305 \mathrm{Ml} B N$ & GIB & & 0 & 0 & 2 & 2 \\
\hline
\end{tabular}




\begin{tabular}{|c|c|c|c|c|c|c|c|c|}
\hline \multicolumn{4}{|c|}{ Building Info } & \multicolumn{5}{|c|}{ Containers } \\
\hline $\begin{array}{l}\text { Building } \\
\text { No. }\end{array}$ & $\begin{array}{l}\text { Bldg \# } \\
\text { Exten. }\end{array}$ & Organization & $\begin{array}{l}\text { Building } \\
\text { Type }\end{array}$ & $\begin{array}{l}\text { Exterior } \\
\text { Cardboard }\end{array}$ & $\begin{array}{l}\text { Exterior } \\
\text { Paper }\end{array}$ & $\begin{array}{l}\text { Exterior } \\
\text { Drink }\end{array}$ & $\begin{array}{l}\text { Interior } \\
\text { Paper }\end{array}$ & $\begin{array}{l}\text { Interio } \\
\text { Drink }\end{array}$ \\
\hline 62703 & & $\begin{array}{l}\text { CTR USA INT CEN \& } \\
\text { FT }\end{array}$ & GIB & & 0 & 0 & 1 & 1 \\
\hline 62704 & & $\begin{array}{l}\text { CTR USA INT CEN \& } \\
\text { FT }\end{array}$ & GIB & 1 & 2 & 2 & 8 & 8 \\
\hline 62711 & & $\begin{array}{l}\text { CTR USA INT CEN \& } \\
\text { FT }\end{array}$ & Office-Medium & & 2 & 2 & 9 & 9 \\
\hline 62712 & & CISAC & GIB & & 2 & 2 & 9 & 9 \\
\hline 62715 & & CO A 309 MI BN & GIB & & 1 & 1 & 3 & 3 \\
\hline 62718 & & NCO ACADEMY & BDEHQ & 1 & 0 & 0 & 1 & 1 \\
\hline 62718 & & NCO ACADEMY & $\begin{array}{l}\text { Training } \\
\text { Barracks }\end{array}$ & & 6 & 6 & 31 & 31 \\
\hline 62722 & & NCO ACADEMY & GIB & 1 & 3 & 3 & 13 & 13 \\
\hline 62723 & & $\begin{array}{l}\text { TRAINING } \\
\text { MATERIALS } \\
\text { SUPPORT BRANCH }\end{array}$ & GPW & & 0 & 0 & 2 & 2 \\
\hline 62723 & & $\begin{array}{l}\text { MILITARY } \\
\text { INTELLIGENCE } \\
\text { LIBRARY }\end{array}$ & Office-Medium & & 1 & 1 & 3 & 3 \\
\hline 62750 & & CECOM & INFOSYS & 1 & 1 & 1 & 7 & 7 \\
\hline 63845 & & $\begin{array}{l}\text { CTR USA INT CEN \& } \\
\text { FT }\end{array}$ & GIB & 1 & 5 & 5 & 27 & 27 \\
\hline 63845 & & $\begin{array}{l}\text { CTR USA INT CEN \& } \\
\text { FT }\end{array}$ & INFOSYS & & 0 & 0 & 1 & 1 \\
\hline 63902 & & CO A 305 MI BN & GIB & 2 & 5 & 5 & 23 & 23 \\
\hline 63902 & & 304TH MI BN & GIB & & 3 & 3 & 16 & 16 \\
\hline 63902 & & NCO ACADEMY & GIB & & 3 & 3 & 13 & 13 \\
\hline 63902 & & $\begin{array}{l}\text { CO E, HUMINT } \\
\text { CMTE, CI DIVISION }\end{array}$ & GIB & & 0 & 0 & 1 & 1 \\
\hline 63902 & & USAICS COE & Office-Large & & 3 & 3 & 17 & 17 \\
\hline 67601 & & Cochise College & & 2 & 3 & 3 & 15 & 15 \\
\hline 70525 & & $\begin{array}{l}\text { THUNDER } \\
\text { MOUNTAIN ACTIVITY } \\
\text { CENTER }\end{array}$ & DFAC & 2 & 2 & 2 & 12 & 12 \\
\hline 72805 & & $\begin{array}{l}\text { BN EXPEDITIONARY } \\
\text { SIG }\end{array}$ & TEMF & 1 & 1 & 1 & 5 & 5 \\
\hline 75801 & & $40 \mathrm{SC} \mathrm{BN}$ & TEMF & 1 & 1 & 1 & 2 & 2 \\
\hline 75805 & & $40 \mathrm{SC} B N$ & TEMF & & 0 & 0 & 2 & 2 \\
\hline 75807 & & $40 \mathrm{SC} B N$ & GPW & & 0 & 0 & 1 & 1 \\
\hline 75901 & & $\begin{array}{l}\text { DOL FT HUACHUCA } \\
\text { AZ }\end{array}$ & TEMF & & 0 & 0 & 3 & 3 \\
\hline 75902 & & $\begin{array}{l}\text { DOL FT HUACHUCA } \\
\text { AZ }\end{array}$ & TEMF & 1 & 1 & 1 & 2 & 2 \\
\hline
\end{tabular}




\begin{tabular}{|c|c|c|c|c|c|c|c|c|}
\hline \multicolumn{4}{|c|}{ Building Info } & \multicolumn{5}{|c|}{ Containers } \\
\hline $\begin{array}{l}\text { Building } \\
\text { No. }\end{array}$ & $\begin{array}{l}\text { Bldg \# } \\
\text { Exten. }\end{array}$ & Organization & $\begin{array}{l}\text { Building } \\
\text { Type }\end{array}$ & $\begin{array}{l}\text { Exterior } \\
\text { Cardboard }\end{array}$ & $\begin{array}{l}\text { Exterior } \\
\text { Paper }\end{array}$ & $\begin{array}{l}\text { Exterior } \\
\text { Drink }\end{array}$ & $\begin{array}{l}\text { Interior } \\
\text { Paper }\end{array}$ & $\begin{array}{l}\text { Interior } \\
\text { Drink }\end{array}$ \\
\hline 75903 & & $\begin{array}{l}\text { DOL FT HUACHUCA } \\
\text { AZ }\end{array}$ & TEMF & & 0 & 0 & 2 & 2 \\
\hline 80011 & & $\begin{array}{l}\text { CMD GLOBAL } \\
\text { NETWORK EN }\end{array}$ & $\mathrm{GIB}$ & & 0 & 0 & 1 & 1 \\
\hline 80011 & & CO D 306 MI BN & INFOSYS & 1 & 1 & 1 & 4 & 4 \\
\hline 80012 & & $\begin{array}{l}\text { REAL PROPERTY, } \\
\text { DPW }\end{array}$ & Religious & & 0 & 0 & 1 & 1 \\
\hline 80022 & A & $\begin{array}{l}\text { CO E, HUMINT } \\
\text { CMTE, CI DIVISION }\end{array}$ & GIB & & 2 & 2 & 10 & 10 \\
\hline 80023 & A & $\begin{array}{l}\text { CO E, HUMINT } \\
\text { CMTE, CI DIVISION }\end{array}$ & GIB & & 1 & 1 & 3 & 3 \\
\hline 80122 & & CO D 306 MI BN & GIB & 2 & 5 & 5 & 25 & 25 \\
\hline 80305 & & $\begin{array}{l}\text { CO A 2-13 AVN } \\
\text { REGT }\end{array}$ & $\mathrm{COF}$ & & 0 & 0 & 2 & 2 \\
\hline 80305 & & $\begin{array}{l}\text { CO A 2-13 AVN } \\
\text { REGT }\end{array}$ & UEPH & 2 & 4 & 4 & 21 & 21 \\
\hline 80306 & & COE $305 \mathrm{Ml} \mathrm{BN}$ & $\mathrm{COF}$ & & 0 & 0 & 1 & 1 \\
\hline 80306 & & CO D 305 MI BN & UEPH & & 4 & 4 & 21 & 21 \\
\hline 80405 & & $\begin{array}{l}\text { DPW, USAG FT } \\
\text { HUACHUCA }\end{array}$ & Office-Small & & 0 & 0 & 1 & 1 \\
\hline 80405 & & CO A 213th & $\begin{array}{l}\text { Training } \\
\text { Barracks }\end{array}$ & 1 & 3 & 3 & 14 & 14 \\
\hline 80405 & & $\begin{array}{l}\text { Marines } \\
\text { Detachment }\end{array}$ & $\begin{array}{l}\text { Training } \\
\text { Barracks }\end{array}$ & & 2 & 2 & 8 & 8 \\
\hline 80406 & & CO D 305 MI BN & $\begin{array}{l}\text { Training } \\
\text { Barracks }\end{array}$ & 1 & 4 & 4 & 18 & 18 \\
\hline 80406 & & UPB Branch & $\begin{array}{l}\text { Training } \\
\text { Barracks }\end{array}$ & & 1 & 1 & 5 & 5 \\
\hline 80501 & & $\begin{array}{l}\text { MILITARY CLOTHING } \\
\text { STORE }\end{array}$ & PX & 2 & 0 & 0 & 2 & 2 \\
\hline 80503 & & $\begin{array}{l}\text { REAL PROPERTY, } \\
\text { DPW }\end{array}$ & DFAC & 2 & 1 & 1 & 6 & 6 \\
\hline 80504 & & $\begin{array}{l}\text { REAL PROPERTY, } \\
\text { DPW }\end{array}$ & DFAC & 2 & 1 & 1 & 6 & 6 \\
\hline 80505 & & CO A $304 \mathrm{Ml} \mathrm{BN}$ & GIB & & 6 & 6 & 28 & 28 \\
\hline 80505 & & CO B 304 MI BN & GIB & & 2 & 2 & 5 & 5 \\
\hline 80706 & & $\begin{array}{l}\text { USA OPTEC TEXCOM } \\
\text { IEWT DIR }\end{array}$ & INFOSYS & 1 & 3 & 3 & 14 & 14 \\
\hline 81305 & & CO B $305 \mathrm{Ml} \mathrm{BN}$ & $\begin{array}{l}\text { Training } \\
\text { Barracks }\end{array}$ & 1 & 3 & 3 & 17 & 17 \\
\hline 81305 & & CO A $305 \mathrm{Ml} \mathrm{BN}$ & $\begin{array}{l}\text { Training } \\
\text { Barracks }\end{array}$ & & 2 & 2 & 9 & 9 \\
\hline 81401 & & $305 \mathrm{Ml} \mathrm{BN}$ & BNHQ & & 0 & 0 & 3 & 3 \\
\hline
\end{tabular}




\begin{tabular}{|c|c|c|c|c|c|c|c|c|}
\hline \multicolumn{4}{|c|}{ Building Info } & \multicolumn{5}{|c|}{ Containers } \\
\hline $\begin{array}{l}\text { Building } \\
\text { No. }\end{array}$ & $\begin{array}{l}\text { Bldg \# } \\
\text { Exten. }\end{array}$ & Organization & $\begin{array}{l}\text { Building } \\
\text { Type }\end{array}$ & $\begin{array}{l}\text { Exterior } \\
\text { Cardboard }\end{array}$ & $\begin{array}{l}\text { Exterior } \\
\text { Paper }\end{array}$ & $\begin{array}{l}\text { Exterior } \\
\text { Drink }\end{array}$ & $\begin{array}{l}\text { Interior } \\
\text { Paper }\end{array}$ & $\begin{array}{l}\text { Interior } \\
\text { Drink }\end{array}$ \\
\hline 81405 & & CO B 305 MI BN & $\begin{array}{l}\text { Training } \\
\text { Barracks }\end{array}$ & 1 & 2 & 2 & 9 & 9 \\
\hline 81405 & & $\begin{array}{l}316 \text { TRNG SQD, } \\
\text { USAF }\end{array}$ & $\begin{array}{l}\text { Training } \\
\text { Barracks }\end{array}$ & & 1 & 1 & 6 & 6 \\
\hline 81501 & & USAG & $\mathrm{OHC}$ & & 0 & 0 & 1 & 1 \\
\hline 81502 & & 111TH MI BDE & BDEHQ & 1 & 1 & 1 & 1 & 1 \\
\hline 82012 & & $\begin{array}{l}\text { TRAINING } \\
\text { MATERIALS } \\
\text { SUPPORT BRANCH }\end{array}$ & Office-Small & & 2 & 2 & 9 & 9 \\
\hline 82013 & & $\begin{array}{l}\text { TRAINING } \\
\text { MATERIALS } \\
\text { SUPPORT BRANCH }\end{array}$ & INFOSYS & & 0 & 0 & 1 & 1 \\
\hline 82502 & & MAINT FMX FHFO & TEMF & 1 & 1 & 1 & 5 & 5 \\
\hline 82812 & & EPG & INFOSYS & 1 & 1 & 1 & 5 & 5 \\
\hline 84402 & & CO B 309 MI BN & $\begin{array}{l}\text { Training } \\
\text { Barracks }\end{array}$ & 1 & 8 & 8 & 39 & 39 \\
\hline 84410 & & $\begin{array}{l}\text { DPW, USAG FT } \\
\text { HUACHUCA }\end{array}$ & Religious & & 0 & 0 & 1 & 1 \\
\hline 85202 & & AIT Complex & DFAC & 2 & 3 & 3 & 13 & 13 \\
\hline 85302 & & $\begin{array}{l}\text { 09L CO } 309 \mathrm{Ml} \mathrm{BN} \\
\text { PP }\end{array}$ & BNHQ & & 1 & 1 & 5 & 5 \\
\hline 86302 & & CO A $309 \mathrm{MI} B N$ & $\begin{array}{l}\text { Training } \\
\text { Barracks }\end{array}$ & 1 & 8 & 8 & 39 & 39 \\
\hline 86310 & & $\begin{array}{l}\text { DPW, USAG FT } \\
\text { HUACHUCA }\end{array}$ & Religious & & 0 & 0 & 1 & 1 \\
\hline 86332 & & CO F 309 MI BN & $\begin{array}{l}\text { Training } \\
\text { Barracks }\end{array}$ & 1 & 8 & 8 & 39 & 39 \\
\hline 91110 & & COE $305 \mathrm{MI} \mathrm{BN}$ & TEMF & & 1 & 1 & 7 & 7 \\
\hline 91110 & & $\begin{array}{l}\text { AIR TRAFFIC } \\
\text { CONTROL }\end{array}$ & TEMF & & 0 & 0 & 1 & 1 \\
\hline 91111 & & $\begin{array}{l}\text { AIR TRAFFIC } \\
\text { CONTROL }\end{array}$ & GPW & & 0 & 0 & 1 & 1 \\
\hline 91112 & & 2-13 AVN REGT & BNHQ & 1 & 1 & 1 & 2 & 2 \\
\hline 91112 & & 2-13 AVN REGT & PFF & & 0 & 0 & 1 & 1 \\
\hline 91114 & & 2-13 AVN REGT & TEMF & & 1 & 1 & 6 & 6 \\
\hline 91114 & & 160 SC BDE DUIC & TEMF & & 0 & 0 & 1 & 1 \\
\hline 91122 & & 2-13 AVN REGT & GIB & 1 & 3 & 3 & 14 & 14 \\
\hline 91225 & & 2-13TH AVN BN & GPW & & 0 & 0 & 1 & 1 \\
\hline 91251 & & $\begin{array}{l}\text { DPTMS, USAG FT } \\
\text { HUACHUCA }\end{array}$ & ARC & 1 & 1 & 1 & 2 & 2 \\
\hline 91253 & & FIRE STATION \#3 & TEMF & & 0 & 0 & 1 & 1 \\
\hline 91277 & & $\begin{array}{l}\text { DOL FT HUACHUCA } \\
\text { AZ }\end{array}$ & GPW & & 0 & 0 & 1 & 1 \\
\hline
\end{tabular}




\section{ROI Scenario \#1A}

The groupings of spreadsheets in Table A2 represent the ROI and supporting calculations for Scenario \#1A.

Table A2. ROI Scenario \#1A (ERDC-CERL).

\begin{tabular}{|l|}
\hline \\
PAYBACK PERIOD
\end{tabular}

\begin{tabular}{|lrrr|}
\hline & \$Current Practice & \$ New option & $\begin{array}{c}\text { Net Annual } \\
\text { savings }\end{array}$ \\
\cline { 2 - 4 } One-time cost & N/A & $\$ 421,851$ & \\
Annual cost & N/A & $\$(51,797)$ & $\$ 51,797$ \\
\hline
\end{tabular}

\begin{tabular}{|c|c|c|c|c|}
\hline Item & $\begin{array}{l}\text { \$ Current } \\
\text { Practice }\end{array}$ & $\begin{array}{l}\text { \$ Proposed } \\
\text { Project }\end{array}$ & $\begin{array}{l}\text { \$ Net annual } \\
\text { project cost, by } \\
\text { line item }\end{array}$ & $\begin{array}{l}\text { \$ Net annual } \\
\text { project savings, } \\
\text { by line item }\end{array}$ \\
\hline \multicolumn{5}{|l|}{ One-time costs for new option } \\
\hline $\begin{array}{r}\text { Capital purchase, recycling containers, } \\
\text { whole installation }\end{array}$ & & $\$ 269,791$ & & \\
\hline Labor to set out containers ( 2 months) & & $\$ 19,200$ & & \\
\hline Connection to utilities, site & & $\$-$ & & \\
\hline $\begin{array}{r}\text { Staff time for coordination, contracting, } \\
\text { etc. (1 month) }\end{array}$ & & $\$ 14,400$ & & \\
\hline Outreach to installation, materials & & $\$ 20,000$ & & \\
\hline Labels for bins @ \$20 ea. & & $\$ 98,460$ & & \\
\hline \multicolumn{5}{|l|}{ Annualized costs } \\
\hline \multicolumn{5}{|l|}{ Labor } \\
\hline DPW staff labor (3 months) & N/A & $\$ 43,200$ & $\$ 43,200$ & N/A \\
\hline O\&M labor, gov't & N/A & $\mathrm{N} / \mathrm{A}$ & $\mathrm{N} / \mathrm{A}$ & N/A \\
\hline Service calls & $\mathrm{N} / \mathrm{A}$ & $\mathrm{N} / \mathrm{A}$ & $\mathrm{N} / \mathrm{A}$ & N/A \\
\hline Contractor labor & $\mathrm{N} / \mathrm{A}$ & $\mathrm{N} / \mathrm{A}$ & $\mathrm{N} / \mathrm{A}$ & N/A \\
\hline Periodic training, outreach (2 months) & $\mathrm{N} / \mathrm{A}$ & $\$ 19,200$ & $\$ 19,200$ & N/A \\
\hline \multicolumn{5}{|l|}{ Parts } \\
\hline Consumables & $\mathrm{N} / \mathrm{A}$ & $\mathrm{N} / \mathrm{A}$ & $\mathrm{N} / \mathrm{A}$ & N/A \\
\hline Parts & $\mathrm{N} / \mathrm{A}$ & $\mathrm{N} / \mathrm{A}$ & $\mathrm{N} / \mathrm{A}$ & N/A \\
\hline
\end{tabular}




\begin{tabular}{|c|c|c|c|c|}
\hline Item & $\begin{array}{l}\text { \$ Current } \\
\text { Practice }\end{array}$ & $\begin{array}{l}\text { \$ Proposed } \\
\text { Project }\end{array}$ & $\begin{array}{l}\text { \$ Net annual } \\
\text { project cost, by } \\
\text { line item }\end{array}$ & $\begin{array}{l}\text { \$ Net annual } \\
\text { project savings, } \\
\text { by line item }\end{array}$ \\
\hline \multicolumn{5}{|l|}{ Utilities } \\
\hline Electricity & $\mathrm{N} / \mathrm{A}$ & $\mathrm{N} / \mathrm{A}$ & N/A & N/A \\
\hline Natural gas & $\mathrm{N} / \mathrm{A}$ & $\mathrm{N} / \mathrm{A}$ & N/A & N/A \\
\hline Potable water & $\mathrm{N} / \mathrm{A}$ & $\mathrm{N} / \mathrm{A}$ & N/A & N/A \\
\hline Sanitary sewer & $\mathrm{N} / \mathrm{A}$ & $\mathrm{N} / \mathrm{A}$ & N/A & N/A \\
\hline Liquid fuels & $\mathrm{N} / \mathrm{A}$ & $\mathrm{N} / \mathrm{A}$ & N/A & N/A \\
\hline \multicolumn{5}{|l|}{ Waste } \\
\hline $\begin{array}{r}\text { Avoided tipping fees ( } 1464 \text { tons @ } \\
\$ 35 / \text { ton) } * 70 \% \text { recovery rate }\end{array}$ & $\mathrm{N} / \mathrm{A}$ & $\$(35,868)$ & N/A & $\$ 35,868$ \\
\hline $\begin{array}{r}\text { Additional cost for hauling recyclables } \\
(1464 \text { tons @ } \$ 90.42 / \text { ton }) * 70 \% \text { recovery } \\
\text { rate }\end{array}$ & $\mathrm{N} / \mathrm{A}$ & $\$ 92,662$ & $\$ 92,662$ & N/A \\
\hline Hazardous waste handling and disposal & $\mathrm{N} / \mathrm{A}$ & $\mathrm{N} / \mathrm{A}$ & N/A & N/A \\
\hline \multicolumn{5}{|l|}{ Environmental Compliance } \\
\hline Staff time for permitting & $\mathrm{N} / \mathrm{A}$ & $\mathrm{N} / \mathrm{A}$ & N/A & N/A \\
\hline Fees & $\mathrm{N} / \mathrm{A}$ & $\mathrm{N} / \mathrm{A}$ & N/A & N/A \\
\hline \multicolumn{5}{|l|}{ Vehicle Use (cost to gov't) } \\
\hline Fuel cost & $\mathrm{N} / \mathrm{A}$ & $\mathrm{N} / \mathrm{A}$ & $\mathrm{N} / \mathrm{A}$ & N/A \\
\hline Security & $\mathrm{N} / \mathrm{A}$ & $\mathrm{N} / \mathrm{A}$ & $\mathrm{N} / \mathrm{A}$ & N/A \\
\hline Pavement maintenance & $\mathrm{N} / \mathrm{A}$ & $\mathrm{N} / \mathrm{A}$ & N/A & N/A \\
\hline \multicolumn{5}{|l|}{ Other } \\
\hline Market value of recyclables ( $70 \%$ recovery) & $\mathrm{N} / \mathrm{A}$ & $\$(170,991)$ & $\mathrm{N} / \mathrm{A}$ & $\$ 170,991$ \\
\hline Misc. 2 & $\mathrm{~N} / \mathrm{A}$ & $\mathrm{N} / \mathrm{A}$ & N/A & N/A \\
\hline Misc. 3 & $\mathrm{~N} / \mathrm{A}$ & $\mathrm{N} / \mathrm{A}$ & $\mathrm{N} / \mathrm{A}$ & N/A \\
\hline Misc. 4 & $\mathrm{~N} / \mathrm{A}$ & $\mathrm{N} / \mathrm{A}$ & $\mathrm{N} / \mathrm{A}$ & N/A \\
\hline Misc. 5 & $\mathrm{~N} / \mathrm{A}$ & $\mathrm{N} / \mathrm{A}$ & $\mathrm{N} / \mathrm{A}$ & N/A \\
\hline TOTAL Project Implementation Cost & & $\$ 421,851$ & & \\
\hline Total Annual Cost \& Savings & $\$-$ & $\$(51,797)$ & $\$ 155,062$ & $\$ 206,859$ \\
\hline
\end{tabular}




\section{ROI Scenario \#1B}

The groupings of spreadsheets in Table A3 represent the ROI and supporting calculations for Scenario \#1B.

Table A3. ROI Scenario \#1B (ERDC-CERL).

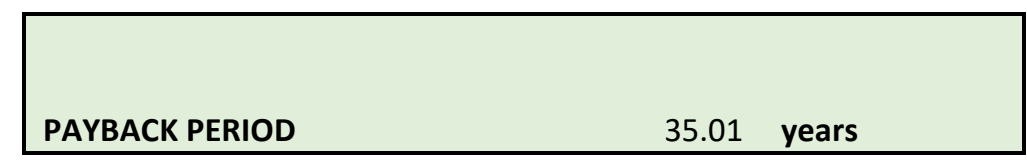

\begin{tabular}{|l|rrr|}
\hline & \$Current Practice & \$ New option & $\begin{array}{c}\text { Net Annual } \\
\text { savings }\end{array}$ \\
\hline One-time cost & & $\$ 571,851$ & \\
Annual cost & N/A & $\$(16,334)$ & $\$ 16,334$ \\
\hline
\end{tabular}

\begin{tabular}{|c|c|c|c|c|}
\hline Item & $\begin{array}{l}\text { \$ Current } \\
\text { Practice }\end{array}$ & $\begin{array}{l}\text { \$ Proposed } \\
\text { Project }\end{array}$ & $\begin{array}{l}\text { \$ Net Annual } \\
\text { Project Cost, by } \\
\text { Line Item }\end{array}$ & $\begin{array}{l}\text { \$ Net Annual } \\
\text { Project Savings, } \\
\text { by Line Item }\end{array}$ \\
\hline \multicolumn{5}{|l|}{ One-time costs for new option } \\
\hline $\begin{array}{r}\text { Capital purchase, recycling containers, } \\
\text { whole installation }+2 \text { balers }+1 \text { forklift }+ \\
\text { recycling collection truck }\end{array}$ & & $\$ 389,791$ & & \\
\hline Labor to set out containers ( 2 months) & & $\$ 19,200$ & & \\
\hline Connection to utilities, site & & $\$ 30,000$ & & \\
\hline $\begin{array}{r}\text { Staff time for coordination, contracting, } \\
\text { etc. (one month) }\end{array}$ & & $\$ 14,400$ & & \\
\hline Outreach to installation, materials & & $\$ 20,000$ & & \\
\hline Labels for bins @ \$20 ea. & & $\$ 98,460$ & & \\
\hline \multicolumn{5}{|l|}{ Annualized costs } \\
\hline \multicolumn{5}{|l|}{ Labor } \\
\hline DPW Staff labor (three months) & $\mathrm{N} / \mathrm{A}$ & $\$ 43,200$ & $\$ 43,200$ & $\mathrm{~N} / \mathrm{A}$ \\
\hline $\begin{array}{r}\text { O\&M Labor, Gov't, } 3 \text { people, full time @ } \\
\$ 20 / \text { hr. (NAF?) }\end{array}$ & $\mathrm{N} / \mathrm{A}$ & $\$ 120,000$ & $\$ 120,000$ & $\mathrm{~N} / \mathrm{A}$ \\
\hline Service calls & $\mathrm{N} / \mathrm{A}$ & N/A & $\mathrm{N} / \mathrm{A}$ & $\mathrm{N} / \mathrm{A}$ \\
\hline Contractor labor & $\mathrm{N} / \mathrm{A}$ & $\mathrm{N} / \mathrm{A}$ & $\mathrm{N} / \mathrm{A}$ & $\mathrm{N} / \mathrm{A}$ \\
\hline Periodic training, outreach ( 2 months) & $\mathrm{N} / \mathrm{A}$ & $\$ 19,200$ & $\$ 19,200$ & $\mathrm{~N} / \mathrm{A}$ \\
\hline
\end{tabular}




\begin{tabular}{|c|c|c|c|c|}
\hline Item & $\begin{array}{l}\text { \$Current } \\
\text { Practice }\end{array}$ & $\begin{array}{l}\text { \$ Proposed } \\
\text { Project }\end{array}$ & $\begin{array}{l}\text { \$ Net Annual } \\
\text { Project Cost, by } \\
\text { Line Item } \\
\end{array}$ & $\begin{array}{l}\text { \$ Net Annual } \\
\text { Project Savings, } \\
\text { by Line Item } \\
\end{array}$ \\
\hline \multicolumn{5}{|l|}{ Parts } \\
\hline Consumables & $\mathrm{N} / \mathrm{A}$ & N/A & N/A & N/A \\
\hline Parts & $\mathrm{N} / \mathrm{A}$ & $\mathrm{N} / \mathrm{A}$ & $\mathrm{N} / \mathrm{A}$ & N/A \\
\hline \multicolumn{5}{|l|}{ Utilities } \\
\hline Electricity & $\mathrm{N} / \mathrm{A}$ & $\mathrm{N} / \mathrm{A}$ & N/A & N/A \\
\hline Natural gas & $\mathrm{N} / \mathrm{A}$ & $\mathrm{N} / \mathrm{A}$ & N/A & N/A \\
\hline Potable water & $\mathrm{N} / \mathrm{A}$ & $\mathrm{N} / \mathrm{A}$ & N/A & N/A \\
\hline Sanitary sewer & $\mathrm{N} / \mathrm{A}$ & & N/A & N/A \\
\hline Liquid fuels & N/A & $\$ 8,125$ & $\$ 8,125$ & N/A \\
\hline \multicolumn{5}{|l|}{ Waste } \\
\hline $\begin{array}{r}\text { Avoided tipping fees (1464 tons @ } \\
\$ 35 / \text { ton) * 70\% recovery rate }\end{array}$ & $\mathrm{N} / \mathrm{A}$ & $\$(35,868)$ & $\mathrm{N} / \mathrm{A}$ & $\$ 35,868$ \\
\hline $\begin{array}{r}\text { Additional cost for hauling recyclables } \\
(1464 \text { tons @ } \$ 90.42 / \text { ton }) * 70 \% \text { recovery } \\
\text { rate }\end{array}$ & $\mathrm{N} / \mathrm{A}$ & $\mathrm{N} / \mathrm{A}$ & N/A & N/A \\
\hline Hazardous waste handling and disposal & $\mathrm{N} / \mathrm{A}$ & $\mathrm{N} / \mathrm{A}$ & N/A & N/A \\
\hline \multicolumn{5}{|l|}{ Environmental Compliance } \\
\hline Staff time for permitting & $\mathrm{N} / \mathrm{A}$ & $\mathrm{N} / \mathrm{A}$ & $\mathrm{N} / \mathrm{A}$ & N/A \\
\hline Fees & $\mathrm{N} / \mathrm{A}$ & $\mathrm{N} / \mathrm{A}$ & N/A & N/A \\
\hline \multicolumn{5}{|l|}{ Vehicle Use (cost to gov't) } \\
\hline Fuel cost & $\mathrm{N} / \mathrm{A}$ & $\mathrm{N} / \mathrm{A}$ & N/A & N/A \\
\hline Security & $\mathrm{N} / \mathrm{A}$ & $\mathrm{N} / \mathrm{A}$ & N/A & N/A \\
\hline Pavement maintenance & $\mathrm{N} / \mathrm{A}$ & $\mathrm{N} / \mathrm{A}$ & $\mathrm{N} / \mathrm{A}$ & N/A \\
\hline \multicolumn{5}{|l|}{ Other } \\
\hline Market value of recyclables (70\% recovery) & $\mathrm{N} / \mathrm{A}$ & $\$(170,991)$ & N/A & $\$ 170,991$ \\
\hline $\begin{array}{lr}\text { Misc. } 2 \\
\end{array}$ & $\mathrm{~N} / \mathrm{A}$ & $\mathrm{N} / \mathrm{A}$ & N/A & $\mathrm{N} / \mathrm{A}$ \\
\hline Misc. 3 & $\mathrm{~N} / \mathrm{A}$ & $\mathrm{N} / \mathrm{A}$ & $\mathrm{N} / \mathrm{A}$ & N/A \\
\hline Misc. 4 & $\mathrm{~N} / \mathrm{A}$ & $\mathrm{N} / \mathrm{A}$ & N/A & N/A \\
\hline Misc. 5 & $\mathrm{~N} / \mathrm{A}$ & $\mathrm{N} / \mathrm{A}$ & N/A & N/A \\
\hline TOTAL Project Implementation Cost & & $\$ 571,851$ & & \\
\hline Total Annual Costs \& Savings & & $\$(16,334)$ & $\$ 190,525$ & $\$ 206,859$ \\
\hline
\end{tabular}




\section{Scenario \#2 building list}

Table A4 shows all the buildings (and associated collection containers) described in Scenario \#2, "Collection from Specific Building Types" (e.g., DFAC, GIB, TEMF, PX, and training barracks). Note that there are a few other building types that appear in this table. This is because some buildings are used for a number of different functions and therefore, some buildings are considered to be more than one building type. It is important to remember that, when collecting from a given building, it makes sense to collect from all areas of that building.

Table A4. Buildings in Scenario \#2 and collection containers required (ERDC-CERL, using building information from Fort Huachuca DPW).

\begin{tabular}{|c|c|c|c|c|c|c|c|c|}
\hline \multicolumn{4}{|c|}{ Building Info } & \multicolumn{5}{|c|}{ Containers } \\
\hline Bldg.\# & $\begin{array}{l}\text { Bldg.\# } \\
\text { Ext. }\end{array}$ & Organization & $\begin{array}{l}\text { Building } \\
\text { Type }\end{array}$ & $\begin{array}{l}\text { Exterior } \\
\text { OCC }\end{array}$ & $\begin{array}{l}\text { Exterior } \\
\text { Paper }\end{array}$ & $\begin{array}{l}\text { Exterior } \\
\text { Other }\end{array}$ & $\begin{array}{l}\text { Interior } \\
\text { Paper }\end{array}$ & $\begin{array}{l}\text { Interior } \\
\text { Other }\end{array}$ \\
\hline 11640 & & 2-13 AVN REGT & GIB & 1 & 1 & 1 & 6 & 6 \\
\hline 11640 & & 2-13 AVN REGT & GIB & 2 & 2 & 2 & 9 & 9 \\
\hline 15471 & & GOLF COURSE, FMWR & TEMF & & 0 & 0 & 1 & 1 \\
\hline 15472 & & GOLF COURSE, FMWR & TEMF & & 0 & 0 & 1 & 1 \\
\hline 15475 & & GOLF COURSE, FMWR & TEMF & & 0 & 0 & 1 & 1 \\
\hline 15476 & & GOLF COURSE, FMWR & TEMF & & 0 & 0 & 1 & 1 \\
\hline 15477 & & $\begin{array}{l}\text { MOUNTAIN VIEW GOLF } \\
\text { COURSE }\end{array}$ & TEMF & & 0 & 0 & 1 & 1 \\
\hline 15479 & & $\begin{array}{l}\text { MOUNTAIN VIEW GOLF } \\
\text { COURSE }\end{array}$ & PX & 2 & 1 & 1 & 2 & 2 \\
\hline 15482 & & GOLF COURSE, FMWR & TEMF & & 0 & 0 & 1 & 1 \\
\hline 15483 & & GOLF COURSE, FMWR & TEMF & & 0 & 0 & 1 & 1 \\
\hline 15491 & & $\begin{array}{l}\text { SHOPPETTE / MAIN } \\
\text { GATE }\end{array}$ & PX & 1 & 1 & 1 & 1 & 1 \\
\hline 21112 & & $\begin{array}{l}\text { Wayland Baptist } \\
\text { University }\end{array}$ & GIB & & 0 & 0 & 2 & 2 \\
\hline 21112 & & ACAP & GIB & 1 & 1 & 1 & 1 & 1 \\
\hline 22322 & & USA CPAC FT HUACHUCA & GIB & & 0 & 0 & 1 & 1 \\
\hline 22414 & & $\begin{array}{l}\text { TDY STUDENTS-BILLET } \\
\text { LOAD (SCHOOL CODE } \\
\text { 307) }\end{array}$ & GIB & & 1 & 1 & 4 & 4 \\
\hline 22414 & & REAL PROPERTY, DPW & GPW & 1 & 1 & 1 & 2 & 2 \\
\hline 22414 & & REAL PROPERTY, DPW & GPW & & 0 & 0 & 1 & 1 \\
\hline 22414 & & $\begin{array}{l}\text { TDY STUDENTS-BILLET } \\
\text { LOAD (SCHOOL CODE } \\
307 \text { ) }\end{array}$ & GPW & & 0 & 0 & 1 & 1 \\
\hline 22414 & & $\begin{array}{l}\text { DPW, USAG FT } \\
\text { HUACHUCA }\end{array}$ & GPW & & 0 & 0 & 1 & 1 \\
\hline
\end{tabular}




\begin{tabular}{|c|c|c|c|c|c|c|c|c|}
\hline \multicolumn{4}{|c|}{ Building Info } & \multicolumn{5}{|c|}{ Containers } \\
\hline Bldg.\# & $\begin{array}{l}\text { Bldg.\# } \\
\text { Ext. }\end{array}$ & Organization & $\begin{array}{l}\text { Building } \\
\text { Type }\end{array}$ & $\begin{array}{l}\text { Exterior } \\
\text { OCC }\end{array}$ & $\begin{array}{l}\text { Exterior } \\
\text { Paper }\end{array}$ & $\begin{array}{l}\text { Exterior } \\
\text { Other }\end{array}$ & $\begin{array}{l}\text { Interior } \\
\text { Paper }\end{array}$ & $\begin{array}{l}\text { Interior } \\
\text { Other }\end{array}$ \\
\hline 22414 & & $\begin{array}{l}\text { ARMY SUBSTANCE } \\
\text { ABUSE PROGRAM }\end{array}$ & $\mathrm{OHC}$ & & 1 & 1 & 4 & 4 \\
\hline 22530 & & $\begin{array}{l}\text { DPW, USAG FT } \\
\text { HUACHUCA }\end{array}$ & TEMF & 1 & 1 & 1 & 3 & 3 \\
\hline 30018 & & $\begin{array}{l}\text { ENG/HOUSE MNT } \\
\text { (HVAC) }\end{array}$ & TEMF & & 0 & 0 & 1 & 1 \\
\hline 30031 & & EMCOR & TEMF & & 0 & 0 & 1 & 1 \\
\hline 30033 & & EMCOR & TEMF & & 0 & 0 & 1 & 1 \\
\hline 30114 & & $\begin{array}{l}\text { USA OPTEC TEXCOM } \\
\text { IEWT DIR }\end{array}$ & TEMF & & 0 & 0 & 1 & 1 \\
\hline 30115 & & GAN & TEMF & 1 & 1 & 1 & 1 & 1 \\
\hline 30134 & & EMCOR & TEMF & & 0 & 0 & 2 & 2 \\
\hline 30138 & & CO D 306 MI BN & GIB & & 1 & 1 & 3 & 3 \\
\hline 31013 & & $\begin{array}{l}\text { DES, USAG FT } \\
\text { HUACHUCA }\end{array}$ & $\mathrm{GIB}$ & & 1 & 1 & 2 & 2 \\
\hline 31114 & & $\begin{array}{l}\text { DPW, USAG FT } \\
\text { HUACHUCA }\end{array}$ & TEMF & & 0 & 0 & 1 & 1 \\
\hline 41412 & & CO D 306 MI BN & GIB & & 1 & 1 & 5 & 5 \\
\hline 41416 & & CO D $306 \mathrm{MI}$ BN & GIB & & 2 & 2 & 6 & 6 \\
\hline 45103 & & Myer School & GIB & 2 & 3 & 3 & 15 & 15 \\
\hline 47121 & & Elementary School & GIB & 2 & 3 & 3 & 15 & 15 \\
\hline 51001 & & $\begin{array}{l}\text { BN 5TH BN, 104TH } \\
\text { REGT }\end{array}$ & BNHQ & 1 & 1 & 1 & 6 & 6 \\
\hline 51001 & & $\begin{array}{l}\text { BND GEN FORCE ARMY } \\
\text { BA }\end{array}$ & GIB & & 2 & 2 & 5 & 5 \\
\hline 51001 & & UPH HOUSING, DPW & $\begin{array}{l}\text { Training } \\
\text { Barracks }\end{array}$ & & 2 & 2 & 10 & 10 \\
\hline 51005 & & HHC USAICoE & BNHQ & & 1 & 1 & 4 & 4 \\
\hline 51005 & & 902nd MI GP & $\mathrm{COF}$ & & 0 & 0 & 2 & 2 \\
\hline 51005 & & CO E 2-13 Avn Regt & $\mathrm{COF}$ & & 0 & 0 & 1 & 1 \\
\hline 51005 & & Learning Innovation & GIB & & 1 & 1 & 3 & 3 \\
\hline 51005 & & 111TH MI BDE & $\begin{array}{l}\text { Training } \\
\text { Barracks }\end{array}$ & 1 & 9 & 9 & 45 & 45 \\
\hline 51005 & & COE 2-13 Avn Regt & $\begin{array}{l}\text { Training } \\
\text { Barracks }\end{array}$ & & 5 & 5 & 27 & 27 \\
\hline 51028 & & FIRE STATION \#1 & TEMF & & 1 & 1 & 1 & 1 \\
\hline 51424 & & REAL PROPERTY, DPW & TEMF & & 0 & 0 & 1 & 1 \\
\hline 51427 & & REAL PROPERTY, DPW & TEMF & & 0 & 0 & 1 & 1 \\
\hline 51428 & & REAL PROPERTY, DPW & TEMF & & 0 & 0 & 1 & 1 \\
\hline 51432 & & REAL PROPERTY, DPW & TEMF & & 0 & 0 & 1 & 1 \\
\hline 51450 & & AAFES & TEMF & & 0 & 0 & 2 & 2 \\
\hline 51451 & & $11 \mathrm{SC} B D E \mathrm{HHC}$ & TEMF & 2 & 2 & 2 & 1 & 1 \\
\hline 51452 & & REAL PROPERTY, DPW & GIB & & 0 & 0 & 1 & 1 \\
\hline
\end{tabular}




\begin{tabular}{|c|c|c|c|c|c|c|c|c|}
\hline \multicolumn{4}{|c|}{ Building Info } & \multicolumn{5}{|c|}{ Containers } \\
\hline Bldg.\# & $\begin{array}{l}\text { Bldg.\# } \\
\text { Ext. }\end{array}$ & Organization & $\begin{array}{l}\text { Building } \\
\text { Type }\end{array}$ & $\begin{array}{l}\text { Exterior } \\
\text { OCC }\end{array}$ & $\begin{array}{l}\text { Exterior } \\
\text { Paper }\end{array}$ & $\begin{array}{l}\text { Exterior } \\
\text { Other }\end{array}$ & $\begin{array}{l}\text { Interior } \\
\text { Paper }\end{array}$ & $\begin{array}{l}\text { Interior } \\
\text { Other }\end{array}$ \\
\hline 51453 & & REAL PROPERTY, DPW & TEMF & & 0 & 0 & 1 & 1 \\
\hline 51456 & & REAL PROPERTY, DPW & TEMF & & 0 & 0 & 1 & 1 \\
\hline 51457 & & REAL PROPERTY, DPW & TEMF & & 0 & 0 & 1 & 1 \\
\hline 51458 & & REAL PROPERTY, DPW & TEMF & & 0 & 0 & 1 & 1 \\
\hline 52008 & & CRAFT CENTER, FMWR & TEMF & 1 & 1 & 1 & 2 & 2 \\
\hline 52025 & & GAME STOP & PX & 1 & 0 & 0 & 1 & 1 \\
\hline 52030 & & MAIN EXCHANGE & PX & 2 & 3 & 3 & 15 & 15 \\
\hline 52038 & & SHOPPETTE / CLASS VI & PX & 2 & 0 & 0 & 1 & 1 \\
\hline 52045 & & Launderette & PX & 1 & 0 & 0 & 1 & 1 \\
\hline 52048 & & $\begin{array}{l}\text { PX FURNITURE / } \\
\text { OUTDOOR LIVING }\end{array}$ & PX & 2 & 0 & 0 & 3 & 3 \\
\hline 52104 & & $\begin{array}{l}\text { ARMY EDUCATION } \\
\text { CENTER }\end{array}$ & GIB & 1 & 2 & 2 & 6 & 6 \\
\hline 52107 & & BDE HHC THEAT TAC SIG & DFAC & 2 & 1 & 1 & 6 & 6 \\
\hline 52204 & & Safety Office & Office-Small & & 0 & 0 & 1 & 1 \\
\hline 52204 & & Union & Office-Small & & 0 & 0 & 1 & 1 \\
\hline 52204 & & UPH HOUSING, DPW & $\begin{array}{l}\text { Training } \\
\text { Barracks }\end{array}$ & 1 & 4 & 4 & 18 & 18 \\
\hline 52204 & & REAL PROPERTY, DPW & $\begin{array}{l}\text { Training } \\
\text { Barracks }\end{array}$ & & 0 & 0 & 1 & 1 \\
\hline 52308 & & REAL PROPERTY, DPW & BNHQ & & 1 & 1 & 4 & 4 \\
\hline 52308 & & $11 \mathrm{SC} B D E \mathrm{HHC}$ & GPW & & 1 & 1 & 2 & 2 \\
\hline 52308 & & WTU & $\begin{array}{l}\text { Training } \\
\text { Barracks }\end{array}$ & & 1 & 1 & 6 & 6 \\
\hline 52308 & & $11 \mathrm{SC} B D E \mathrm{HHC}$ & UEPH & & 4 & 4 & 22 & 22 \\
\hline 57439 & A & $\begin{array}{l}\text { DISA JOINT INTEROP } \\
\text { TEST CMD SPT }\end{array}$ & INFOSYS & & 0 & 0 & 2 & 2 \\
\hline 57439 & B & $\begin{array}{l}\text { DISA JOINT INTEROP } \\
\text { TEST CMD SPT }\end{array}$ & INFOSYS & & 1 & 1 & 4 & 4 \\
\hline 57439 & & $\begin{array}{l}\text { DISA JOINT INTEROP } \\
\text { TEST CMD SPT }\end{array}$ & TEMF & & 0 & 0 & 1 & 1 \\
\hline 61730 & & $\begin{array}{l}\text { W1E8AA CTR USA INT } \\
\text { CEN \& FT-04289 }\end{array}$ & GIB & & 1 & 1 & 4 & 4 \\
\hline 61730 & & $\begin{array}{l}\text { W1E8AA CTR USA INT } \\
\text { CEN \& FT-04289 }\end{array}$ & Office-Large & 1 & 5 & 5 & 27 & 27 \\
\hline 61730 & & Tradoc Culture Center & Office-Small & & 0 & 0 & 2 & 2 \\
\hline 61801 & & $\begin{array}{l}\text { WODA83 AMC/ASC } \\
\text { LOGISTICS SUPPORT } \\
\text { TEAM OVERHIRES }\end{array}$ & BNHQ & & 0 & 0 & 1 & 1 \\
\hline 61801 & & $\begin{array}{l}\text { DIS DISTRIBUTED } \\
\text { LEARNING SYSTEM }\end{array}$ & GIB & & 0 & 0 & 2 & 2 \\
\hline 61801 & & $\begin{array}{l}\text { ACT USA SIGNAL } \\
\text { NETWOR }\end{array}$ & GIB & & 0 & 0 & 2 & 2 \\
\hline 61801 & & CTR USA CIV PERS OPS & GIB & & 0 & 0 & 1 & 1 \\
\hline
\end{tabular}




\begin{tabular}{|c|c|c|c|c|c|c|c|c|}
\hline \multicolumn{4}{|c|}{ Building Info } & \multicolumn{5}{|c|}{ Containers } \\
\hline Bldg.\# & $\begin{array}{l}\text { Bldg.\# } \\
\text { Ext. }\end{array}$ & Organization & $\begin{array}{l}\text { Building } \\
\text { Type }\end{array}$ & $\begin{array}{l}\text { Exterior } \\
\text { OCC }\end{array}$ & $\begin{array}{l}\text { Exterior } \\
\text { Paper }\end{array}$ & $\begin{array}{l}\text { Exterior } \\
\text { Other }\end{array}$ & $\begin{array}{l}\text { Interior } \\
\text { Paper }\end{array}$ & $\begin{array}{l}\text { Interior } \\
\text { Other }\end{array}$ \\
\hline 61801 & & CTR USA CIV PERS OPS & GIB & & 0 & 0 & 1 & 1 \\
\hline 61801 & & $\begin{array}{l}\text { Communications } \\
\text { Security Logistics Activity } \\
\text { (CSLA) }\end{array}$ & GIB & & 0 & 0 & 1 & 1 \\
\hline 61801 & & CECOM & GIB & & 0 & 0 & 1 & 1 \\
\hline 61801 & & NETCOM & GPW & & 1 & 1 & 4 & 4 \\
\hline 61801 & & C-TNOSC & INFOSYS & & 3 & 3 & 14 & 14 \\
\hline 61801 & & $\begin{array}{l}\text { ACT USA SIGNAL } \\
\text { NETWOR }\end{array}$ & INFOSYS & & 1 & 1 & 7 & 7 \\
\hline 61801 & & $\begin{array}{l}\text { CMD USA INFO SYS } \\
\text { ENGR }\end{array}$ & INFOSYS & & 1 & 1 & 6 & 6 \\
\hline 61801 & & $\begin{array}{l}\text { DPTMS, USAG FT } \\
\text { HUACHUCA }\end{array}$ & INFOSYS & & 0 & 0 & 2 & 2 \\
\hline 61801 & & NETCOM & INFOSYS & & 0 & 0 & 1 & 1 \\
\hline 61801 & & NETCOM & Office-Large & 1 & 15 & 15 & 76 & 76 \\
\hline 61801 & & $\begin{array}{l}\text { Communications } \\
\text { Security Logistics Activity } \\
\text { (CSLA) }\end{array}$ & $\begin{array}{l}\text { Office- } \\
\text { Medium }\end{array}$ & & 3 & 3 & 17 & 17 \\
\hline 61801 & & $\begin{array}{l}\text { ACT USA SIGNAL } \\
\text { NETWOR }\end{array}$ & $\begin{array}{l}\text { Office- } \\
\text { Medium }\end{array}$ & & 2 & 2 & 12 & 12 \\
\hline 61801 & & CTR USA CIV PERS OPS & $\begin{array}{l}\text { Office- } \\
\text { Medium }\end{array}$ & & 2 & 2 & 11 & 11 \\
\hline 61801 & & C-TNOSC & $\begin{array}{l}\text { Office- } \\
\text { Medium }\end{array}$ & & 2 & 2 & 11 & 11 \\
\hline 61801 & & $\begin{array}{l}\text { CMD USA INFO SYS } \\
\text { ENGR }\end{array}$ & $\begin{array}{l}\text { Office- } \\
\text { Medium }\end{array}$ & & 1 & 1 & 7 & 7 \\
\hline 61801 & & $\mathrm{ACC}$ & $\begin{array}{l}\text { Office- } \\
\text { Medium }\end{array}$ & & 1 & 1 & 6 & 6 \\
\hline 61801 & & CECOM & $\begin{array}{l}\text { Office- } \\
\text { Medium }\end{array}$ & & 1 & 1 & 5 & 5 \\
\hline 61801 & & ISEC & $\begin{array}{l}\text { Office- } \\
\text { Medium }\end{array}$ & & 1 & 1 & 5 & 5 \\
\hline 61801 & & ACCAPG & Office-Small & & 1 & 1 & 3 & 3 \\
\hline 61801 & & W6UX RCERT 1 (CONUS) & Office-Small & & 1 & 1 & 3 & 3 \\
\hline 61801 & & REAL PROPERTY, DPW & Office-Small & & 1 & 1 & 3 & 3 \\
\hline 61801 & & CTR USA INT CEN \& FT & Office-Small & & 0 & 0 & 1 & 1 \\
\hline 61801 & & OPM INVESTIGATIVE SVC & Office-Small & & 0 & 0 & 1 & 1 \\
\hline 61801 & & CCIU TEAM C & Office-Small & & 0 & 0 & 1 & 1 \\
\hline 61801 & & C-TNOSC & $\mathrm{OHC}$ & & 1 & 1 & 3 & 3 \\
\hline 61801 & & AAFES & $P X$ & 2 & 1 & 1 & 2 & 2 \\
\hline 61801 & & NETCOM & Religious & & 1 & 1 & 4 & 4 \\
\hline 61801 & & SJA USAISC & Religious & & 0 & 0 & 1 & 1 \\
\hline 61809 & & CO B $305 \mathrm{Ml} \mathrm{BN}$ & GIB & 1 & 11 & 11 & 55 & 55 \\
\hline 61820 & & $305 \mathrm{Ml} \mathrm{BN}$ & GIB & & 4 & 4 & 20 & 20 \\
\hline
\end{tabular}




\begin{tabular}{|c|c|c|c|c|c|c|c|c|}
\hline \multicolumn{4}{|c|}{ Building Info } & \multicolumn{5}{|c|}{ Containers } \\
\hline Bldg.\# & $\begin{array}{l}\text { Bldg.\# } \\
\text { Ext. }\end{array}$ & Organization & $\begin{array}{l}\text { Building } \\
\text { Type }\end{array}$ & $\begin{array}{l}\text { Exterior } \\
\text { OCC }\end{array}$ & $\begin{array}{l}\text { Exterior } \\
\text { Paper }\end{array}$ & $\begin{array}{l}\text { Exterior } \\
\text { Other }\end{array}$ & $\begin{array}{l}\text { Interior } \\
\text { Paper }\end{array}$ & $\begin{array}{l}\text { Interior } \\
\text { Other }\end{array}$ \\
\hline 62702 & & CO C $304 \mathrm{Ml} \mathrm{BN}$ & GIB & 1 & 3 & 3 & 16 & 16 \\
\hline 62703 & & CO B 305 MI BN & GIB & & 1 & 1 & 3 & 3 \\
\hline 62703 & & CO A $305 \mathrm{Ml} \mathrm{BN}$ & GIB & & 0 & 0 & 2 & 2 \\
\hline 62703 & & CTR USA INT CEN \& FT & GIB & & 0 & 0 & 1 & 1 \\
\hline 62704 & & CTR USA INT CEN \& FT & GIB & 1 & 2 & 2 & 8 & 8 \\
\hline 62712 & & CISAC & GIB & & 2 & 2 & 9 & 9 \\
\hline 62715 & & CO A $309 \mathrm{Ml} \mathrm{BN}$ & GIB & & 1 & 1 & 3 & 3 \\
\hline 62718 & & NCO ACADEMY & $\begin{array}{l}\text { Training } \\
\text { Barracks }\end{array}$ & & 6 & 6 & 31 & 31 \\
\hline 62722 & & NCO ACADEMY & GIB & 1 & 3 & 3 & 13 & 13 \\
\hline 63845 & & CTR USA INT CEN \& FT & GIB & 1 & 5 & 5 & 27 & 27 \\
\hline 63845 & & CTR USA INT CEN \& FT & INFOSYS & & 0 & 0 & 1 & 1 \\
\hline 63902 & & CO A 305 MI BN & GIB & 2 & 5 & 5 & 23 & 23 \\
\hline 63902 & & 304TH MI BN & GIB & & 3 & 3 & 16 & 16 \\
\hline 63902 & & NCO ACADEMY & GIB & & 3 & 3 & 13 & 13 \\
\hline 63902 & & $\begin{array}{l}\text { CO E, HUMINT CMTE, Cl } \\
\text { DIVISION }\end{array}$ & GIB & & 0 & 0 & 1 & 1 \\
\hline 63902 & & USAICS COE & Office-Large & & 3 & 3 & 17 & 17 \\
\hline 70525 & & $\begin{array}{l}\text { THUNDER MOUNTAIN } \\
\text { ACTIVITY CENTER }\end{array}$ & DFAC & 2 & 2 & 2 & 12 & 12 \\
\hline 72805 & & BN EXPEDITIONARY SIG & TEMF & 1 & 1 & 1 & 5 & 5 \\
\hline 75801 & & $40 \mathrm{SCBN}$ & TEMF & 1 & 1 & 1 & 2 & 2 \\
\hline 75805 & & $40 \mathrm{SCBN}$ & TEMF & & 0 & 0 & 2 & 2 \\
\hline 75901 & & DOL FT HUACHUCA AZ & TEMF & & 0 & 0 & 3 & 3 \\
\hline 75902 & & DOL FT HUACHUCA AZ & TEMF & 1 & 1 & 1 & 2 & 2 \\
\hline 75903 & & DOL FT HUACHUCA AZ & TEMF & & 0 & 0 & 2 & 2 \\
\hline 80011 & & $\begin{array}{l}\text { CMD GLOBAL NETWORK } \\
\text { EN }\end{array}$ & GIB & & 0 & 0 & 1 & 1 \\
\hline 80011 & & CO D 306 MI BN & INFOSYS & 1 & 1 & 1 & 4 & 4 \\
\hline 80022 & A & $\begin{array}{l}\text { CO E, HUMINT CMTE, Cl } \\
\text { DIVISION }\end{array}$ & GIB & & 2 & 2 & 10 & 10 \\
\hline 80023 & A & $\begin{array}{l}\text { CO E, HUMINT CMTE, Cl } \\
\text { DIVISION }\end{array}$ & GIB & & 1 & 1 & 3 & 3 \\
\hline 80122 & & CO D $306 \mathrm{Ml} \mathrm{BN}$ & GIB & 2 & 5 & 5 & 25 & 25 \\
\hline 80405 & & $\begin{array}{l}\text { DPW, USAG FT } \\
\text { HUACHUCA }\end{array}$ & Office-Small & & 0 & 0 & 1 & 1 \\
\hline 80405 & & COA 213th & $\begin{array}{l}\text { Training } \\
\text { Barracks }\end{array}$ & 1 & 3 & 3 & 14 & 14 \\
\hline 80405 & & Marines Detachment & $\begin{array}{l}\text { Training } \\
\text { Barracks }\end{array}$ & & 2 & 2 & 8 & 8 \\
\hline 80406 & & CO D 305 MI BN & $\begin{array}{l}\text { Training } \\
\text { Barracks }\end{array}$ & 1 & 4 & 4 & 18 & 18 \\
\hline
\end{tabular}




\begin{tabular}{|c|c|c|c|c|c|c|c|c|}
\hline \multicolumn{4}{|c|}{ Building Info } & \multicolumn{5}{|c|}{ Containers } \\
\hline Bldg.\# & $\begin{array}{l}\text { Bldg.\# } \\
\text { Ext. }\end{array}$ & Organization & $\begin{array}{l}\text { Building } \\
\text { Type }\end{array}$ & $\begin{array}{l}\text { Exterior } \\
\text { OCC }\end{array}$ & $\begin{array}{l}\text { Exterior } \\
\text { Paper }\end{array}$ & $\begin{array}{l}\text { Exterior } \\
\text { Other }\end{array}$ & $\begin{array}{l}\text { Interior } \\
\text { Paper }\end{array}$ & $\begin{array}{l}\text { Interior } \\
\text { Other }\end{array}$ \\
\hline 80406 & & UPB Branch & $\begin{array}{l}\text { Training } \\
\text { Barracks }\end{array}$ & & 1 & 1 & 5 & 5 \\
\hline 80501 & & $\begin{array}{l}\text { MILITARY CLOTHING } \\
\text { STORE }\end{array}$ & PX & 2 & 0 & 0 & 2 & 2 \\
\hline 80503 & & REAL PROPERTY, DPW & DFAC & 2 & 1 & 1 & 6 & 6 \\
\hline 80504 & & REAL PROPERTY, DPW & DFAC & 2 & 1 & 1 & 6 & 6 \\
\hline 80505 & & CO A 304 MI BN & GIB & & 6 & 6 & 28 & 28 \\
\hline 80505 & & CO B 304 MI BN & $\overline{G I B}$ & & 2 & 2 & 5 & 5 \\
\hline 81305 & & CO B 305 MI BN & $\begin{array}{l}\text { Training } \\
\text { Barracks }\end{array}$ & 1 & 3 & 3 & 17 & 17 \\
\hline 81305 & & CO A 305 MI BN & $\begin{array}{l}\text { Training } \\
\text { Barracks }\end{array}$ & & 2 & 2 & 9 & 9 \\
\hline 81405 & & CO B 305 MI BN & $\begin{array}{l}\text { Training } \\
\text { Barracks }\end{array}$ & 1 & 2 & 2 & 9 & 9 \\
\hline 81405 & & 316 TRNG SQD, USAF & $\begin{array}{l}\text { Training } \\
\text { Barracks }\end{array}$ & & 1 & 1 & 6 & 6 \\
\hline 82502 & & MAINT FMX FHFO & TEMF & 1 & 1 & 1 & 5 & 5 \\
\hline 84402 & & CO B 309 MI BN & $\begin{array}{l}\text { Training } \\
\text { Barracks }\end{array}$ & 1 & 8 & 8 & 39 & 39 \\
\hline 85202 & & AIT Complex & DFAC & 2 & 3 & 3 & 13 & 13 \\
\hline 86302 & & CO A 309 MI BN & $\begin{array}{l}\text { Training } \\
\text { Barracks }\end{array}$ & 1 & 8 & 8 & 39 & 39 \\
\hline 86332 & & CO F $309 \mathrm{MI} \mathrm{BN}$ & $\begin{array}{l}\text { Training } \\
\text { Barracks }\end{array}$ & 1 & 8 & 8 & 39 & 39 \\
\hline 91110 & & COE 305 MI BN & TEMF & & 1 & 1 & 7 & 7 \\
\hline 91110 & & AIR TRAFFIC CONTROL & TEMF & & 0 & 0 & 1 & 1 \\
\hline 91114 & & 2-13 AVN REGT & TEMF & & 1 & 1 & 6 & 6 \\
\hline 91114 & & 160 SC BDE DUIC & TEMF & & 0 & 0 & 1 & 1 \\
\hline 91122 & & 2-13 AVN REGT & GIB & 1 & 3 & 3 & 14 & 14 \\
\hline 91253 & & FIRE STATION \#3 & TEMF & & 0 & 0 & 1 & 1 \\
\hline
\end{tabular}

\section{Scenario \#2 R0I calculation}

The groupings of spreadsheets in Table A5 represent the ROI and supporting calculations for Scenario \#2.

Table A5. ROI for Scenario \#2 (ERDC-CERL).

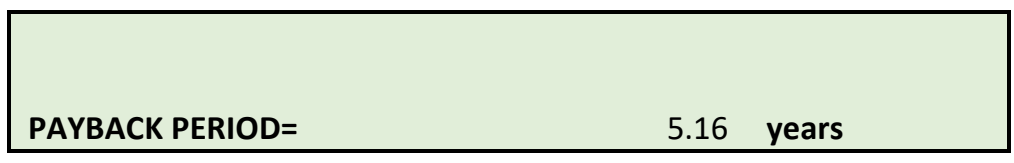




\begin{tabular}{|l|rrr|}
\hline One time cost & \$Current Practice & \$ New option & $\begin{array}{c}\text { Net Annual } \\
\text { savings }\end{array}$ \\
\cline { 2 - 4 } & & $\$ 259,646$ & \\
Annual cost & N/A & $\$(50,326)$ & $\$ 50,326$ \\
\hline
\end{tabular}

\begin{tabular}{|c|c|c|c|c|}
\hline Item & $\begin{array}{l}\text { \$Current } \\
\text { Practice }\end{array}$ & $\begin{array}{l}\text { \$ Proposed } \\
\text { Project }\end{array}$ & $\begin{array}{l}\$ \text { Net Annual } \\
\text { Project Cost, } \\
\text { by Line Item }\end{array}$ & $\begin{array}{l}\text { \$ Net Annual } \\
\text { Project Savings, by } \\
\text { Line Item }\end{array}$ \\
\hline \multicolumn{5}{|l|}{ One-time costs for new option } \\
\hline $\begin{array}{r}\text { Capital purchase, recycling containers at } 92 \\
\text { selected buildings }\end{array}$ & & $\$ 157,186$ & & \\
\hline Labor to set out containers (1 month) & & $\$ 9,600$ & & \\
\hline Connection to utilities, site & & N/A & & \\
\hline $\begin{array}{r}\text { Staff time for coordination, contracting, } \\
\text { etc. (one month) }\end{array}$ & & $\$ 14,400$ & & \\
\hline Outreach to installation, materials & & $\$ 20,000$ & & \\
\hline labels for bins @ \$20 ea. & & $\$ 58,460$ & & \\
\hline \multicolumn{5}{|l|}{ Annualized costs } \\
\hline \multicolumn{5}{|l|}{ Labor } \\
\hline DPW Staff labor (two months) & $\mathrm{N} / \mathrm{A}$ & $\$ 28,800$ & $\$ 28,800$ & N/A \\
\hline O\&M Labor, Gov't & $\mathrm{N} / \mathrm{A}$ & $\mathrm{N} / \mathrm{A}$ & $\mathrm{N} / \mathrm{A}$ & N/A \\
\hline Service calls & N/A & N/A & $\mathrm{N} / \mathrm{A}$ & N/A \\
\hline Contractor labor & N/A & N/A & $\mathrm{N} / \mathrm{A}$ & N/A \\
\hline Periodic training, outreach ( 80 hours) & N/A & $\$ 7,200$ & $\$ 7,200$ & N/A \\
\hline \multicolumn{5}{|l|}{ Parts } \\
\hline Consumables & $\mathrm{N} / \mathrm{A}$ & N/A & $\mathrm{N} / \mathrm{A}$ & N/A \\
\hline Parts & $\mathrm{N} / \mathrm{A}$ & N/A & $\mathrm{N} / \mathrm{A}$ & N/A \\
\hline \multicolumn{5}{|l|}{ Utilities } \\
\hline Electricity & N/A & N/A & $\mathrm{N} / \mathrm{A}$ & N/A \\
\hline Natural gas & N/A & N/A & $\mathrm{N} / \mathrm{A}$ & N/A \\
\hline Potable water & N/A & N/A & $\mathrm{N} / \mathrm{A}$ & N/A \\
\hline Sanitary sewer & $\mathrm{N} / \mathrm{A}$ & N/A & N/A & $\mathrm{N} / \mathrm{A}$ \\
\hline
\end{tabular}




\begin{tabular}{|c|c|c|c|c|}
\hline Item & $\begin{array}{l}\text { \$Current } \\
\text { Practice }\end{array}$ & $\begin{array}{l}\text { \$ Proposed } \\
\text { Project }\end{array}$ & $\begin{array}{l}\text { \$ Net Annual } \\
\text { Project Cost, } \\
\text { by Line Item }\end{array}$ & $\begin{array}{l}\text { \$ Net Annual } \\
\text { Project Savings, by } \\
\text { Line Item }\end{array}$ \\
\hline Liquid fuels & N/A & $\mathrm{N} / \mathrm{A}$ & N/A & N/A \\
\hline \multicolumn{5}{|l|}{ Waste } \\
\hline $\begin{array}{r}\text { Avoided tipping fees (1109 tons @ } \\
\$ 35 / \text { ton) * 70\% recovery rate }\end{array}$ & N/A & $\$(27,171)$ & N/A & $\$ 27,171$ \\
\hline $\begin{array}{r}\text { Additional cost for hauling recyclables } \\
\text { (1464 tons @ } \$ 90.42 / \text { ton) } * 70 \% \text { recovery } \\
\text { rate }\end{array}$ & $\mathrm{N} / \mathrm{A}$ & $\$ 70,193$ & $\$ 70,193$ & N/A \\
\hline Hazardous waste handling and disposal & N/A & $\$-$ & N/A & $\mathrm{N} / \mathrm{A}$ \\
\hline \multicolumn{5}{|l|}{ Environmental Compliance } \\
\hline Staff time for permitting & N/A & N/A & $\mathrm{N} / \mathrm{A}$ & N/A \\
\hline Fees & N/A & $\mathrm{N} / \mathrm{A}$ & N/A & N/A \\
\hline \multicolumn{5}{|l|}{ Vehicle Usage (cost to gov't) } \\
\hline Fuel cost & $\mathrm{N} / \mathrm{A}$ & N/A & $\mathrm{N} / \mathrm{A}$ & N/A \\
\hline Security & N/A & N/A & $\mathrm{N} / \mathrm{A}$ & N/A \\
\hline Pavement maintenance & N/A & $\mathrm{N} / \mathrm{A}$ & N/A & N/A \\
\hline \multicolumn{5}{|l|}{ Other } \\
\hline Market value of recyclables ( $70 \%$ recovery) & N/A & $\$(129,349)$ & N/A & $\$ 129,349$ \\
\hline Misc. 2 & $\mathrm{~N} / \mathrm{A}$ & $\mathrm{N} / \mathrm{A}$ & N/A & $\mathrm{N} / \mathrm{A}$ \\
\hline Misc. 3 & N/A & $\mathrm{N} / \mathrm{A}$ & N/A & N/A \\
\hline Misc. 4 & N/A & $\mathrm{N} / \mathrm{A}$ & N/A & N/A \\
\hline Misc. 5 & $\mathrm{~N} / \mathrm{A}$ & $\mathrm{N} / \mathrm{A}$ & N/A & N/A \\
\hline TOTAL Project Implementation cost & & $\$ 259,646$ & & \\
\hline Total Annual cost $\&$ savings & N/A & $\$(50,326)$ & $\$ 106,193$ & $\$ 156,519$ \\
\hline
\end{tabular}

\section{Scenario \#3 building list}

Table A6 lists the buildings considered in Scenario \# 3 and the number of containers (interior and exterior) needed per building by type of recyclable material. Note that some building numbers appear on multiple rows. That's because it's a large building with multiple functions. 
Table A6. Scenario \#3 building list and number of recycling containers needed per building (ERDC-CERL, with building details supplied by Fort Huachuca DPW).

\begin{tabular}{|c|c|c|c|c|c|c|c|c|}
\hline \multicolumn{4}{|c|}{ Building Info } & \multicolumn{5}{|c|}{ Number of Containers } \\
\hline $\begin{array}{l}\text { Building } \\
\#\end{array}$ & $\begin{array}{l}\text { Bldg. } \\
\text { \# ext. }\end{array}$ & Organization & $\begin{array}{l}\text { Building } \\
\text { Type }\end{array}$ & $\begin{array}{l}\text { Exterior } \\
\text { OCC }\end{array}$ & $\begin{array}{l}\text { Exterior } \\
\text { paper }\end{array}$ & $\begin{array}{l}\text { Exterior } \\
\text { Other }\end{array}$ & $\begin{array}{l}\text { Interior } \\
\text { Paper }\end{array}$ & $\begin{array}{l}\text { Interior } \\
\text { Other }\end{array}$ \\
\hline 11640 & & 2-13 AVN REGT & GIB & 1 & 1 & 1 & 6 & 6 \\
\hline 11640 & & 2-13 AVN REGT & GIB & 2 & 2 & 2 & 9 & 9 \\
\hline 45001 & & $\begin{array}{l}\text { RAYMOND W. } \\
\text { BLISS CLINIC }\end{array}$ & $\begin{array}{l}\text { Healthcare } \\
\text { - Hospital }\end{array}$ & 2 & 9 & 9 & 44 & 44 \\
\hline 48101 & & CDC, FMWR & CDC & 2 & 2 & 2 & 11 & 11 \\
\hline 49055 & & CDC, FMWR & $\mathrm{CDC}$ & 2 & 2 & 2 & 8 & 8 \\
\hline 51005 & & HHC USAICOE & $\mathrm{BNHQ}$ & & 1 & 1 & 4 & 4 \\
\hline 51005 & & 902nd MI GP & COF & & 0 & 0 & 2 & 2 \\
\hline 51005 & & $\begin{array}{l}\text { CO E 2-13 } \\
\text { Avn Regt }\end{array}$ & COF & & 0 & 0 & 1 & 1 \\
\hline 51005 & & $\begin{array}{l}\text { Learning } \\
\text { Innovation }\end{array}$ & GIB & & 1 & 1 & 3 & 3 \\
\hline 51005 & & ARNG & $\begin{array}{l}\text { Office- } \\
\text { Small }\end{array}$ & & 1 & 1 & 3 & 3 \\
\hline 51005 & & ITRADS & $\begin{array}{l}\text { Office- } \\
\text { Small }\end{array}$ & & 0 & 0 & 2 & 2 \\
\hline 51005 & & $\begin{array}{l}\text { Judge Advocate } \\
\text { Generals }\end{array}$ & $\begin{array}{l}\text { Office- } \\
\text { Small }\end{array}$ & & 0 & 0 & 1 & 1 \\
\hline 51005 & & $\begin{array}{l}\text { W3ZU USA } \\
\text { DENTAL ACT }\end{array}$ & $\mathrm{OHC}$ & & 0 & 0 & 1 & 1 \\
\hline 51005 & & 111TH MI BDE & $\begin{array}{l}\text { Training } \\
\text { Barracks }\end{array}$ & 1 & 9 & 9 & 45 & 45 \\
\hline 51005 & & $\begin{array}{l}\text { CO E 2-13 Avn } \\
\text { Regt }\end{array}$ & $\begin{array}{l}\text { Training } \\
\text { Barracks }\end{array}$ & & 5 & 5 & 27 & 27 \\
\hline 52030 & & MAIN EXCHANGE & $\mathrm{PX}$ & 2 & 3 & 3 & 15 & 15 \\
\hline 52056 & & $\begin{array}{l}\text { CYS SERVICES, } \\
\text { FMWR }\end{array}$ & $\mathrm{CDC}$ & 2 & 2 & 2 & 12 & 12 \\
\hline 52107 & & $\begin{array}{l}\text { BDE HHC THEAT } \\
\text { TAC SIG }\end{array}$ & DFAC & 2 & 1 & 1 & 6 & 6 \\
\hline 53301 & & $\begin{array}{l}\text { TECHNOLOGY } \\
\text { INTERGRATION } \\
\text { CENTER }\end{array}$ & INFOSYS & 1 & 4 & 4 & 19 & 19 \\
\hline 53302 & & $\begin{array}{l}\text { TECHNOLOGY } \\
\text { INTERGRATION } \\
\text { CENTER }\end{array}$ & INFOSYS & & 4 & 4 & 19 & 19 \\
\hline
\end{tabular}




\begin{tabular}{|c|c|c|c|c|c|c|c|c|}
\hline \multicolumn{4}{|c|}{ Building Info } & \multicolumn{5}{|c|}{ Number of Containers } \\
\hline $\begin{array}{l}\text { Building } \\
\text { \# }\end{array}$ & $\begin{array}{l}\text { Bldg. } \\
\text { \# ext. }\end{array}$ & Organization & $\begin{array}{l}\text { Building } \\
\text { Type }\end{array}$ & $\begin{array}{l}\text { Exterior } \\
\text { OCC }\end{array}$ & $\begin{array}{l}\text { Exterior } \\
\text { paper }\end{array}$ & $\begin{array}{l}\text { Exterior } \\
\text { Other }\end{array}$ & $\begin{array}{l}\text { Interior } \\
\text { Paper }\end{array}$ & $\begin{array}{l}\text { Interior } \\
\text { Other }\end{array}$ \\
\hline 57305 & $A$ & $\begin{array}{l}\text { DISA JOINT } \\
\text { INTEROP TEST } \\
\text { CMD SPT }\end{array}$ & INFOSYS & & 1 & 1 & 5 & 5 \\
\hline 57305 & & $\begin{array}{l}\text { DISA JOINT } \\
\text { INTEROP TEST } \\
\text { CMD SPT }\end{array}$ & INFOSYS & 1 & 8 & 8 & 41 & 41 \\
\hline 57428 & $A$ & $\begin{array}{l}\text { DISA JOINT } \\
\text { INTEROP TEST } \\
\text { CMD SPT }\end{array}$ & INFOSYS & & 1 & 1 & 3 & 3 \\
\hline 57428 & $\mathrm{~B}$ & $\begin{array}{l}\text { DISA JOINT } \\
\text { INTEROP TEST } \\
\text { CMD SPT }\end{array}$ & INFOSYS & & 1 & 1 & 3 & 3 \\
\hline 57428 & C & $\begin{array}{l}\text { DISA JOINT } \\
\text { INTEROP TEST } \\
\text { CMD SPT }\end{array}$ & INFOSYS & & 1 & 1 & 3 & 3 \\
\hline 57428 & $\mathrm{D}$ & $\begin{array}{l}\text { DISA JOINT } \\
\text { INTEROP TEST } \\
\text { CMD SPT }\end{array}$ & INFOSYS & & 1 & 1 & 3 & 3 \\
\hline 57428 & $E$ & $\begin{array}{l}\text { DISA JOINT } \\
\text { INTEROP TEST } \\
\text { CMD SPT }\end{array}$ & INFOSYS & & 1 & 1 & 3 & 3 \\
\hline 57428 & $\mathrm{~F}$ & $\begin{array}{l}\text { DISA JOINT } \\
\text { INTEROP TEST } \\
\text { CMD SPT }\end{array}$ & INFOSYS & & 1 & 1 & 4 & 4 \\
\hline 57428 & & $\begin{array}{l}\text { DISA JOINT } \\
\text { INTEROP TEST } \\
\text { CMD SPT }\end{array}$ & INFOSYS & 1 & 2 & 2 & 8 & 8 \\
\hline 61801 & & $\begin{array}{l}\text { WODA83 } \\
\text { AMC/ASC } \\
\text { LOGISTICS } \\
\text { SUPPORT TEAM } \\
\text { OVERHIRES }\end{array}$ & BNHQ & & 0 & 0 & 1 & 1 \\
\hline 61801 & & $\begin{array}{l}\text { DIS DISTRIBUTED } \\
\text { LEARNING } \\
\text { SYSTEM }\end{array}$ & GIB & & 0 & 0 & 2 & 2 \\
\hline 61801 & & $\begin{array}{l}\text { ACT USA SIGNAL } \\
\text { NETWOR }\end{array}$ & GIB & & 0 & 0 & 2 & 2 \\
\hline 61801 & & $\begin{array}{l}\text { CTR USA CIV } \\
\text { PERS OPS }\end{array}$ & GIB & & 0 & 0 & 1 & 1 \\
\hline
\end{tabular}




\begin{tabular}{|c|c|c|c|c|c|c|c|c|}
\hline \multicolumn{4}{|c|}{ Building Info } & \multicolumn{5}{|c|}{ Number of Containers } \\
\hline $\begin{array}{l}\text { Building } \\
\text { \# }\end{array}$ & $\begin{array}{l}\text { Bldg. } \\
\text { \# ext. }\end{array}$ & Organization & $\begin{array}{l}\text { Building } \\
\text { Type }\end{array}$ & $\begin{array}{l}\text { Exterior } \\
\text { OCC }\end{array}$ & $\begin{array}{l}\text { Exterior } \\
\text { paper }\end{array}$ & $\begin{array}{l}\text { Exterior } \\
\text { Other }\end{array}$ & $\begin{array}{l}\text { Interior } \\
\text { Paper }\end{array}$ & $\begin{array}{l}\text { Interior } \\
\text { Other }\end{array}$ \\
\hline 61801 & & $\begin{array}{l}\text { CTR USA CIV } \\
\text { PERS OPS }\end{array}$ & GIB & & 0 & 0 & 1 & 1 \\
\hline 61801 & & $\begin{array}{l}\text { Communications } \\
\text { Security Logistics } \\
\text { Activity (CSLA) }\end{array}$ & GIB & & 0 & 0 & 1 & 1 \\
\hline 61801 & & CECOM & GIB & & 0 & 0 & 1 & 1 \\
\hline 61801 & & NETCOM & GPW & & 1 & 1 & 4 & 4 \\
\hline 61801 & & C-TNOSC & INFOSYS & & 3 & 3 & 14 & 14 \\
\hline 61801 & & $\begin{array}{l}\text { ACT USA SIGNAL } \\
\text { NETWOR }\end{array}$ & INFOSYS & & 1 & 1 & 7 & 7 \\
\hline 61801 & & $\begin{array}{l}\text { CMD USA INFO } \\
\text { SYS ENGR }\end{array}$ & INFOSYS & & 1 & 1 & 6 & 6 \\
\hline 61801 & & $\begin{array}{l}\text { DPTMS, USAG FT } \\
\text { HUACHUCA }\end{array}$ & INFOSYS & & 0 & 0 & 2 & 2 \\
\hline 61801 & & NETCOM & INFOSYS & & 0 & 0 & 1 & 1 \\
\hline 61801 & & NETCOM & $\begin{array}{l}\text { Office- } \\
\text { Large }\end{array}$ & 1 & 15 & 15 & 76 & 76 \\
\hline 61801 & & $\begin{array}{l}\text { Communications } \\
\text { Security Logistics } \\
\text { Activity (CSLA) }\end{array}$ & $\begin{array}{l}\text { Office- } \\
\text { Medium }\end{array}$ & & 3 & 3 & 17 & 17 \\
\hline 61801 & & $\begin{array}{l}\text { ACT USA SIGNAL } \\
\text { NETWOR }\end{array}$ & $\begin{array}{l}\text { Office- } \\
\text { Medium }\end{array}$ & & 2 & 2 & 12 & 12 \\
\hline 61801 & & $\begin{array}{l}\text { CTR USA CIV } \\
\text { PERS OPS }\end{array}$ & $\begin{array}{l}\text { Office- } \\
\text { Medium }\end{array}$ & & 2 & 2 & 11 & 11 \\
\hline 61801 & & C-TNOSC & $\begin{array}{l}\text { Office- } \\
\text { Medium }\end{array}$ & & 2 & 2 & 11 & 11 \\
\hline 61801 & & $\begin{array}{l}\text { CMD USA INFO } \\
\text { SYS ENGR }\end{array}$ & $\begin{array}{l}\text { Office- } \\
\text { Medium }\end{array}$ & & 1 & 1 & 7 & 7 \\
\hline 61801 & & ACC & $\begin{array}{l}\text { Office- } \\
\text { Medium }\end{array}$ & & 1 & 1 & 6 & 6 \\
\hline 61801 & & CECOM & $\begin{array}{l}\text { Office- } \\
\text { Medium }\end{array}$ & & 1 & 1 & 5 & 5 \\
\hline 61801 & & ISEC & $\begin{array}{l}\text { Office- } \\
\text { Medium }\end{array}$ & & 1 & 1 & 5 & 5 \\
\hline 61801 & & ACCAPG & $\begin{array}{l}\text { Office- } \\
\text { Small }\end{array}$ & & 1 & 1 & 3 & 3 \\
\hline 61801 & & $\begin{array}{l}\text { W6UX RCERT } 1 \\
\text { (CONUS) }\end{array}$ & $\begin{array}{l}\text { Office- } \\
\text { Small }\end{array}$ & & 1 & 1 & 3 & 3 \\
\hline
\end{tabular}




\begin{tabular}{|c|c|c|c|c|c|c|c|c|}
\hline \multicolumn{4}{|c|}{ Building Info } & \multicolumn{5}{|c|}{ Number of Containers } \\
\hline $\begin{array}{l}\text { Building } \\
\text { \# }\end{array}$ & $\begin{array}{l}\text { Bldg. } \\
\text { \# ext. }\end{array}$ & Organization & $\begin{array}{l}\text { Building } \\
\text { Type }\end{array}$ & $\begin{array}{l}\text { Exterior } \\
\text { OCC }\end{array}$ & $\begin{array}{l}\text { Exterior } \\
\text { paper }\end{array}$ & $\begin{array}{l}\text { Exterior } \\
\text { Other }\end{array}$ & $\begin{array}{l}\text { Interior } \\
\text { Paper }\end{array}$ & $\begin{array}{l}\text { Interior } \\
\text { Other }\end{array}$ \\
\hline 61801 & & $\begin{array}{l}\text { REAL PROPERTY, } \\
\text { DPW }\end{array}$ & $\begin{array}{l}\text { Office- } \\
\text { Small }\end{array}$ & & 1 & 1 & 3 & 3 \\
\hline 61801 & & $\begin{array}{l}\text { CTR USA INT CEN } \\
\& \text { FT }\end{array}$ & $\begin{array}{l}\text { Office- } \\
\text { Small }\end{array}$ & & 0 & 0 & 1 & 1 \\
\hline 61801 & & $\begin{array}{l}\text { OPM } \\
\text { INVESTIGATIVE } \\
\text { SVC }\end{array}$ & $\begin{array}{l}\text { Office- } \\
\text { Small }\end{array}$ & & 0 & 0 & 1 & 1 \\
\hline 61801 & & CCIU TEAM C & $\begin{array}{l}\text { Office- } \\
\text { Small }\end{array}$ & & 0 & 0 & 1 & 1 \\
\hline 61801 & & C-TNOSC & $\mathrm{OHC}$ & & 1 & 1 & 3 & 3 \\
\hline 61801 & & AAFES & PX & 2 & 1 & 1 & 2 & 2 \\
\hline 61801 & & NETCOM & Religious & & 1 & 1 & 4 & 4 \\
\hline 61801 & & SJA USAISC & Religious & & 0 & 0 & 1 & 1 \\
\hline 61809 & & CO B 305 MI BN & GIB & 1 & 11 & 11 & 55 & 55 \\
\hline 61820 & & $305 \mathrm{MI} \mathrm{BN}$ & GIB & & 4 & 4 & 20 & 20 \\
\hline 63845 & & $\begin{array}{l}\text { CTR USA INT CEN } \\
\& \text { FT }\end{array}$ & GIB & 1 & 5 & 5 & 27 & 27 \\
\hline 63845 & & $\begin{array}{l}\text { CTR USA INT CEN } \\
\& \text { FT }\end{array}$ & INFOSYS & & 0 & 0 & 1 & 1 \\
\hline 63902 & & CO A 305 MI BN & GIB & 2 & 5 & 5 & 23 & 23 \\
\hline 63902 & & 304TH MI BN & GIB & & 3 & 3 & 16 & 16 \\
\hline 63902 & & NCO ACADEMY & GIB & & 3 & 3 & 13 & 13 \\
\hline 63902 & & $\begin{array}{l}\text { CO E, HUMINT } \\
\text { CMTE, Cl } \\
\text { DIVISION }\end{array}$ & GIB & & 0 & 0 & 1 & 1 \\
\hline 63902 & & USAICS COE & $\begin{array}{l}\text { Office- } \\
\text { Large }\end{array}$ & & 3 & 3 & 17 & 17 \\
\hline 70525 & & $\begin{array}{l}\text { THUNDER } \\
\text { MOUNTAIN } \\
\text { ACTIVITY CENTER }\end{array}$ & DFAC & 2 & 2 & 2 & 12 & 12 \\
\hline 80122 & & CO D $306 \mathrm{MI} \mathrm{BN}$ & GIB & 2 & 5 & 5 & 25 & 25 \\
\hline 80503 & & $\begin{array}{l}\text { REAL PROPERTY, } \\
\text { DPW }\end{array}$ & DFAC & 2 & 1 & 1 & 6 & 6 \\
\hline 80504 & & $\begin{array}{l}\text { REAL PROPERTY, } \\
\text { DPW }\end{array}$ & DFAC & 2 & 1 & 1 & 6 & 6 \\
\hline 80505 & & CO A 304 MI BN & GIB & & 6 & 6 & 28 & 28 \\
\hline 80505 & & CO B 304 MI BN & GIB & & 2 & 2 & 5 & 5 \\
\hline
\end{tabular}




\begin{tabular}{|l|l|l|l|l|l|l|l|l|}
\hline \multicolumn{3}{|c}{ Building Info } & \multicolumn{5}{c|}{ Number of Containers } \\
\hline $\begin{array}{l}\text { Building } \\
\#\end{array}$ & $\begin{array}{l}\text { Bldg. } \\
\text { \# ext. }\end{array}$ & Organization & $\begin{array}{l}\text { Building } \\
\text { Type }\end{array}$ & $\begin{array}{l}\text { Exterior } \\
\text { OCC }\end{array}$ & $\begin{array}{l}\text { Exterior } \\
\text { paper }\end{array}$ & $\begin{array}{l}\text { Exterior } \\
\text { Other }\end{array}$ & $\begin{array}{l}\text { Interior } \\
\text { Paper }\end{array}$ & $\begin{array}{l}\text { Interior } \\
\text { Other }\end{array}$ \\
\hline 85202 & & AIT Complex & DFAC & 2 & 3 & 3 & 13 & 13 \\
\hline 91122 & & 2-13 AVN REGT & GIB & 1 & 3 & 3 & 14 & 14 \\
\hline
\end{tabular}

\section{Scenario \#3 ROI calculation}

The groupings of spreadsheets in Table A7 represent the ROI and supporting calculations for Scenario \# 3 .

Table A7. ROI for Scenario \#3 (ERDC-CERL).

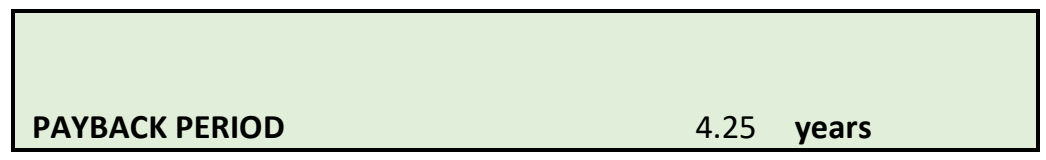

\begin{tabular}{|lrrr|}
\hline & \$Current Practice & \$ New option & $\begin{array}{c}\text { Net Annual } \\
\text { savings }\end{array}$ \\
\hline One time cost & & $\$ 174,465$ & \\
Annual cost & N/A & $\$(41,077)$ & $\$ 41,077$ \\
\hline
\end{tabular}

\begin{tabular}{|c|c|c|c|c|}
\hline Item & $\begin{array}{l}\text { \$ Current } \\
\text { Practice }\end{array}$ & $\begin{array}{l}\text { \$ Proposed } \\
\text { Project }\end{array}$ & $\begin{array}{l}\text { \$ Net Annual } \\
\text { Project Cost, by } \\
\text { Line Item }\end{array}$ & $\begin{array}{l}\text { \$ Net Annual } \\
\text { Project Savings, by } \\
\text { Line Item }\end{array}$ \\
\hline \multicolumn{5}{|l|}{ One-time costs for new option } \\
\hline $\begin{array}{r}\text { Capital purchase, recycling containers, at } \\
25 \text { selected buildings }\end{array}$ & & $\$ 95,885$ & & \\
\hline Labor to set out containers ( 2 weeks) & & $\$ 4,800$ & & \\
\hline Connection to utilities, site & & N/A & & \\
\hline $\begin{array}{r}\text { Staff time for coordination, contracting, } \\
\text { etc. (one month) }\end{array}$ & & $\$ 14,400$ & & \\
\hline Outreach to installation, materials & & $\$ 20,000$ & & \\
\hline labels for bins @ \$20 ea. & & $\$ 39,380$ & & \\
\hline \multicolumn{5}{|l|}{ Annualized costs } \\
\hline \multicolumn{5}{|l|}{ Labor } \\
\hline DPW Staff labor (one month) & N/A & $\$ 14,400$ & $\$ 14,400$ & $\mathrm{~N} / \mathrm{A}$ \\
\hline
\end{tabular}




\begin{tabular}{|c|c|c|c|c|}
\hline Item & $\begin{array}{l}\text { \$Current } \\
\text { Practice }\end{array}$ & $\begin{array}{l}\text { \$ Proposed } \\
\text { Project }\end{array}$ & $\begin{array}{l}\text { \$ Net Annual } \\
\text { Project Cost, by } \\
\text { Line Item }\end{array}$ & $\begin{array}{l}\text { \$ Net Annual } \\
\text { Project Savings, by } \\
\text { Line Item }\end{array}$ \\
\hline O\&M Labor, Gov't & $\mathrm{N} / \mathrm{A}$ & $\mathrm{N} / \mathrm{A}$ & $\mathrm{N} / \mathrm{A}$ & $\mathrm{N} / \mathrm{A}$ \\
\hline Service calls & $\mathrm{N} / \mathrm{A}$ & N/A & $\mathrm{N} / \mathrm{A}$ & $\mathrm{N} / \mathrm{A}$ \\
\hline Contractor labor & $\mathrm{N} / \mathrm{A}$ & $\mathrm{N} / \mathrm{A}$ & N/A & N/A \\
\hline Periodic training, outreach ( 80 hours) & $\mathrm{N} / \mathrm{A}$ & $\$ 7,200$ & $\$ 7,200$ & $\mathrm{~N} / \mathrm{A}$ \\
\hline \multicolumn{5}{|l|}{ Parts } \\
\hline Consumables & $\mathrm{N} / \mathrm{A}$ & $\mathrm{N} / \mathrm{A}$ & $\mathrm{N} / \mathrm{A}$ & $\mathrm{N} / \mathrm{A}$ \\
\hline Parts & $\mathrm{N} / \mathrm{A}$ & $\mathrm{N} / \mathrm{A}$ & N/A & $\mathrm{N} / \mathrm{A}$ \\
\hline \multicolumn{5}{|l|}{ Utilities } \\
\hline Electricity & N/A & $\mathrm{N} / \mathrm{A}$ & N/A & $\mathrm{N} / \mathrm{A}$ \\
\hline Natural gas & $\mathrm{N} / \mathrm{A}$ & $\mathrm{N} / \mathrm{A}$ & N/A & N/A \\
\hline Potable water & $\mathrm{N} / \mathrm{A}$ & $\mathrm{N} / \mathrm{A}$ & N/A & $\mathrm{N} / \mathrm{A}$ \\
\hline Sanitary sewer & $\mathrm{N} / \mathrm{A}$ & $\mathrm{N} / \mathrm{A}$ & N/A & $\mathrm{N} / \mathrm{A}$ \\
\hline Liquid fuels & $\mathrm{N} / \mathrm{A}$ & $\mathrm{N} / \mathrm{A}$ & $\mathrm{N} / \mathrm{A}$ & N/A \\
\hline \multicolumn{5}{|l|}{ Waste } \\
\hline $\begin{array}{r}\text { Avoided tipping fees (1843 tons @ } \\
\$ 35 / \text { ton) * 70\% recovery rate }\end{array}$ & $\mathrm{N} / \mathrm{A}$ & $\$(20,654)$ & N/A & $\$ 20,654$ \\
\hline $\begin{array}{l}\text { Additional cost for hauling recyclables ( } 843 \\
\text { tons @ } \$ 90.42 / \text { ton) } * 70 \% \text { recovery rate }\end{array}$ & N/A & $\$ 53,357$ & $\$ 53,357$ & N/A \\
\hline Hazardous waste handling and disposal & $\mathrm{N} / \mathrm{A}$ & N/A & N/A & $\mathrm{N} / \mathrm{A}$ \\
\hline \multicolumn{5}{|l|}{ Environmental Compliance } \\
\hline Staff time for permitting & N/A & $\mathrm{N} / \mathrm{A}$ & $\mathrm{N} / \mathrm{A}$ & $\mathrm{N} / \mathrm{A}$ \\
\hline Fees & $\mathrm{N} / \mathrm{A}$ & $\mathrm{N} / \mathrm{A}$ & $\mathrm{N} / \mathrm{A}$ & $\mathrm{N} / \mathrm{A}$ \\
\hline \multicolumn{5}{|l|}{ Vehicle Usage (cost to gov't } \\
\hline Fuel cost & N/A & $\mathrm{N} / \mathrm{A}$ & N/A & $\mathrm{N} / \mathrm{A}$ \\
\hline Security & $\mathrm{N} / \mathrm{A}$ & $\mathrm{N} / \mathrm{A}$ & $\mathrm{N} / \mathrm{A}$ & $\mathrm{N} / \mathrm{A}$ \\
\hline Pavement maintenance & $\mathrm{N} / \mathrm{A}$ & $\mathrm{N} / \mathrm{A}$ & $\mathrm{N} / \mathrm{A}$ & $\mathrm{N} / \mathrm{A}$ \\
\hline \multicolumn{5}{|l|}{ Other } \\
\hline Market value of recyclables ( $70 \%$ recovery) & $\mathrm{N} / \mathrm{A}$ & $\$(95,381)$ & $\mathrm{N} / \mathrm{A}$ & $\$ 95,381$ \\
\hline $\begin{array}{ll} & \text { Misc. } 2 \\
\end{array}$ & $\mathrm{~N} / \mathrm{A}$ & $\mathrm{N} / \mathrm{A}$ & N/A & $\$-$ \\
\hline Misc. 3 & $\mathrm{~N} / \mathrm{A}$ & $\mathrm{N} / \mathrm{A}$ & N/A & $\mathrm{N} / \mathrm{A}$ \\
\hline Misc. 4 & $\mathrm{~N} / \mathrm{A}$ & $\mathrm{N} / \mathrm{A}$ & N/A & N/A \\
\hline Misc. 5 & $\mathrm{~N} / \mathrm{A}$ & $\mathrm{N} / \mathrm{A}$ & N/A & N/A \\
\hline
\end{tabular}




\begin{tabular}{|c|c|c|c|c|}
\hline Item & $\begin{array}{l}\text { \$ Current } \\
\text { Practice }\end{array}$ & $\begin{array}{l}\text { \$ Proposed } \\
\text { Project }\end{array}$ & $\begin{array}{l}\text { \$ Net Annual } \\
\text { Project Cost, by } \\
\text { Line Item }\end{array}$ & $\begin{array}{l}\text { \$ Net Annual } \\
\text { Project Savings, by } \\
\text { Line Item }\end{array}$ \\
\hline TOTAL Project Implementation cost & & $\$ 174,465$ & & \\
\hline Total Annual costs $\&$ savings & $\$-$ & $\$(41,077)$ & $\$ 74,957$ & $\$ 116,034$ \\
\hline
\end{tabular}

\section{ROI for brass direct sales}

The groupings of spreadsheets in Table A8 represent the ROI and supporting calculations for direct sales of brass.

Table A8. ROI brass direct sales (ERDC-CERL).

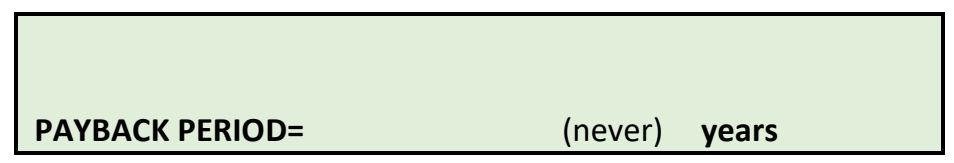

\begin{tabular}{|c|c|c|c|}
\hline & $\begin{array}{l}\text { \$ Current } \\
\text { Practice }\end{array}$ & \$ New option & $\begin{array}{l}\text { Net Annual } \\
\text { savings }\end{array}$ \\
\hline One time cost & & $\$ 275,747$ & \\
\hline Annual cost & $\mathrm{N} / \mathrm{A}$ & $\$ 5,811$ & $(\$ 5,811)$ \\
\hline
\end{tabular}

\begin{tabular}{|c|c|c|c|c|}
\hline Item & $\begin{array}{l}\text { \$ Current } \\
\text { Practice }\end{array}$ & $\begin{array}{l}\text { \$ Proposed } \\
\text { Project }\end{array}$ & $\begin{array}{c}\text { \$ Net Annual } \\
\text { Project Cost, by } \\
\text { Line Item }\end{array}$ & $\begin{array}{c}\text { \$ Net Annual } \\
\text { Project Savings, } \\
\text { by Line Item }\end{array}$ \\
\hline \multicolumn{5}{|l|}{ One-time costs for new option } \\
\hline $\begin{array}{r}\text { Capital purchase, } \\
\text { safety certification unit }\end{array}$ & & $\$ 146,054$ & & \\
\hline Labor to install $(40 \mathrm{hr})$ & & $\$ 2,400$ & & \\
\hline Connection to utilities, site & & $\$ 10,000$ & & \\
\hline $\begin{array}{r}\text { Staff time for coordination, contracting, } \\
\text { etc. (three weeks) }\end{array}$ & & $\$ 9,600$ & & \\
\hline $\begin{array}{r}\text { Training and travel (four people, two } \\
\text { weeks TDY) }\end{array}$ & & $\$ 34,400$ & & \\
\hline Purchase brass deformer & & $\$ 73,293$ & & \\
\hline \multicolumn{5}{|l|}{ Annualized costs } \\
\hline \multicolumn{5}{|l|}{ Labor } \\
\hline DPW Staff labor (2 weeks) & N/A & $\$ 6,400$ & $\$ 6,400$ & N/A \\
\hline
\end{tabular}




\begin{tabular}{|c|c|c|c|c|}
\hline Item & $\begin{array}{l}\text { \$ Current } \\
\text { Practice }\end{array}$ & $\begin{array}{l}\text { \$ Proposed } \\
\text { Project }\end{array}$ & $\begin{array}{l}\text { \$ Net Annual } \\
\text { Project Cost, by } \\
\text { Line Item }\end{array}$ & $\begin{array}{l}\text { \$Net Annual } \\
\text { Project Savings, } \\
\text { by Line Item }\end{array}$ \\
\hline $\begin{array}{r}\text { O\&M Labor, Gov't (two people, } 2 \text { weeks } \\
\text { per year) }\end{array}$ & $\mathrm{N} / \mathrm{A}$ & $\$ 9,600$ & $\$ 9,600$ & N/A \\
\hline Service calls & N/A & N/A & N/A & N/A \\
\hline Contractor labor & $\mathrm{N} / \mathrm{A}$ & $\mathrm{N} / \mathrm{A}$ & $\mathrm{N} / \mathrm{A}$ & N/A \\
\hline $\begin{array}{r}\text { Periodic training (one week training per } \\
\text { year, two people) }\end{array}$ & $\mathrm{N} / \mathrm{A}$ & $\$ 4,800$ & $\$ 4,800$ & N/A \\
\hline \multicolumn{5}{|l|}{ Parts } \\
\hline Consumables & $\mathrm{N} / \mathrm{A}$ & N/A & N/A & N/A \\
\hline Parts & $\mathrm{N} / \mathrm{A}$ & $\$ 5,000$ & $\$ 5,000$ & N/A \\
\hline \multicolumn{5}{|l|}{ Utilities } \\
\hline Electricity for deformer & N/A & $\$ 164$ & $\$ 164$ & N/A \\
\hline Propane for Safety Certifier & N/A & $\$ 1,320$ & $\$ 1,320$ & N/A \\
\hline Potable water & $\mathrm{N} / \mathrm{A}$ & N/A & N/A & N/A \\
\hline Sanitary sewer & $\mathrm{N} / \mathrm{A}$ & N/A & $\mathrm{N} / \mathrm{A}$ & N/A \\
\hline Liquid fuels & N/A & N/A & N/A & N/A \\
\hline \multicolumn{5}{|l|}{ Waste } \\
\hline Solid waste management and disposal & $\mathrm{N} / \mathrm{A}$ & N/A & N/A & N/A \\
\hline Universal waste handling and disposal & $\mathrm{N} / \mathrm{A}$ & N/A & N/A & N/A \\
\hline Hazardous waste handling and disposal & $\mathrm{N} / \mathrm{A}$ & $\mathrm{N} / \mathrm{A}$ & N/A & N/A \\
\hline \multicolumn{5}{|l|}{ Environmental Compliance } \\
\hline Staff time for permitting & $\mathrm{N} / \mathrm{A}$ & $\mathrm{N} / \mathrm{A}$ & $\mathrm{N} / \mathrm{A}$ & N/A \\
\hline Fees & N/A & N/A & N/A & N/A \\
\hline \multicolumn{5}{|l|}{ Vehicle Use (cost to gov't) } \\
\hline Fuel cost & $\mathrm{N} / \mathrm{A}$ & $\mathrm{N} / \mathrm{A}$ & $\mathrm{N} / \mathrm{A}$ & N/A \\
\hline Security & $\mathrm{N} / \mathrm{A}$ & $\mathrm{N} / \mathrm{A}$ & N/A & N/A \\
\hline Pavement maintenance & N/A & N/A & N/A & N/A \\
\hline \multicolumn{5}{|l|}{ Other } \\
\hline $\begin{array}{r}\text { Income from Brass sales } 12,000 \\
\text { pounds/yr., \$1.75/pound) }\end{array}$ & $\mathrm{N} / \mathrm{A}$ & $\$(21,473)$ & $\mathrm{N} / \mathrm{A}$ & $\$ 21,473$ \\
\hline misc. 2 & N/A & N/A & N/A & N/A \\
\hline Misc. 3 & $\mathrm{~N} / \mathrm{A}$ & N/A & N/A & N/A \\
\hline
\end{tabular}




\begin{tabular}{|c|c|c|c|c|}
\hline Item & $\begin{array}{l}\text { \$Current } \\
\text { Practice }\end{array}$ & $\begin{array}{c}\text { \$ Proposed } \\
\text { Project }\end{array}$ & $\begin{array}{c}\text { \$ Net Annual } \\
\text { Project Cost, by } \\
\text { Line Item }\end{array}$ & $\begin{array}{c}\text { \$ Net Annual } \\
\text { Project Savings, } \\
\text { by Line Item }\end{array}$ \\
\hline Misc. 4 & N/A & $\mathrm{N} / \mathrm{A}$ & $\mathrm{N} / \mathrm{A}$ & $\mathrm{N} / \mathrm{A}$ \\
\hline Misc. 5 & N/A & $\mathrm{N} / \mathrm{A}$ & $\mathrm{N} / \mathrm{A}$ & N/A \\
\hline TOTAL Project Implementation Cost & & $\$ 275,747$ & & \\
\hline Total Annual Cost \& Savings & \$- & $\$ 5,811$ & $\$ 27,284$ & $\$ 21,473$ \\
\hline
\end{tabular}

Figure A1. Safety certification machine (GSA Advantage).

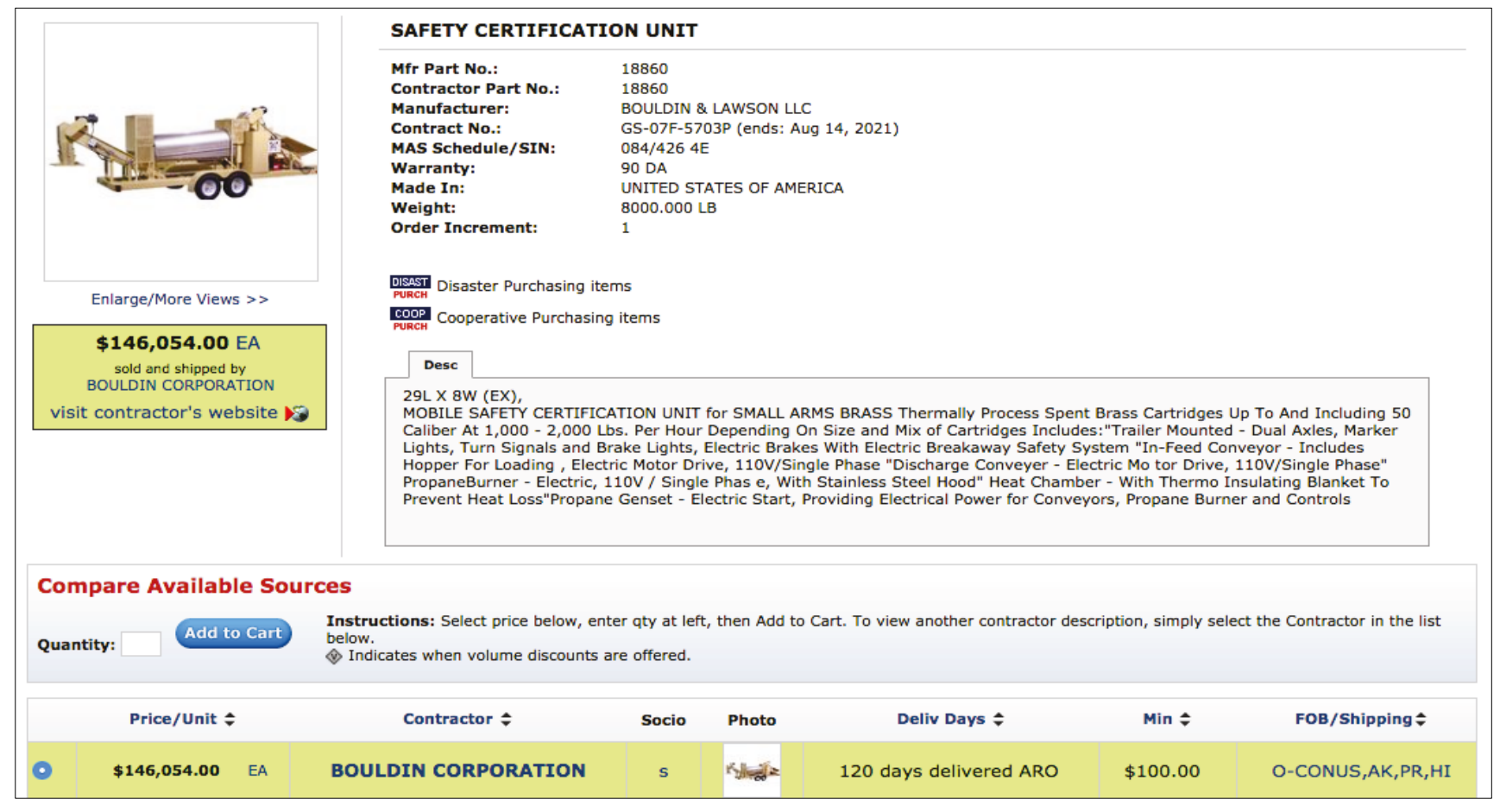


Figure A2. Brass deformer (GSA Advantage).

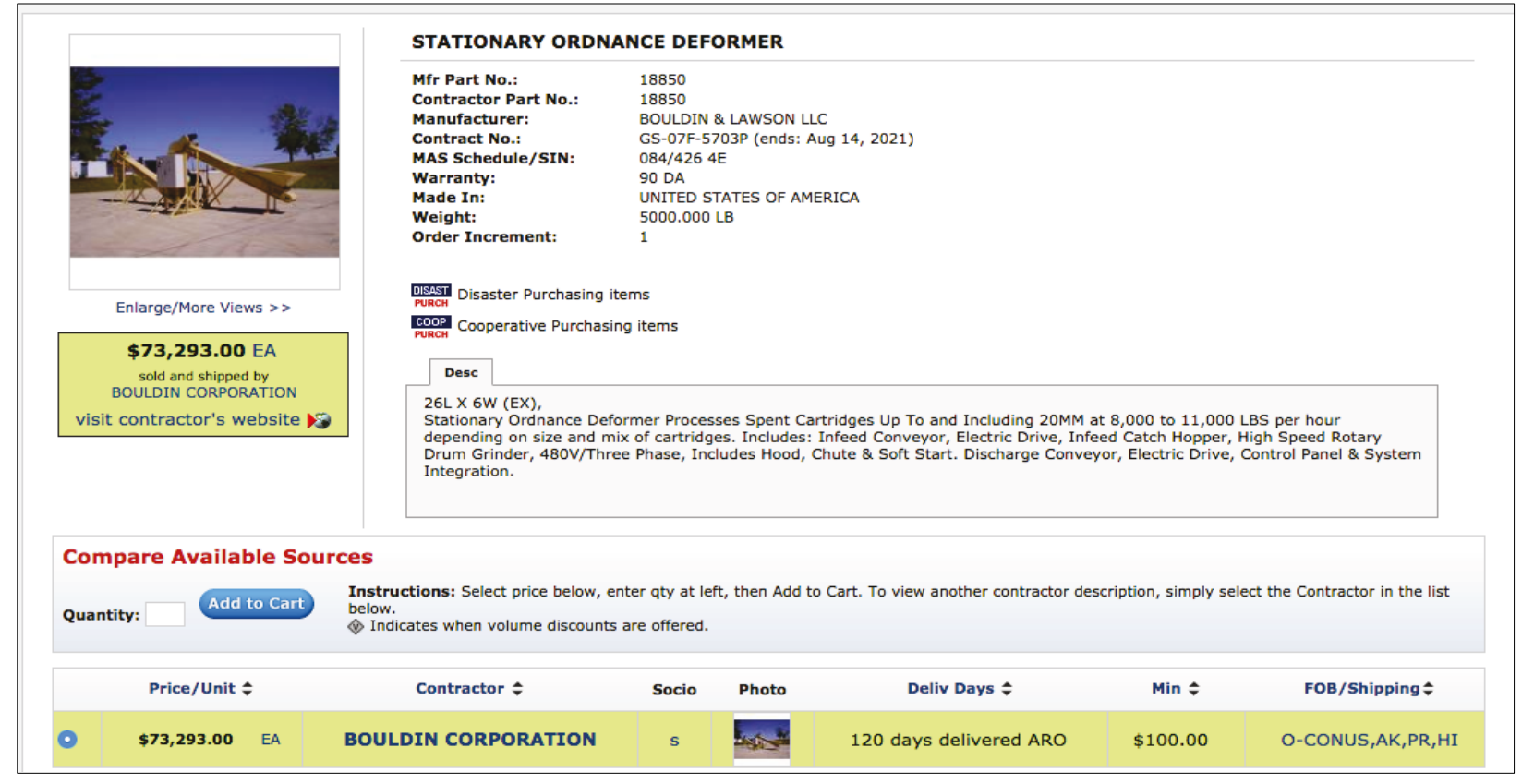




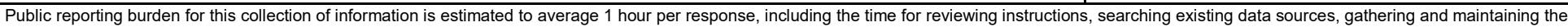

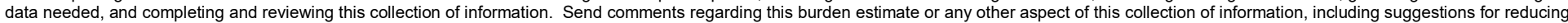

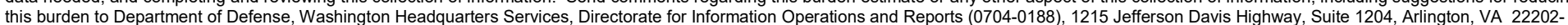

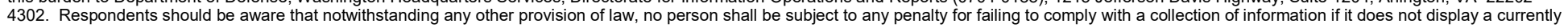
valid OMB control number. PLEASE DO NOT RETURN YOUR FORM TO THE ABOVE ADDRESS

\section{REPORT DATE (DD-MM-YYYY) \\ September 2018}

Feasibility Study of a Qualified Recycling Program at Fort Huachuca, Arizona
4. TITLE AND SUBTITLE

3. DATES COVERED (From - To)

5a. CONTRACT NUMBER

5b. GRANT NUMBER

5c. PROGRAM ELEMENT NUMBER

\section{5d. PROJECT NUMBER}

P2 454201

5e. TASK NUMBER

\section{5f. WORK UNIT NUMBER}

\section{PERFORMING ORGANIZATION NAME(S) AND ADDRESS(ES)}

U.S. Army Engineer Research and Development Center (ERDC)

Construction Engineering Research Laboratory (CERL)

PO Box 9005

Champaign, IL 61826-9005

\section{SPONSORING / MONITORING AGENCY NAME(S) AND ADDRESS(ES)}

10. SPONSOR/MONITOR'S ACRONYM(S)

U.S. Army Garrison

14 Rhea Avenue

Fort Huachuca, AZ 85613-7004 NUMBER(S)

\section{DISTRIBUTION / AVAILABILITY STATEMENT}

Approved for public release; distribution is unlimited.

\section{SUPPLEMENTARY NOTES}

\section{ABSTRACT}

This document details the processes and procedures that Fort Huachuca, Arizona, must follow to establish a qualified recycling program (QRP). QRP programs help installations meet Army goals to minimize waste disposal costs and increase waste diversion rates. This document will outline three optimizing recycling collection strategies: (1) collection from all buildings, (2) collection by building type, and (3) collection only from specific buildings. In an effort to help Fort Huachuca determine the feasibility of establishing a recycling and QRP program, these scenarios are formulated according to three main recycling and QRP program goals: income, diversion, and a combination of both income and diversion. Each scenario is presented with an economic analysis. Wherever feasible, the QRP is an effective mechanism, and it offers a cost-effective way to use funds from the sale of recyclables to support a recycling program and various morale, welfare, and recreation efforts.

\section{SUBJECT TERMS}

Military bases--Waste disposal, Military bases--Recycling (Waste, etc.), Fort Huachuca (Ariz.), Qualified recycling program (QRP)

16. SECURITY CLASSIFICATION OF:
\begin{tabular}{l|l|l|}
\hline $\begin{array}{c}\text { a. REPORT } \\
\text { Unclassified }\end{array}$ & $\begin{array}{c}\text { b. ABSTRACT } \\
\text { Unclassified }\end{array}$ & $\begin{array}{c}\text { c. THIS PAGE } \\
\text { Unclassified }\end{array}$ \\
\hline
\end{tabular}

17. LIMITATION
OF ABSTRACT
UU

18. NUMBER OF PAGES

100 19a. NAME OF RESPONSIBLE PERSON

19b. TELEPHONE NUMBER (include area code) 